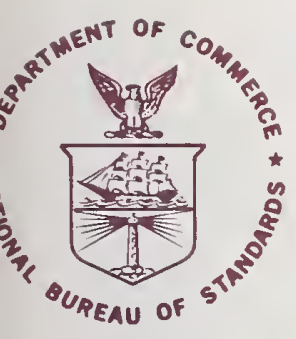

NBS TECHNICAL NOTE $\mathbf{8 8 5}$

U.S. DEPARTMENT OF COMMERCE / National Bureau of Standards

A Technical Review of the

Nicaraguan Building Regulatory System

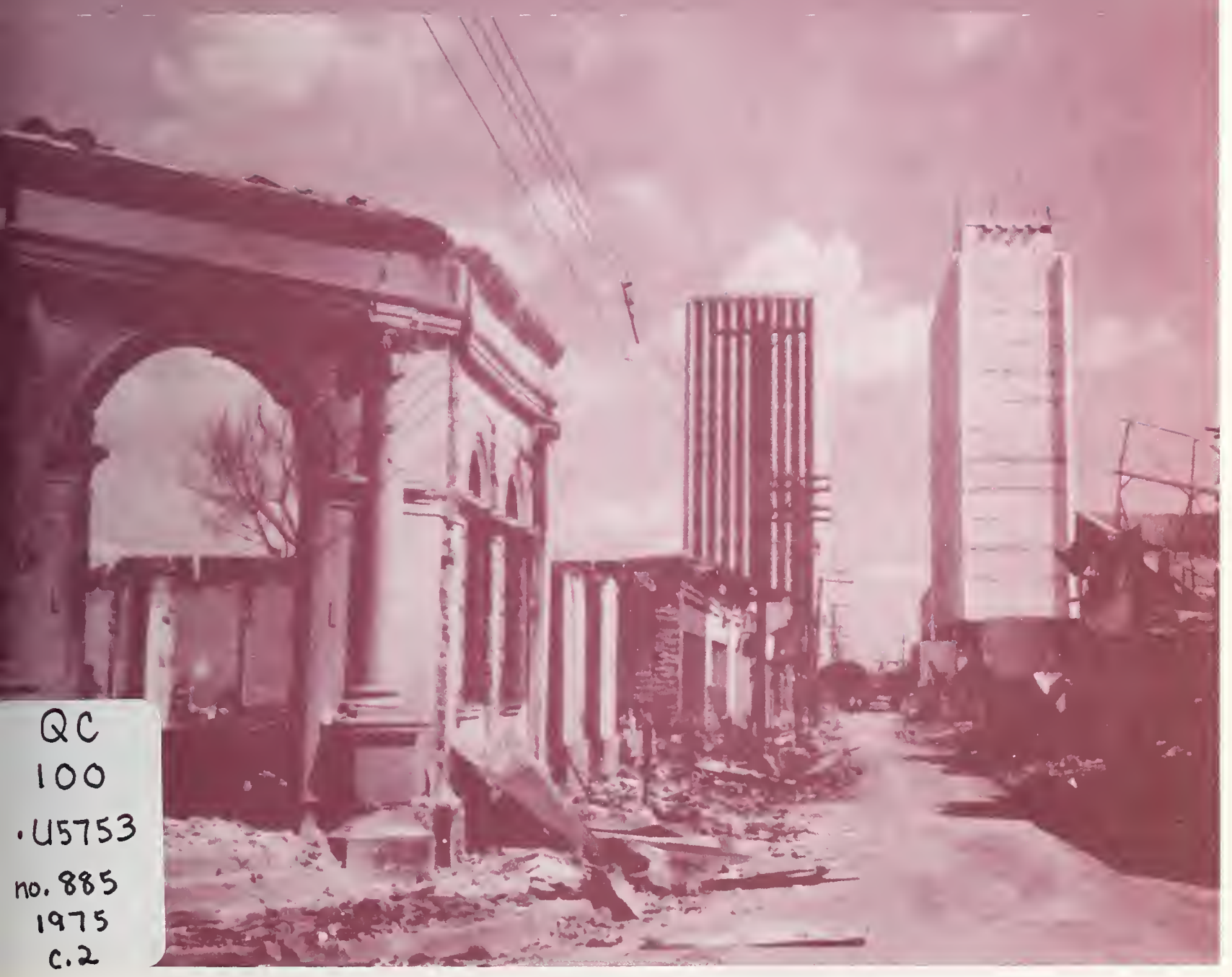




\section{NATIONAL BUREAU OF STANDARDS}

The National Bureau of Standards * was established by an act of Congress March 3, 1901. The Bureau's overall goal is to strengthen and advance the Nation's science and technology and facilitate their effective application for public benefit. To this end, the Bureau conducts research and provides: (1) a basis for the Nation's physical measurement system, (2) scientific and technological services for industry and government, (3) a technical basis for equity in trade, and (4) technical services to promote public safety. The Bureau consists of the Institute for Basic Standards, the Institute for Materials Research, the Institute for Applied Technology, the Institute for Computer Sciences and Technology, and the Office for Information Programs.

THE INSTITUTE FOR BASIC STANDARDS provides the central basis within the United States of a complete and consistent system of physical measurement; coordinates that system with measurement systems of other nations; and furnishes essential services leading to accurate and uniform physical measurements throughout the Nation's scientific community, industry, and commerce. The Institute consists of a Center for Radiation Research, an Office of Measurement Services and the following divisions:

Applied Mathematics - Electricity - Mechanics - Heat - Optical Physics - Nuclear

Sciences $^{2}$ - Applied Radiation ${ }^{2}$ - Quantum Electronics ${ }^{3}$ - Electromagnetics ${ }^{3}$ - Time and Frequency ${ }^{3}$ - Laboratory Astrophysics ${ }^{3}$ - Cryogenics ${ }^{3}$.

THE INSTITUTE FOR MATERIALS RESEARCH conducts materials research leading to improved methods of measurement, standards, and data on the properties of well-characterized materials needed by industry, commerce, educational institutions, and Government; provides advisory and research services to other Government agencies; and develops, produces, and distributes standard reference materials. The Institute consists of the Office of Standard Reference Materials and the following divisions:

Analytical Chemistry — Polymers - Metallurgy — Inorganic Materials — Reactor

Radiation - Physical Chemistry.

THE INSTITUTE FOR APPLIED TECHNOLOGY provides technical services to promote the use of available technology and to facilitate technological innovation in industry and Government; cooperates with public and private organizations leading to the development of technological standards (including mandatory safety standards), codes and methods of test; and provides technical advice and services to Government agencies upon request. The Institute consists of a Center for Building Technology and the following divisions and offices:

Engineering and Product Standards - Weights and Measures - Invention and Innovation - Product Evaluation Technology — Electronic Technology - Technical Analysis

- Measurement Engineering - Structures, Materials, and Life Safety ${ }^{4}$ - Building

Environment ${ }^{4}$ - Technical Evaluation and Application ${ }^{4}$ - Fire Technology.

THE INSTITUTE FOR COMPUTER SCIENCES AND TECHNOLOGY conducts research and provides technical services designed to aid Government agencies in improving cost effectiveness in the conduct of their programs through the selection, acquisition, and effective utilization of automatic data processing equipment; and serves as the principal focus within the executive branch for the development of Federal standards for automatic data processing equipment, techniques, and computer languages. The Institute consists of the following divisions:

Computer Services - Systems and Software - Computer Systems Engineering — Information Technology.

THE OFFICE FOR INFORMATION PROGRAMS promotes optimum dissemination and accessibility of scientific information generated within NBS and other agencies of the Federal Government; promotes the development of the National Standard Reference Data System and a system of information analysis centers dealing with the broader aspects of the National Measurement System; provides appropriate services to ensure that the NBS staff has optimum accessibility to the scientific information of the world. The Office consists of the following organizational units:

Office of Standard Reference Data - Office of Information Activities - Office of Technical Publications - Library - Office of International Relations.

${ }^{1}$ Headquarters and Laboratories at Gaithersburg. Maryland, unless otherwise noted; mailing address Washington, D.C. 20234.

${ }^{2}$ Part of the Center for Radiation Research.

${ }^{3}$ Located at Boulder, Colorado 80302.

- Part of the Center for Building Technology. 


\section{A Technical Review of the Nicaraguan Building Regulatory System}

Richard N. Wright

Institute for Applied Technology

Center for Building Technology

National Bureau of Standards

Washington, D.C. 20234

and

Ing. Atilano Lamana

Instituto De Investigaciones y Ensayes De Materiales

Universidad De Chile

Plaza Ercilla 893 Casilla

1420 Santiago, Chile

Sponsored by

The Organization of American States

The United States Agency for International Development

U.S. Department of State

and

The National Bureau of Standards

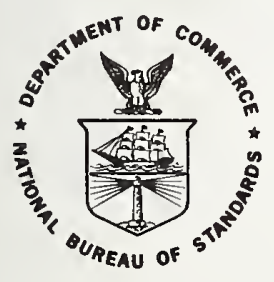

U.S. DEPARTMENT OF COMMERCE, Rogers C.B. Morton, Secretary James A. Baker, III, Under Secretary

Dr. Betsy Ancker-Johnson, Assistant Secretary for Science and Technology

NATIONAL BUREAU OF STANDARDS, Ernest Ambler, Acting Director

Issued October 1975 
Library of Congress Catalog Card Number: 75-600078

\section{National Bureau of Standards Technical Note 885}

Nat. Bur. Stand. (U.S.), Tech. Note 885, 85 pages (Oct. 1975)

CODEN: NBTNAE 
1. Introduction .................. 1

2. Lessons from the 1972 Managua Earthquake . . . . . . . . 2

3. Building Regulatory System ............ 2

4. Nicaraguan Building Code . . . . . . . . . . . . 5

4.1 Emergency Code . . . . . . . . . . . . 5

4.2 Cartilla de Construccion ............5

4.3 Draft Code . . . . . . . . . . . . 6

4.4 General Recommendations . . . . . . . . . 6

5. Review of Designs ................ 7

6. Inspection of Construction ............ . 8

7. Organization of the National Laboratory and Standards

Activities.................. . . . . .

7.1 Relation Between a National Laboratory and Standards

Activities ................ . . 9

7.2 Functions of the Nicaraguan Building Institute . . . 10

7.3 Relations with the National University . . . . . .11

7.4 Relations with Private Laboratories . . . . . . . 12

8. Organization and Objectives of the Laboratory . . . . . 12

9. Educational Programs . . . . . . . . . . . 15

10. Summary ................... . . . . . . .

11. References ................... . . 18

APPENDIX A Itinerary and Contacts in Field Investigations . . .19

APPENDIX B Building Regulation for Earthquake Resistant

Construction .............. . . 24

APPENDIX C Housing Performance in the 1972 Managua Earth-

quake................. . . 42 

Richard N. Wright

and

Atil lano Lamana

\section{Abstract}

This report on the Nicaraguan Building Regulatory System has been prepared under the auspices of the Organization of American States and the United States Agency for International Development. It presents an overview of the building regulatory system in Nicaragua; its activities in review of designs, issuance of building permits, inspection of construction, control of quality of materials, and issuance of occupancy permits. The technical bases for these activities are the building code and standards, the laboratory facilities for control of the quality of building materials, and the processes for development and application of codes and standards. Recommendations address the status and development of this system and its technical bases.

The 10sses in the December 23, 1972, Managua Earthquake provided dramatic evidence of the need for effective implementation of good building standards. Repetitions of these tragic losses elsewhere in Nicaragua and in a reconstructed Managua are certain unless a good building code is developed and adopted, its use and design by architects and engineers enforced by careful review of designs, and the implementation of these designs by the builders assured by inspection of construction and testing of building materials. A summary and critical review of U.S. building regulatory practices for areas with severe natural hazards is presented in Appendix B for guidance in building regulatory system planning and development. A survey of housing performance in Managua is presented in Appendix $C$ to illustrate that earthquake resistant construction is feasible and economical for Nicaragua and other nations with comparable resources.

Keywords: Architecture; building; building codes; building design; disaster mitigation; earthquakes; engineering; environmental hazards; housing; inspection and testing; safety.

\section{Introduction}

This study of the Nicaraguan Building Regulatory System was sponsored by the Organization of American States (OAS) and the United States Agency for International Development (AID). Major programs of reconstruction were made necessary by the December 23, 1972 Managua earthquake. An effective building regulatory system is needed to assure the public health, safety, and welfare in the reconstructed city, and to achieve these objectives economica $11 \mathrm{y}$.

Ing. Atilano Lamana, who led the study team and represented OAS, has investigated the effects on buildings of many Chilean earthquakes, participated in the development of Chilean building standards, and heads the Chilean national laboratory for building technology. Dr. Richard N. Wright, who represented AID, was leader of the first U.S. building investigation team to reach Managua following the earthquake and is active in the ongoing U.S. program to revise seismic design standards.

The writers comprised a joint OAS/AID team which worked in Managua from July 9-21 and July 30-August 8, 1973, and in Mexico and Guatemala from July 23-30, 1973. The team consulted with Nicaraguan government officials, the professional and construction communities in Nicaragua and standards authorities 
in Mexico, Guatemala, and the United States. An itinerary of these activities appears in Appendix $A$. The recommendations and conclusions presented herein, are based on these consultations, direct observations, and the references cited from other investigations.

Many persons have assisted the writers in the collection and evaluation of the information presented here. They thank each of the persons noted in Appendix A for their help in the work.

\section{Lessons from the 1972 Managua Earthquake}

Most damages in the 1972 Managua earthquake appeared to result from deficiencies in building practices, deficiencies which have been exhibited many times before in previous earthquakes, which would be avoided by implementation of appropriate seismic provisions in design and construction. However, in spite of the earlier disastrous earthquake of 1931, Managua did not employ a building code with seismic design requirements appropriate to its earthquake risk; it enforced only zoning regulations. Furthermore, it did not have a building regulatory system capable of effective implementation of building code provisions.

The measured acceleration of $0.39 \mathrm{~g}[1]]^{1 /}$ of the Managua earthquake, ranks among the highest recorded, and accelerations probably were greater in the center of the city. However, the successful performance of many buildings in the earthquake prove that it is feasible and economical to resist earthquake motions of such intensity. The modern buildings of Managua, taller than five stories, were generally designed and constructed in accord with the earthquake resistant practices of the western United States. In accord with the stated objectives of the provisions [2], in this severe earthquake none of these buildings collapsed. Property damages in a number of the taller buildings were severe; however, it is widely recognized [3] that property damages can be much reduced for $1 \mathrm{ittle}$ or no additional investment by appropriate design and choice of structural type. The very limited damages to nonstructural systems, furnishings, and equipment in the Banco de America and the ENALUF administration building are examples from the Managua earthquake of this type of damage control.

Housing developments throughout the city show variation from very little to very substantial damages; this is more a result of the quality of design and construction than of the specific location. Since all these developments were economically practicable, they provide an excellent view of both good and bad practices for earthquake resistant buildings. The performance of these housing developments is described in Appendix C to emphasize that earthquake resistant buildings are feasible and economical for Managua.

\section{Building Regulatory System}

This section presents an overview of the building regulatory system and the interrelationships between its elements to provide a framework for discussions of these elements in Nicaragua. A more detailed view of the organization and administration of building regulatory systems is given in Appendix B.

The objectives of a building regulatory system usually include the protection of the safety, health, and property of the citizens of the political unit to which the building regulatory system pertains. Each person involved in the building process: owner, planner, designer, manufacturer, builder, and occupant has his responsibility and role. The purpose of the building

Numbers in brackets refer to entries in the list of references. 
regulatory system is to assure clear definition of each role and to make appropriate checks to assure that each person with a role is capable of meeting his responsibilities and carries them out fajthfully.

Nicaragua has very limited experience with a building regulatory system; most of this experience has been gained since the 1972 earthquake. Prior to the earthquake, building regulations dealt only with land use and zoning. There was no building code covering the practices of design and construction or the quality of materials to be employed in construction. On January 24, 1973, Nicaragua decreed an emergency code [4]. This code is restricted in coverage to the earthquake resistant design of building structures and applies only in the city of Managua. It speaks to design, construction, and control of the quality of building material. It calls for review of plans and inspection of construction to assure implementation of the code provisions.

In June 1973, the Oficina Nacional de Urbanismo published a Cartilla de construccion. This is a detailed guide to the construction of houses of one story which are cunstructed under the supervision of a builder without participation of professional designers. The Cartilla covers the preparation of materials and the details of their employment in the most common types of buildings.

The building code was drafted rapidly to meet emergency needs; the oficina Tecnica de Construccion Sismica Nacional was created within the Oficina Nacional de Urbanismo of the Ministerio de Obras Publicas to: review plans, designs, and calculations; review existing structures damaged in the earthquake; inspect and control materials used in construction; supervise construction and insure that structures are constructed in accordance with plans; and conduct a number of longer range activities concerned with development of improved building codes and practices. It is to be expected that problems would be encountered with the emergency code and in its rapid implementation.

Prompt and effective resolution of these problems is important to avoid a crisis in the building regulatory system which could either slow the reconstruction of Managua and the further development of Nicaragua as a whole, or else cause an end to efforts to effectively regulate the building process. The latter would mean that Managua and other areas of Nicaragua could expect to endure disasters comparable to the 1972 earthquake again and again in the future.

The reference documents of the building regulatory system are the building code and the standards to which it refers. The building code is the legal document requiring specific acts on the part of owners, designers, builders, and occupants. The standards are technical documents providing specific definitions of the qualities called for in the code. Standards may describe design procedures such as those for evaluating the resistance of a beam, materials such as the definition of a type of cement, and test methods such as the procedure for measuring the strength of concrete. 0ther important reference documents are the aids to various participants in the building process. These may include handbooks for designers, inspectors, craftsmen, etc., in their interpretation and application of the code and standards.

Building codes and the associated standards are not constant either in space or in time. In space, they must be adapted to conditions of practice in individual areas, to the objectives individual governments set for their buildings' performance, to the nature of the materials available for buildings, and to the skills available in the design and construction professions and crafts. In time, they change as new knowledge allows improvements in practices, codes and standards, as the requirements of the public change, or as the competences of the designers and builders develop. Thus, the develop- 
ment and maintenance of building codes and standards is a major activity within the building regulatory system. In Nicaragua which has a newly created and provisional building regulatory system, this is a particularly undeveloped area of the system. There are few people in Nicaragua experienced in development or maintenance of building codes. An institute for building standards is needed for the development and maintenance of standards and for technical support for the process of the development and implementation of the legal building code.

Laboratories are essential to evaluate and control the quality of building materials. Many laboratories are involved; industrial laboratories for quality control by the manufacturer, private laboratories to provide testing services for professional architects and engineers, and contract services to governmental agencies, and the national laboratory responsible for direct quality control in selected areas, and for accreditation of the industrial and private laboratories.

A broad range of education programs are essential for support of an effective building regulatory system. Continuing professional education is needed for the architects and engineers in Nicaragua; immediately to bring them abreast of the latest and best practices for earthquake resistant design so important for the reconstruction of Managua; in the long range to keep them up-to-date in building technology which is a broad applied field changing with and benefiting from advances in most disciplines of science and technology. However, the most critical need for education in Nicaragua appears to 1 ie in the subprofessional areas for craftsmen such as welders, masons, and plumbers, foremen and supervisors, draftsmen, inspectors, and laboratory technicians. The high productivity needed in the construction industry of Managua for the rebuilding effort will be possible only if these subprofessionals can carry out effectively their roles in the building process.

Nicaragua now has an embryonic building regulatory system established in response to the emergency created by the December 23, 1972 earthquake. One major problem with this system is its scope. It pertains only to Managua and covers only the design of the structural system for earthquake loading. It is important for the safety and economic well being of the citizens of Nicaragua that the activities of this system be expanded to cover all building construction in Nicaragua and all significant aspects of the performance of buildings.

The growth of this system must be well planned to avoid assumption of responsibilities which cannot be carried out. This would result in a loss of construction productivity, an increase in cost, and the loss of confidence of the citizens of Nicaragua in the ability of their government to regulate construction of buildings. Experience [5] indicates that the ideal organization of the building regulatory system provides:

- focus of all code enforcement activities in one agency

o that the chief of this agency have direct responsibility to the chief executive of the level of government responsible for building regulations

o that code enforcement be the sole function of this agency

The organization of the Nicaraguan building regulatory system within the oficina Nacional de Urbanismo is in accord with the first and third of these points. Its location within the Ministerio de Obras Publicas gives that Minister both building program responsibilities, such as the construction of highways and public buildings, and the regulatory responsibility. The building regulatory system would have fewer potential conflicts of interest if it were made a separate agency within the executive branch of the Nicaraguan government. 


\section{Nicaraguan Building Code}

The building code is a legal document requiring that design and construction be in accord with the specifically stated provisions or explicitly cited standards. The status of and the needs for the building code and its associated standards in Nicaragua were discussed with officials of the Ministry of Public Works, members of the design professions and the builders. Discussions dealt with the texts of the January 1973 emergency code and the draft of the proposed building code.

\subsection{Emergency Code}

The emergency code, which was developed in January 1973 by Nicaraguan engineers working with foreign experts, applies explicitly only to structural design for seismic loads. That is, it does not regulate the design of elements of the building other than the structural system and regulates the design of the structural system only for earthquake loadings. Thus, a building in conformance with the emergency code could be functionally quite unserviceable, unsafe from hazards such as fire, and lacking in adequate structural capacity for the intended purpose. The Nicaraguan Seismic Code Review Committee feels the code is serving reasonably well for earthquake resistant design. After discussions with the Seismic Code Review Committee and members of the Nicaraguan design professions, the writers believe that the seismic provisions of the emergency code have the following deficiencies:

- Geological evidence suggests that all of Pacific Nicaragua (the Nicaraguan graben and coastal range) is exposed to a degree of seismic hazard comparable to that of Managua. Therefore, emergency code provisions should be applied to buildings throughout this area.

- Article 33 refers only generally to the requirement of exercising strict control on the quality of materials and procedures of construction. Because of the vagueness of this statement, no systematic testing is conducted to control the quality of materials used in repairs or new construction. Throughout the code, standards must be referred to which call for explicit control of the quality of materials and procedures of construction, and the code itself must call explicitly for enforcement of these quality control procedures.

- The strength required for masonry units and mortar in Article 26 appears too low while the allowable unit stresses appear too high; this amounts to a compounded infringment upon the normal factor of safety.

o The standards referred to in the emergency code do not cover light gauge steel and timber construction which are prevalent in Managua.

- An explanatory commentary, design manuals and design examples are available only for the provisions of the emergency code which use widely recognized U.S. standards.

o It refers to design standards of United States; use of these standards written in English with the U.S. system of units, has been difficult for some Nicaraguan designers.

\subsection{Cartilla de Construccion}

The Cartilla de Construccion is a handbook of construction for nonprofessionals such as foremen and small contractors. These persons, working without professional design assistance, are responsible for approximately 80 percent of the housing units in Managua. The Cartilla which was issued in June 1973, has been very helpful to the intended users and to subprofessional building inspectors. 


\subsection{Draft Code}

The draft proposed code was submitted for review of the Nicaraguan Seismic Code Review Committee in May 1973 by the Secretary of Public Works of Mexico. The draft was prepared by a group in the National University of Mexico working under subcontract with the Mexican consulting firm DEPLAN which is the contractor for this work to the Mexican Secretary of Public Works. Discussions with the Mexican group which drafted the code, indicate that it is very closely based on a new code for the Federal District of Mexico which this group is also preparing.

The scope of the proposed code is limited to design of the structure; it does account systematically for all types of loading on the structure. It is indicated that the strategy for this code could be applied to all aspects of buildings and the structural loading provisions generalized so as to allow the code to be applied throughout Nicaragua.

Based on discussions with the Nicaraguan Seismic Code Review Committee and the Mexican group which drafted the code, the writers believe:

- The proposed code employs an advanced philosophy of structural safety and presents relatively novel standards for implementation of this philosophy. At present, the proposed code does not contain a commentary explaining its provisions in detail; neither are design aids or examples available to assist Nicaraguan engineers in understanding and implementing the philosophy and standards.

- The new code provisions have not been used enough in practice to assure that they are complete, correct, and unambiguous.

- Early implementation of the proposed code in Nicaragua would be difficult since Nicaraguan designers would have to learn to understand and apply new techniques at a time when they are under extreme time pressures to meet needs for repairs and replacement of earthquake damaged buildings.

- The proposed code does not provide standards for light guage steel and timber construction; these are extensively used materials in Managua.

The draft code is a promising forward step in structural design standards. Mexican experience with its use will correct problems that may exist in the draft and lead to the development of the necessary design aids. It promises to provide a major resource for the development of a Nicaraguan building code.

\subsection{General Recommendations}

The process of development of a new Nicaraguan building code cannot be seen as an emergency activity. Code development is a process which requires substantial inputs from all segments of the building community (designers, building regulatory agencies, manufacturers, and builders) and thorough study to assure that an appropriate balance is achieved between risks to public health, safety, and property and the investments required to reduce these risks. This suggests that several years should be allowed for development of a new Nicaraguan building code, and that the process of development should take full advantage of parallel activities in Mexico, the United States, and other countries of the world.

Nicaraguan building codes and standards must have substantial inputs from the Nicaraguan building community to assure their effective applicability in Nicaragua. As discussed in more detail elsewhere in this report, it is recommended that the code and standard development activities become a responsibility of a Nicaraguan institution concerned with building standards. An immediate activity of this institution of building standards 
should be the amendment of the emergency code to remedy al ready identified defects.

The process of development of a new Nicaraguan building code may be inappropriate for Nicaragua to undertake alone. It is a major technical effort. Since conditions of service, natural hazards and practices of the building community are closely related throughout Central America, it appears appropriate to explore an appropriate international organization for a code development process applicable throughout Central America. This also is recommended by the second Central American Congress on Earthquake Engineering held in San Jose, Costa Rica, August 2-4, 1973.

\section{Review of Designs}

Review of designs is a major element in the building regulatory system. It includes review of design calculations, plans for the building, and the specifications governing the materials and fabrication to assure that the projected building is designed in accord with the building regulations.

Review of projects costing more than Cordobas 20,000 ( $\$ 2,900)$ is conducted in the National Technical office of Seismic Construction. The status of this office's review of designs on July 19, 1973 amounted to 50 projects awaiting review, many for the second time, with reviews completed at a rate of approximately 15 per week. This indicates an average waiting period of three weeks; some members of the Nicaraguan professional community said that their projects have taken two-three months for completion of reviews.

At the time of the investigation, review of designs had been conducted in Nicaragua for only six months. This was a time of emergency in the preparation of building designs; it was certain there would be problems with the process. The reviewers stated that many plans and calculations were incomplete, the work was not organized systematically, it is difficult to determine what assumptions were made, where numbers were taken from, and where they were to be used. Some professional practitioners said that the review was overdetailed, most calculations were recomputed, elements were redesigned in the review, and, therefore, the reviewers may appear co-responsible for the design. These problems occurred with a work load which was mostly repairs and designs for buildings of one and two stories. They were expected to become worse when the redevelopment plans were defined and more substantial projects were designed.

The office had problems with the turnover of professional staff who find more attractive employment in design practice after learning to review efficiently. It was also noted that for some buildings, work started before obtaining a permit, occupancy was attempted without a permit, and attempts were made to use influence to obtain waivers of the normal procedures of review and inspection.

The writers consider the objective in review of the design to assure that the designs have the proper scope and that the designer is competent for the work he has undertaken. To assure proper scope, the reviewer must see that the plans describe the intended building in sufficient detail, that the builder can understand the intention of the designer, that the calculations consider all the code requirements for the performance of the building which may include emergency exits, resistance to earthquake loading, resistance to wind loading, etc., and that the specifications developed for the job cover the required factors for control of the quality and fabrication of materials. The competence of the designers is assured by systematic spot checking of typical calculations to see that they are carried out correctly. It is not appropriate or feasible to redesign the structure by duplicating, in its entirety, the work of the designer. An efficient review process, which is in the interests of the public and the designer, is possible only if the submission of the design is wellorganized so that 
the reviewer can clearly trace the concepts of the designer through the plans, calculations and specifications.

Education of designers and reviewers can resolve these difficulties. The United Nations was considering a mission of foreign experts to work directly in Urbanismo giving on-the-job-training to their Nicaraguan colleagues. Such a program would provide additional help to accelerate the review process. An important part of such assistance should be the preparation of guides for submittal of projects for review. The experts should interact directly with the Nicaraguan professional firms to train them in presenting their work for review. A relatively, short-range program of this type, perhaps of less than one year in duration, should prevent a crisis in the Nicaraguan building regulatory system. Comparable expertise is available from other sources; in the United States alone model code agencies such as the International Conference of Building Officials or qualified consulting firms, which regularly provide both design services and contract review services to building regulatory agencies, also are capable of this assistance.

For the longer range, the Nicaraguan building regulatory system needs a professional development program to assure growth in the competence of its reviewers of design. Attractive salaries also are required so that highlyqualified personnel are not lured away to private practice.

There is an alternative which may reduce the problems arising from the conduct of all reviews within the Oficina Nacional de Urbanismo. When the building code is augmented by standards for the submittal and review of design, it will be possible to contract a substantial part of the review activities to properly qualified firms in the Nicaraguan professional community. Then the review staff of the Oficina Nacional de Urbanismo need be only a cadre, highly capable in review activities itself, but devoting much of its time to assuring that the contract review activities are properly conducted. There may be professional advantages to the contracting approach. Review of plans is a very important professional activity, but a career of nothing but review of plans is not attractive to most professionals with the necessary capabilities. A conflict of interest may exist if a member of the review staff of Urbanismo works part-time for a designer, whose work he must, from time to time review, in order to achieve a balance of his professional activities. However, there is no conflict of interest when a designer in a professional firm works sometimes on review.

Another problem in the review of designs was noted. Some Nicaraguan governmental agencies with construction responsibilities may be proceeding with design and construction practices which are not in accord with the building code. The Government of Nicaragua should have a policy on the codes and specifications to which governmental buildings will conform; the policy should make the Oficina Nacional de Urbanismo responsible for assuring compliance with the regulations.

\section{Inspection of Construction}

A system for inspection of construction by the building regulatory authorities has existed in Managua only since the establishment of the oficina Tecnica de Construccion Seismica Nacional following establishment of the emergency building code in January 1973. The inspection force in this office is headed by a professional engineer and employs nine, fifth-year engineering students as inspectors. Their work load in mid-July amounted to approximately 15 schools and 120 private buildings under construction. The Seccion de Permissos of the Oficina Nacional de Urbanismo also employs field inspectors to assure that construction and occupancy do not occur without permits. 
Discussions and field visits with the inspectors indicated that these students responded responsibly to the opportunity to participate directly in the emergency. They carried out their duties thoughtfully and in general, effectively. A manual and a check list for inspectors were needed to assure more systematic and uniform inspections. Apparently because of the vagueness of the emergency code, inspection did not include any quality control of materials or taking and testing of samples. Inspection activities were reported to be hampered by a shortage of vehicles, only three available to the group.

The activity of inspection is an essential part of the building regulatory system for all Nicaragua; it should be institutionalized by the development of a permanent body of inspectors. These should be skilled subprofessionals under the direction of a professional engineer. The inspectors should receive salaries adequate to allow them to concentrate on their responsibilities for the life safety and property of Nicaraguan citizens. The skills and salaries should be comparable to those for good construction foremen or laboratory technicians. Formal training programs are essential for qualification as a building inspector since the breadth of responsibility exceeds the knowledge of any construction craft or subprofessional skill in the background of a potential inspector. Furthermore, formal classes and examinations provide a useful third-party evaluation of his character and intelligence. The inspector must have legal authority to stop unacceptable work and must inspect for conformance with specifications for materials as well as the geometrical requirements of the plans.

A manual of practice and appropriate report forms must be prepared for inspectors. These are essential for guidance and consistency on the job and will be equally useful resources for the formal training program.

Experience [3] elsewhere indicates inspection by the building regulatory authority alone is not enough to assure proper quality of construction. The owner should be required to engage professional services for surveillance of construction as part of the professional services required for design. The designer is exceptionally well-qualified to recognize occurrence of conditions which were not anticipated in design and to assess the builder's implementation of plans and specifications. This surveillance should in no way reduce the builder's responsibility for compliance with the plans and specifications. Responsibility of both the designer and the building authority for inspection of construction provides additional assurance of compliance which has been shown effective by the good earthquake performance of California schools constructed under provisions of that state's Field Act.

There are also examples of poor performance of buildings for which the owner and builder was essentially one entity. For these situations, an especially stringent review of design and inspection of construction should be provided by the building regulatory authority at the expense of the owner-builder.

\section{Organization of the National Laboratory and Standards Activities}

7.1 Relation Between a National Laboratory and Standards Activities

Nicaragua's present problems in developing a building code are not of transient nature. A building code must be continually under revision; furthermore, it must be complemented by many standards. Therefore, a permanent office of standards is needed for this work. This organization would not develop a totally original building code and standards. Rather, it would coordinate the work for national adaptation of international standards and represent national interests in international standards activities. 
There are many advantages in adopting international standards. They include economy of effort in development of standards for national application, benefits from advances in international technology, and qualification of the national products for foreign trade. Therefore, it is recommended that this office of standards be closely related with ICAITI (Instituto Centro Americano de Investigacion y Tecnologia Industrial) and support it in the discussion and promotion of a building code and building standards for Central America.

A building code must account for local conditions of practice, as well as requiring technically sound uses of fundamental principles and methods of design. The properties of local building materials are of principal significance; the experimental information required to define these can be developed by a national laboratory for testing of materials. The work of this laboratory may be coordinated with foreign laboratories, especially those of Central America in connection with ICAITI, to plan joint investigations on problems of regional nature relevant to the development of a Central American building code.

However, it is not enough to have a building code; it also is necessary to provide for its enforcement. At present, enforcement lacks the support a national laboratory for testing of materials could provide in direct quality assurance and through accreditation of private laboratories.

Because these close relationships between the office of standards and the national laboratory are essential to their effectiveness, and to reduce their operational costs, it is proposed that they be integrated into one Nicaraguan Building Institute.

\subsection{Functions of the Nicaraguan Building Institute}

\section{The principal functions are:}

- Inspection of the private laboratories. The Institute shall provide accreditation of the private laboratories to give their tests legal standing. The Institute will exercise periodic inspection to assure the quality of equipment and testing procedures. For this function the Institute requires instruments and expert personnel for calibration of the private laboratories' equipment and evaluation of their procedures.

- Control of quality. The Institute will assess the quality of construction materials at their origin, before they are distributed for sale, for the protection of consumers including the smallest. This inspection will take place in the factory, quarry, or customs house, depending upon the source of the materials. This would be the means for control of factory-made products such as cement, 1 ime, gypsum, brick, blocks, pipes, floor tiles, asbestos cement, and lumber. The Institute also would analyze the sources of sand and gravel. Imported materials would be sampled at the customs house and tested in the laboratory. This control of quality may be extended to materials for export in order to guard the regulation of the nation's exports. The legal authority for any rejection of products would be held by appropriate governmental agencies which would act on the basis of the test reports provided by the Institute.

- Development of codes and standards. The Institute would participate actively in the development of codes and standards; its laboratory will give experimental support for their preparation. The laboratory will obtain statistics on the qualities of national materials from its functions in control of quality. These are vital information for classifying materials, determining their admissible applications and allowable stresses. The laboratory also may conduct research programs for specific studies related to standards. For example, at present there is need for a study of the shear strength of masonry walls made of the local materials (blocks, bricks, cement, lime, sand). 
- Evaluation and development. The Institute will carry out studies on new uses of local raw materials in construction, study possible improvements in the quality of present materials, test prefabricated elements to verify their design and fabrication, make experimental studies of connections, evaluate the various proposals in design competitions, etc.

o Dissemination of knowledge. The Institute will distribute pertinent knowledge, prepare recommended practices for construction whether original or in translations, organize talks and seminars, and prepare a catalog of the materials for which it maintains standards.

o Testing. The Institute, as the national laboratory, will provide services to the Ministry of Public Works in the development of specifications, studies of materials, and control of quality, thus amplifying the services which at present are concerned only with highways. The inspection services of building regulatory agencies may contract with the Institute for the testing of samples taken on the jobs.

- Education. The universities should have free access to this wellequipped laboratory to strengthen their programs of professional education. The facilities of the laboratory will be particularly useful in courses on materials and in the preparation of professional theses. The problems recognized in daily contact with the laboratory. work will encourage the students to select thesis topics of real national interest and contribute to their professional development. Also, the participation of the students in the work of the Institute will help it recognize the most capable when there is need to increase its professional staff.

For all these reasons, it appears necessary to locate the laboratory close to the two universities of Managua.

- Arbitration. The Institute can serve as the supreme technical authority in resolution of contractual problems.

- Training. The Institute can collaborate in the training of subprofessional technical personnel by making available its physical facilities and recommended practices.

\subsection{Relations with the National University}

In some countries, the laboratories of the engineering school of the national university function as the national laboratory. At first view, this would be a possible solution for Nicaragua; it is examined by an analysis of its advantages and disadvantages.

There are various factors favoring the concept as follows:

o The university constitutes an arbitrator with recognized independence of judgment and a high level of knowledge.

- A testing program for control of quality of materials gives the university extra financial resources which can support research.

o The availability of good laboratory equipment improves the educational resources available to the students.

- Control of quality of building materials in the universities gives the students contacts with practice comparable to those in a clinical hospital for a medical school. Also, the professors have available an excellent means for study of the nation's construction practices and the quality of its materials. They can give the students a realistic perspective of materials " performance by incorporating this knowledge in their lectures.

o Equipment in the laboratories also may be used in university research.

- The activities in control of quality of materials will disclose problems requiring research. Research will be better focused on the real national interests and the real technical questions if the investiga- 
tors participate actively in problem identification, research planning and planning for application of research results.

The disadvantages of placing the Nicaraguan Building Institute in the National University are as follows:

- The university laboratories would have to carry out a large volume of repetitive work which is not directly in its interest. The national laboratories must serve the interests of the state, which are focused on the economic development of the country and the safety of its citizens. The interests of the university are different; focused primarily on the preservation, transmission, and growth of knowledge. The university cannot commit itself fully to goals différent from its own. As a consequence, the professors or researchers who work in the laboratory must sacrifice a large part of their time in routine technical work and administration which interfere with their academic careers.

o The large volume of routine work mentioned above requires a large nonacademic staff. The laboratory attains a size much larger than its relative academic importance in the university and can become a severe economic and administrative burden.

- The national laboratory in its work of control of quality has a rhythm of activities corresponding to those of the building industry, which is different from that of the university. There are also increased dangers of strikes or riots interfering with laboratory functions.

- The research interests of the state and university may differ.

In the balance of advantages and disadvantages, it seems inconvenient to make the university responsible for the national laboratory. But there are great advantages in collaboration. Therefore, if at all possible, the national laboratory should be located close to the university and the university should have a definite role in the activities of the national laboratory.

\subsection{Relations with Private Laboratories}

In addition to the laboratories of the National University of Nicaragua, which presently provide quality control for building materials, there also exists in Nicaragua, two private laboratories; LAMSA and NICASOLUM. These laboratories work principally in soil mechanics, but also test building materials.

The creation of the Institute would not cause a reduction in the activities of these laboratories. On the contrary, their volume of work should increase because of the work required in the reconstruction, and particularly because of the greater requirements for control of quality of materials which should be called for in the building code.

The essential laboratory functions of the Institute consist of inspection of the private laboratories, development of codes and standards, and education activities. In testing for control of quality of building materials, the national laboratory will be occupied principally with problems of general importance, which affect a large number of consumers, while the private laboratories will be occupied with private works. Initially, the Institute may undertake control of the quality of materials at their origin, services required by the Ministry of Public Works, and official inspections of work. These testing responsibilities can be considered flexible and modified in accordance with circumstances.

\section{Organization and Objectives of the Laboratory}

A properly equipped laboratory of the Nicaraguan Building Institute is essential to the building regulatory system. For development and revision of building codes and standards, the laboratory must provide the necessary 
experimental knowledge, including data obtained from quality control testing and from special experimental programs. The laboratory must participate in the implementation of the building code, directly through control of quality of materials and indirectly through inspection of private laboratories. The laboratory also must participate in education, in the vocational education of technicians and building tradesmen, in the curricula of engineering students, in thesis research for professional degrees, and in post-graduate research for professionals.

For the organization of the laboratory, these functions may be classified as follows: tests for control of quality; special studies for evaluation of specific designs, research, or development; teaching and demonstrations of building practices; and inspection of other laboratories. These may be abbreviated, respectively, as: control, research, teaching, and calibration. Aside from the last function, which requires special methods, the other three have many methods of testing in common. However, it is necessary to consider co-existence of these three functions in the same laboratory for the selection of the number and type of testing machines and equipment.

These functions must be carried out for the various materials which include: cementing materials, bricks and tiles, metals, woods, and plastics. For convenience in use of equipment and test methods, the laboratory may be organized in the following sections:

1. Binders, which includes cements, limes and gypsums. This section will be dedicated to the control of quality and to problems of development related to these materials or procedures for their use. This section will have equipment for tests of mortars, of admixtures, and of alka1iaggregate reactions; it will provide appropriate services for other sections.

2. Concretes, aggregates and mortars. The personnel of this section must be in permanent contact with the job sites in order to identify the problems which may exist, and they must visit those job sites where they know of the existence of special problems.

3. Prefabricates for tests of bricks, blocks, tiles, asbestos cement, pipes, joists, wall panels, poles, etc. This section will be concerned with control of quality of these elements and problems of connections between them. This section, or Woods, may include the control of the quality of plastic materials, especially of safety helmets.

4. Metals for control of quality of reinforcing bars, pretensioning wires and cables, structural shapes, lightweight sections, etc. A 1 arge part of the specimens will be sampled in the Customs house. This section also would be responsible for nondestructive testing of metals including radiographic control of welding.

5. Woods. Characterization of the national woods, basic unit stresses, grading classifications, studies of adhesives, and studies of elements such as doors and wall panels.

The mechanics of soils and bituminous materials are not included in the first stage, because some capabilities exist in the private laboratories and the Highways Laboratory. However, if it is decided to integrate the Highways Laboratory with the Institute, it will be necessary to review and improve the existing equipment.

The work of controlling quality requires inspection in factories where specimens will be taken with appropriate methods. It is recommended that quality control not be limited to providing certification of specific pieces or lots of production, but be extended to the statistical interpretation of test results to judge the quality of products with values of averages, standard deviations, histograms and fractions defective. In this way the laboratory serves in an advisory role to the manufacturer and the 
builder, as well as in support of the building regulatory system.

It is beneficial to the building community and building users to publish the useful information arising from these tests, with care to avoidance of commercial conflicts. Examples of useful knowledge include the characteristics of the common aggregates, the current values obtained on the job sites for the strengths of concretes and their dispersion, and the qualities of the foundation soils in different parts of the city. Similarly, it would be desirable to make and publish special studies to characterize the national timbers, to recommend typical proportions of concrete and mortar mixes for small projects, to provide curves of correlation between strength and rebound of the Schmidt hammer, etc.

The Institute's programs for special studies will be established to meet the most important needs of the Nicaraguan building community. Strong candidates for study include the improvement of pozzolans, use of lightweight aggregates, mix proportions for mortar for maximum bond to masonry units, and studies of shear walls. The importance of courses for the training of welders is emphasized; they would become more necessary in the event of an increase in the volume of steel construction. Also, welders must be periodically requalified, and it is necessary to impose radiographic control of welding in metal construction.

The requirements for laboratory equipment can be compiled from the ASTM standards which define testing procedures and equipment for the various building materials. Many equipment suppliers can recommend lists of equipment as well as providing quotations of prices.

There are we11-defined items of equipment for which it is only necessary to select the maker, and sometimes to decide on the number of elements when more than one is required. However, in other instances, and particularly for multiple use equipment, there are more decisions to make. In this latter class are testing machines, extensometers, measuring instruments and recording apparatus. At least three testing machines are needed for tests of specimens of various materials, each one with various scales and in conjunction covering a range from zero to about 100 metric tons in tension and to about 200 metric tons in compression. They must have load-deformation recorders and implements such as various grips, loading plates, supports for flexure and bend tests, etc. A machine for testing pipes and a small machine for tensile tests of mortar briquettes also should be considered. A testing machine made up of two frames with hydraulic jacks should be installed for tests of structural elements such as tests of walls under horizontal forces.

The equipment required for measurement of deformations includes electrical resistance strain gages for use in the laboratory and in the field with a bridge, connection box, and multiple channel recording apparatus. Mechanical and optical extensometers of various types are required with calibration equipment for al1 the deformation measuring instruments.

The loading ranges of proving rings for calibration of testing machines must provide for the apparatus in the laboratory and in other laboratories of the country.

Ultrasonic and portable $x$-ray equipment is required for nondestructive testing of metals and welds.

Equipment with a guarded hot plate, should be provided for measurement of thermal insulation.

The following equipment is recommended for the concrete laboratory. There should be two mixers of distinct capacities with vertical axes, a vibrating table and immersion-type-vibrators, a core drilling apparatus, various 
Schmidt hammers with a calibration anvil, a device for location of the position of reinforcing bars within concrete elements, and a curing chamber to be used for both cements and concretes.

It is not the intent of this chapter to provide a list of equipment, but only to bring out some suggestions. The planning for the laboratory requires a detailed investigation with a thorough study of comparable existing facilities and available references. It is estimated that a minimum investment for the testing equipment will be from 150,000 to 200,000 U.S. dollars. The building is likely to require some 800 to 1,000 square meters of usable area.

\section{Educational Programs}

The rapid economic and social progress and development of Nicaragua in recent years has led to strong demands for comparable growth in the capabilities of its building community; the emergency created by the 1972 Managua earthquake increases these demands. Professional architects and engineers are strongly motivated to learn the latest practices for earthquake engineering; this is just one of many important and rapidly advancing areas of building technology. Highly skilled subprofessionais and technicians: welders, plumbers, electricians, mechanics, masons, draftsmen, inspectors, etc., are essential to modern building practices. This group is probably the most lacking in a nation which formerly had a gap between highly educated and largely illiterate classes of citizens.

Post-graduate education for the professionals is needed in Nicaragua. There are special difficulties in instituting such a program. The universities appear to be in danger of losing their best qualified faculty to professional practice for which there is great demand during the emergency. Formal basic education and technical training are needed to develop subprofessional skills. There may be difficulties in finding equipment and qualified teachers for subprofessional training programs.

The Organization of American States has sponsored a special training program for construction workers; it achieved such success that the Government of Nicaragua has requested another, but also identified some problems. The selection of students must be the responsibility of the management of the training program; little can be accomplished if the background of students is too varied. Attention must be given to implementation of new knowledge; workers returning with new skills, which are not accepted by their supervisors, have gained little.

Establishment of programs for subprofessional training should be accompanied by a certification process which will assure adequate recognition in responsibilities and in pay, for the successful completion of training.

Modern equipment and facilities are needed for programs of subprofessional training. The Instituto Tecnico de Capacitacion in Granada, had equipment and could obtain experienced teachers in Spain. The implementation of their program was prevented by the lack of a building. This capability should be investigated in detail, and a government loan considered for construction of the building, if this program can contribute effectively to the needs of the building community for subprofessional skills.

The materials testing laboratory, discussed in this report, could provide an important additional resource in equipment and staff for the support of programs of subprofessional training.

The universities of Nicaragua, in cooperation with the Nicaraguan Association of Architects and Engineers, should develop programs of post graduate education for practicing architects and engineers. The shortage of faculty may be resolved by offering visiting appointments under United Nations or 
Organization of American States auspices to faculty from abroad. In view of the opportunities for research and special studies resulting from the earthquake and reconstruction programs, such a visiting scholar program would be capable of attracting outstanding faculty.

\section{Summary}

This review and evaluation of the Nicaraguan building regulatory system has considered:

o the performance of buildings in the 1972 Managua earthquake

o the emergency building code and the draft building code

o the status of code administration activities of review of plans and inspection of construction

o current and prospective laboratory facilities for control of the quality of building materials

o needs for an institute of building standards charged with development of Nicaraguan building codes and standards

- needs for post-graduate professional education and subprofessional and technicians training programs.

The principal conclusions and recommendations are as follows:

1. Although human suffering and property losses were severe in the 1972 Managua earthquake, numerous examples of successful performance of many types of buildings in all parts of the city show that earthquake resistant construction is feasible and economical for Managua. Future disasters can be avoided by an effective building regulatory system requiring land use planning for avoidance of damages caused by faulting and unstable slopes, and earthquake resistant design and construction practices for avoidance of damages caused by ground shaking.

2. Nicaragua has made substantial efforts to implement an effective building regulatory system. There are difficulties in its operation due to the large volume of repairs and construction, the inexperience of building designers in use of the emergency code and submittal of designs for review, and the need to recruit and train a professional staff for the review process. Special attention should be given to improving practices in submittal of designs and their review to avoid a crisis which might cause stagnation of reconstruction efforts or abandonment of the building regulatory system. A practicable solution would be provision of a team of outside experts to work with Nicaraguan reviewers and designers for a short period.

3. The focus of building code administration within the Oficina Nacional de Urbanismo is consistent with international experiences in effective building regulatory systems. If conflicts of interest arise because of the location of this activity in a ministry with direct construction responsibilities, consideration should be given to establishing it as an independent agency.

4. The draft building code reflects the latest international perspectives of code philosophy and provides essentially complete coverage of all aspects of structural performance. However, its provisions have yet to be thoroughly tested in practice, design aids and commentaries are not yet available to assist in interpretation and in use of its provisions, and the Nicaraguan building community will need training to become skillful in its implementation. For these reasons, it should be considered a first step in a program of code development extending over two to three years rather than hastily adopted in its present form.

5. The Nicaraguan building community seems able to function with the emergency code until a new code is developed. However, certain specific 
deficiencies have been identified which should be corrected promptly by the proper authorities. No control is being exerted over the quality of materials; explicit test requirements should be cited in the code and their performance required by inspection. The scope of the emergency code should be enlarged by citation of existing standards to cover structural loadings in addition to earthquakes, and the performance of important aspects of the building in addition to the structure. The code, with adjustment of loadings consistent with local hazards, should be applied to all important construction in Nicaragua.

6. Inspection services are now provided by engineering students; they are performing well in the emergency. However, for the long range, a permanent body of subprofessional inspectors should be established with training and salaries appropriate for this important responsibility. Manuals and check lists are needed for systematic organization of inspection.

7. A Nicaraguan Building Institute should be established which would include a laboratory for testing building materials and an office of building standards. The Institute should be independent of the National University since its primary role is technical support of the building regulatory system rather than teaching or basic research, but its facilities should be conveniently available for liaison and support of these university programs. The Institute also should be independent of ministries with direct construction responsibilities since these may lead to a conflict with its essentially judicial role.

8. The Institute will participate actively in Central American development of building standards and would be charged with development of building codes and standards appropriate to Nicaraguan conditions. A principal initial activity would be the improvement of the emergency building code. An international organization or international assistance is particularly important in the next several years during which Nicaraguan professional resources, available to the Institute, are limited since these resources are largely committed to design, construction, and regulatory activities related to the reconstruction.

9. The Institute's laboratory for building materials should support control of the quality of building materials and the development of improved building standards. The laboratory should be capable of all tests called for in the national building codes and standards, and should be responsible for accreditation of the private laboratories which will also provide testing services in support of the building code and standards.

10. Post-graduate programs for architects and engineers of Nicaragua should be organized by the universities and the Nicaraguan Association of Engineers and Architects to disseminate advances in practices to the professions.

11. Major training programs and facilities should be developed and implemented to increase subprofessional competence in the building community. Appropriate measures for certification of skills and adjustments of salary levels should be made to encourage effective use of these educational resources. 
11. References

[1] Matthiesen, R. B., and Knudson, C. F., Strong-Motion Instrumental Measurements, Managua, Nicaragua Earthquake of December 23, 1972, Earthquake Engineering Research Institute, pp. 21-25 (May 1973).

[2] Recommended Lateral Force Requirements and Commentary, Structural Engineers Association of California, 171 Second Street, San Francisco, California 94105 (1968).

[3] Building Practices for Disaster Mitigation, National Bureau of Standards (U.S.), Building Science Series 46, Wright, R. N., Kramer, S., Culver, C. G., editors, 483 pages (February 1973).

[4] Codigo Para los Construcciones en el Area del Distrito Nacional, La Gaceta, Ano LXXVII, No. 15, Managua, Nicaragua (24 January 1973).

[5] Sanderson, R. L., Codes and Code Administration, Building Officials Conference of America, Chicago, Illinois (1969). 


\section{ITINERARY AND CONTACTS IN FIELD INVESTIGATIONS}

This is a day by day account of the principal activities and contacts made by Ing. Atilano Lamana and Dr. Richard N. Wright in 1973, to gather the information for this report:

July $9-$ R. N. Wright

Travel to Managua, Nicaragua. Met by Mr. John Karde11, General

Engineer, US/AID

July $10-$ R. N. Wright

Briefing on mission with US/AID staff: Mr. Robert Culbertson, Director; Mr. Emerson Melaven, Deputy Director; Mr. Craig Noren, Housing.

July $11-$ R. N. Wright

Inspection of housing performance in 1972 earthquake and emergency housing with Mr. Craig Noren.

A. Lamana

Travel from Santigo, Chile, to Managua, Nicaragua.

Juiy 12 -R. N. Wright and A. Lamana

Briefing with Nicaragua staff of Organization of American States:

Dr. Cesar Cisneros, Representante; Sr. Manuel Diaz, Subrepresen-

tante; Arq. Julio Ospino.

Inspection of damage and repairs to public buildings: Ing. Jorge Hayn, Director del Departmento de Construcciones y Mantenimiento de Edificios Publicos, Ministerio de Obras Publicas.

July 13 -R. N. Wright and A. Lamana

Meeting with Ing. Cristobal Rugama, Ministerio de Obras Publicas to discuss mission.

Meeting with Ing. Humberto Porta, Director Instituto Geografico to discuss siting studies and earthquake faulting.

Inspection of Laboratorio de Carreteras, Ministerio de Obras

Publicas with Ing. Jaime Icabalceta, Director.

July 14 -R. N. Wright and A. Lamana

Travel to cities of Leon and Corinto to see building conditions and construction practices.

July 15 -Travel to cities of Masaya and Granada to see building conditions and construction practices.

Ju1y $16-R$. N. Wright and A. Lamana

Inspection of materials testing laboratory, LAMSA, Ing. Carlos Schutze, Gerente Administrative.

Inspection of laboratories of the Universidad Nacional Autonoma de Nicaragua, Dr. Abdel Karim, Decano, Facultad de Ciencias and Ing. Adolfo Diaz, Director, Departamento Ingenieria.

July 17 -R. N. Wright and A. Lamana

Briefing on activities of the Oficina Tecnica de Construccion Sismica Nacional, Ing. y Dr. Armando Hernandez, Supervisor General; Ing. Luis Bolanos, Deputy. 
Inspection of materials testing laboratory, NICASOLUM, Ing. Marcelo Rios, Ingeniero Jefe.

July 18 -R. N. Wright and A. Lamana

Meeting with committee for seismic code review: Ing. y Dr.

Armando Hernandez, Ing. Luis Bolanos, and Ing. Ernesto Carcamo, Oficina Nacional de Urbanismo; Ing. Christian Icaza, Arquitectura $y$ Construccion S. A., representing the Association Nicaraguense de Ingenieros y Arquitectos.

Meeting with Arq. Eduardo Chamorro, Disenso y Construcciones, S. A., and a member of the private sector Panel for Reconstruction.

July $19-R$. N. Wright and A. Lamana

Meeting with committee for seismic code review (persons noted above) to confirm perspectives of earlier meeting.

Discussion of procedures for review of plans and inspection, Oficina Tecnica de Construccion Sismica Naciona; Ing. y Dr. Armando Hernandez, Supervisor General; Ing. Ernesto Carcamo, Jefe de Revision; Ing. Noel Zamora, Jefe de Inspection.

Discussion of procedures for building and occupancy permits. Ing. Rolando Hernandez, Jefe, Seccion de Permissos, Oficina Nacional de Urbanismo.

Discussion of mission and building regulatory system with Ing. Salvador Lopez, Director, Oficina Nacional de Urbanismo, Ministerio de Obras Publicas.

July $20-R$. N. Wright and A. Lamana

Discussion of programs for education of subprofessionals such as craftsmen and inspectors with Dr. Cesar Cisneros, OAS.

Briefing of OAS and AID personnel on progress in our mission: Dr. Cesar Cisneros, Representante, Arq. Julio ospina, and Srita Christann Sanchez of OAS, Mr. Robert Culbertson, Director, Mr. Fred Alvarez, Engineer, Mr. Craig Noren, Housing, and Mr. John Kardell, Engineer of AID.

Meeting with Nicaraguan architects, engineers and contractors to discuss perspectives of the building regulatory system: Arq. Eduardo Chamorro, Disenos y Construcciones S. A.; Arq. Julio Villa, Director, Sovipe Ingenieros S. A.; Arq. Jose Francisco Teran, Director, Arquitectos y Ingenieros S. A.; Ing. Frederico Fielder, Ministerio de Distristro Nacional; Ing. Carlos Santos; Arq. Roberto Sanson.

July $21-R$. N. Wright and A. Lamana

Travel to Mexico City, Mexico

July $22-R$. N. Wright and A. Lamana

Visits to construction sites in Mexico City and State of Mexico with Dr. Ramon Echenique-Manrique, Investigador en Ciencia $y$ Technologia de la Madera, Universidad Nacional Autonoma de Mexico (INAM).

July $23-R$. N. Wright and A. Lamana

Visit to office of the Organization of American States in Mexico to arrange contacts in Mexico with persons contributing to a new building code: Sr. Jose Carlos Ruiz, Representante, Arq. Heriberto Allende, Division de Desarrollo Urbano. Reported at U.S. Embassy, Mr. John Amott, Economics Section. 
July 24 -R. N. Wright and A. Lamana

Further arrangements with OAS, review of building code provisions, meeting with Dr. Juan Casillas, Decano, Facultad de Ingenieria, UNAM .

July $25-R$. N. Wright and A. Lamana

Inspection of laboratories at UNAM, discussion of work on building code development for Nicaragua and Mexico with personnel of the Instituto de Ingenieria: Dr. Emilio Rosenblueth; Ing. Luis Esteva, Subdirector; Dr. Daniel Resendiz, Subdirector; Dr. Roberto Meli.

July $26-R$. N. Wright and A. Lamana

Briefing Mexican office of OAS on progress: Sr. Jose Carlos Ruiz, Representante; Arq. Heriberto Allende and Lic. Jorge Videla, Programa de Desarrallo Urbano.

Development of outline for report, review of proposed code.

Juiy 27 -R. N. Wright and A. Lamana

Discussion of Nicaraguan building regulatory system with Dr. Emilio Rosenblueth, Instituto de Ingenieria, and Dr. Ezio Faccioli, UNESCO, expert in soil dynamics at UNAM.

July $28-$ A. Lamana

Travel to Guatemala City, Guatemala.

July $30-$ A. Lamana

Visit to ICAITI, Instituto Centro Americano de Investigacion y Technologia Industrial. Meeting with Ing. Gabriel Dengo, Subdirector; Ing. J. Joaquin Bayer, Chief of the Division of Analysis, Experiments and Tests. Discussion concerned the coordinative work of ICAITI in standards for Central America.

Visited the laboratories of the Center of Engineering Research of the University of San Carlos. Meeting with Ing. Emilio Beltranena, Director, and with Ing. Oscar Asturias on methods of review, inspection and control of quality of materials in Gua tema 1 a.

Travel to Managua, Nicaragua.

JuTy $31-A$. Lamana

Met with OAS officials to plan future work. Met with Ing. Francisco Robleto, Executive Director of the Nicaraguan Center for Promotion of Exports.

August $\mathrm{T}-\mathrm{A}$. Lamana

A holiday in Managua. Observed damages to buildings in the center of the city, especially the forms of failure of masonry walls.

August $2-A$. Lamana

Meeting with Dr. Abdel Karim, Dean of the Faculty of Sciences, on the building code. Visited with him, the Colonia Centroamerica for information on methods of repair. Worked in preparation of lists of equipment for laboratories.

August $3-A$. Lamana

Meeting in the Oficina Nacional de Urbanismo with Ing. Salvador Lopez, Director, Ing. y. Dr. Armando Hernandez, Supervisor General, and Ing. Edmundo Davila, Chief of Constructions and Repairs. 
Meeting with Dr. Alejandro Baca in the Camara de la Construccion to learn about amounts of production of materials.

August 4 -A. Lamana

Observing damages in subdivisions Bello Horizonte, Salvadorita and buildings in the center of the city.

August 5 - A. Lamana

Work in preparation of lists of equipment for laboratories.

August $6-A$. Lamana

Visited the Colonia Altmira d'Este accompanied by inspectors from the Oficina Nacional de Urbanismo, Messrs. Matus and Solozano. observed methods of construction of masonry.

Meeting with the Minister of Public Works, Ing. Cristobal Rugama, together with the representative of OAS, Dr. Cesar Cisneros to discuss progress in the mission.

August 7 - A. Lamana

Met with the Minister of the National District, Sr. Luis Valle olivares to discuss the mission.

Met with Oficina Nacional de Urbanismo with Ing. Edmundo Davila y Noel Zamora.

August $8-R$. N. Wright

Briefing of OAS and AID staff in Washington: Arq. Philip Huber, Director, Urban Development Program, and Arq. Celestino Sanudo, OAS: Mr. William Mann, Chief, Housing and Urban Development, Harold Robinson, Housing and Urban Development, Paul Wenger, Finance Officer, and Thomas Mehen, Nicaraguan Desk Officer for Economic Affairs, of AID Latin American Bureau.

A. Lamana

Travel to Washington, D. C.

August $9-R$. N. Wright and A. Lamana

Visit to the laboratories for testing materials of the National Bureau of Standards. Meeting with Dr. Robert Crist, Assistant Chief, Office of Federal Building Technology, to obtain information on equipment for laboratories.

August $10-A$. Lamana

Meeting with Arq. Philip Huber, Director, and Arq. Celestino Sanudo of the Programa de Desarrollo Urbano of OAS to inform them of progress in the work.

R. N. Wright and A. Lamana

Work at the National Bureau of Standards on preparation of the report.

August 21-R. N. Wright and A. Lamana

Work at the National Bureau of Standards in preparation of the report. Meetings with: Ing. J. W. Haverfield, Materials Reference Laboratories, on methods for inspection of laboratories and essential laboratory equipment, and Dr. Felix Yokel and Dr. George Fattal of the Structures Section on problems of resistance of masonry walls to shearing forces. 
Presentation of the report on August 21, 1973:

Samuel Kramer Center for Building Technology

Celestino Sanudo Organization of American States

Antonio Quesada Organization of American States

David E. Sarfaty Organization of American States

Osvaldo Bedini Organization of American States

J. A. Van Fleet Inter-American Development Bank

Oscar C. Reyes Inter-American Development Bank

Thomas R. Callaway Department of Housing and Urban Development

Miss Patsy McCoy provided cheerful and efficient assistance in arrangements for the study and in typing the draft of the report. Miss Carol Gooden did excellent work in the final typing. 
The purpose of this paper is to describe the role of standards and of the building regulatory system in improving the safety and functionality of buildings and other elements of the manmade environment. Specific attention is given to standards for mitigation of earthquake hazards, but the procedures for developing design standards reflecting the state of the art of science and technology and for implementing them through the building regulatory system are equally applicable to all natural and manmade hazards.

This paper was drafted for the U.S./Nicaraguan Reconstruction Technical Seminar held in Managua, June 20-21, 1973, cosponsored by the Domestic and International Business Administration, U.S. Department of Commerce, and the members of the Nicaraguan private sector who agreed to participate. It takes a general view of procedures for building code enforcement, legal authorities for building regulations, and procedures for the development and implementation of standards. Hopefully, this description will be adaptable to a wide variety of situations for building regulation. This description is based on a major recent review of building practices for disaster mitigation (1) I .

It must be emphasized that earthquake resistant construction is entirely practicable with good building practices. Earthquakes, hurricanes, floods, etc., are natural hazards; they are not natural disasters. They are extreme environments which we know will recur from time to time. Disaster denotes the extensive losses of life and property which can occur from the chain reaction of failures resulting from man's neglect of these natural hazards in his building practices.

\subsection{Approach}

This paper begins with the description of the building process, its principal actors, and the roles of standards and the building regulatory system in this process. Then, standards are described in some detail. There are a number of types of standards for specific uses. There are a variety of processes for the generation of standards. Design standards, and the building code provisions citing them, are becoming more directly focused on the performance desired by the user and the "limit states" (mechanisms of failure) which may lead to unsatisfactory performance. Examples of limit states and the structural properties controlling their occurrence are discussed for some common types of buildings when subjected to seismic loads.

Interfaces of the building regulatory system with the building process are noted. The organization and administration of the building regulatory system are described. Examples are given of systems which have been particularly effective, and others which have been particularly ineffective, in providing earthquake resistant construction.

Numerals in parentheses refer to entries in the list of references. 


\subsection{Building Process}

A simplified, schematic diagram of the building process is shown in figure 1, which is taken from reference 2. The early phases, the feasibility study and program analysis, decide such matters as where the building will be located, how much space will be provided and what characteristics of the space are required. The principal actors in this activity are the owner and the architect. It is important to obtain breadth of professional inputs in programming. Specialists such as the engineering geologists may guide in the site selection; the structural engineer can assist in selection of a structural scheme well adapted to site conditions and intended use.

The design phases, schematic design and design development, are concerned with the development of a solution meeting the requirements developed in programming. Principal participants in design include the architect, structural engineer, mechanical engineer, foundation engineer, etc.

The contracting phase, involving preparation of contract documents and bidding or negotiation for selecting the contractor, requires preparation of detailed working drawings and specifications by the design team or potentia contractors and the preparation and evaluation of contractors' offers. The construction phase involves the actual construction and its surveillance. As discussed below, the design team should play an important role in this phase.

The final part of the building process occupancy has, as principal actors, the persons using the building, those who maintain or remodel it, and, hopefully, if we are to learn from our past mistakes, some surveillance by the planning and design team which allows them to evaluate the success of their design concept.

\subsection{Building Regulatory System}

Major interactions of the building regulatory system with the building process also are shown in figure 1. The principal elements of the building regulatory system are: (1) the building regulations denoted as "code", and (2) the regulatory agency or agencies which enforce and interpret the codes.

The codes speak directly to certain aspects of the building and the building process:

o land use, defining the natural and manmade environments,

o design, controlling the performance of the building in the natural and human environments,

o construction, controlling how the design is implemented,

o occupancy, controlling how the building is used, maintained, remodeled, or removed.

The usual interactions of the building regulatory system and the building process are shown in figure 1. The codes themselves are referred to by the planners and designers during the programming and design stages to assure that these regulations are complied with. The building regulatory system reviews the planning and design when appropriate documents describing the designer's conception are made available to the building regulatory system. This interaction is denoted "agency" in figure 1. Following approval, after any necessary modification, the building regulatory system promotes compliance with the design during construction by field enforcement. These processes of inspection, and sometimes of evaluative review, may be continued after construction to assure appropriate occupancy.

The responsibilities of the regulatory system are summarized in figure 2. The building regulatory system is responsible for development and maintenance of the building code (here considered to include land use, zoning, 
subdivision, and other regulations), the process of examination and approval of plans which assures their compliance with the code, and field enforcement which assures that the construction and occupancy are in accord with the code and plans.

\section{STANDARDS FOR BUILDING}

\subsection{Types of Standards}

A standard is commonly defined as "that which is established by authority as a rule for measuring." Since the term is used by many with differing shades of meaning, let us define some terms for use herein:

o Specification: a stated rule for measurement

o Standard: A broadly accepted specification

o Code: a legal requirement for application of a standard

Note these terms are distinguished by the process of promulgation. A standard is textually like a specification, but it has been accepted through an appropriate process by a group which is recognized to issue standards. A code is issued by a lawmaking body.

Standards may be classified in accord with the type of rule for measurement they present. Sanderson (3) notes the following classes:

- Engineering practice, such as a method for predicting the strength of a beam

o Material, such as a broadly accepted definition of a type of cement

o Test method, such as a procedure for stating the strength of concrete

Note that standards of these categories can be referred to in a code.

Standards may be either performance or prescriptive in nature. James Wright (4) has compared these approaches to building standards. A performance standard expresses the desired attributes of the product or process in question; any scheme which results in achievement of these attributes meets the standard. This approach promotes economy and innovation since it focuses on the users' requirements. The prescriptive standard is a specific definition of an acceptable process or product. The desired attributes often are unstated; the process or product may meet the standard but may not meet the users' needs. Prescriptive standards have the advantage that they are quite objective. It is relatively straightforward to evaluate and determine whether or not the standard is complied with. However, prescriptive standards do not assure satisfaction of the users' needs, let alone in an optimal fashion. Performance standards do have the disadvantage that it is conceptually more difficult to evaluate whether they are complied with. As indicated in figure 3, a laboratory-type activity may be required to evaluate the compliance. In fact, we see current efforts to develop prescriptive standards for the process of evaluation of performance standards (5).

Performance standards should not be seen as the antithesis of prescriptive standards. Both have their place. Performance standards are essential for description of the desired attributes of the building. It is most meaningful to the user to say: "The building must have less than 1 percent probability of unserviceabijity from earthquake per year. " Prescriptive standards are useful statements to the designer or to the builder of exactly what is wanted. It is quite clear that this stress is to be computed as P/A or that ties on reinforcing bars will be separated by no more than $1 / 4$ of the depth of the column. Ideally, prescriptive standards for particular types of buildings (such as reinforced concrete frames) will be calibrated to provide the attributes desired for particular classes of occupancy, such as hospitals. 


\subsection{Land Use Planning}

Land use plans provide standards which substantially affect the safety of buildings from earthquakes or other hazards. Wiggins, et al., (6) review the state of the art of land use planning for disaster mitigation and provide a guide to literature in the area. The major elements of land use planning are:

- The general plan, which is a prescriptive standard for a geographical area describing how land use is to develop.

o Zoning regulations, which describe the conditions for land use for various purposes. One set of zoning regulation may be applied to a variety of general plans.

- Subdivision regulations prescribe in detail how land is to be used when subdivided for a specific purpose.

Planning for disaster mitigation may take two approaches. One is exclusionary, totally preventing certain land uses in certain areas. This approach is appropriate when these land uses would be clearly undesirable. Another approach is microzoning in which the land use plan defines the intensity of natural hazards for specific areas. The microzoning approach allows considerably greater flexibility in land use. Land use is not arbitrarily restricted but results from an economic balance between the benefits and costs of rational land use.

Microzonation for earthquakes will account for intensity of ground shaking, hazards of permanent ground movements such as landslides and fault displacements, and recurrence intervals for earthquake induced flooding and wave action. The forces of ground shaking usually can be accounted for in all types of buildings and occupancies. The other effects are considerably more critical; if their hazards are high, exclusionary zoning is usually required. Microzoning for wind effects is similar. Wind velocity, as affected by topography and surface roughness, can be accounted for rationally in building design. Wind induced storm surges sometimes can be accounted for by design; otherwise, these areas may be avoided for construction. Building exclusion from flood plains is a common form of land use regulation. However, mitigation of flood damage also can be provided in design. Volcanic effects require attention in regional land use planning, and usually require exclusionary planning.

\subsection{Consensus and Industry Standards}

Recalling that a standard is distinguished from a specification by its acceptance by some constituted body, the distinction between consensus and industry standards is in the group accepting them. Industry standards will be accepted by a specific industry or trade association. An example is the American Institute of Steel Construction specification for the design, fabrication and erection of structural steel for buildings. A consensus standard will be accepted by a group representing the general public interest including industry, the professions using the standard, and the consumers affected by the process or product standardized. The major American consensus standard organizations, neither one of which is affiliated with any governmental body, are the American Society for Testing and Materials and the American National Standards Institute. The American Society for Testing and Materials promulgates standards dealing with both materials and test methods. The American National Standards Institute promulgates a wide variety of standards including test methods, engineering practices such as design loads for buildings, and very complex products such as mobile homes.

The process for promulgation of a consensus performance standard is shown in figure 4; a similar process is used for prescriptive standards. Usually the standard is drafted by a vitally concerned sponsoring group. 0ften this group represents the industry or profession using the standard. The 
standard is reviewed by a committee representing all affected parties. Two elements are important in the review:

o Technical correctness, does it reflect the state of the art of technology?

- Performance levels, is the performance called for adequate and yet not requiring wasteful overinvestment in unneeded performance?

Generally the process of review includes a publicly recorded vote. Substantial negative votes will preclude promulgation of the standard; all negative votes must be specifically considered and resolved.

\subsection{Structural Design Standards}

From a performance viewpoint, structural design standards pertain to one or more of the following objectives in disaster mitigation:

o avoid human suffering

o avoid property loss

o preserve essential functions

To achieve these objectives, the designer must give explicit attention to the limit states (7): ultimate limit states involve some permanent degradation of the system; functional limit states involve a permanent or transient loss of functionality. These considerations of performance and limit states pertain to structural design standards for any type of loading. For seismic loads, particular attention must be given to 1 imit states generated by the dynamic response of the structure and to mechanisms of energy absorption. Energy absorption is important as a means for reducing dynamic response and thereby maintaining functionality or avoiding property loss, and as a means for preserving life safety under very great (but infrequent) loadings for which property losses and losses of functionality are tolerated.

Design standards provide guidance in selection of methods of analysis for prediction of structural response. Sharpe, et al., (8) describe the capabilities of available analytical methods. The dynamic nature of the loading, the need to account explicitly or implicitly for inelastic behavior, and the soil-foundation-structure interaction complicate the analytical process and make it a major part of the design effort. The domains of validity for equivalent static load analysis, response spectrum analysis, and time history analysis are described for guidance to specification of these approaches in design standards.

Structural design criteria must provide for the desired level of performance by consistent selection of design loadings, response analyses, and proportioning procedures. The state of the art for definition of loading severity is discussed on a seismological basis by Algermissen (9) and for a specific building site by Donovan (10). Newmark and Hall (11) describe the general nature of the principles upon which earthquake resistant design is based, and consider the development of design procedures for structures, facilities, and components with emphasis upon the use of the design spectrum with account for inelastic deformation. Pinkham (12) reviews the evolution of an experience with current seismic design criteria, and points out where experiences in recent earthquakes illustrate needs for improvements in criteria.

In the establishment of structural design criteria the decision is made on how the building should behave for various levels of earthquake excitation. Then, both analytical procedures and proportioning criteria can be focused on assuring the desired behavior under the design conditions. Bresler (13) describes how structural elements respond to the cyclic, inelastic deformations induced by earthquakes. Available laboratory and field experience has defined standards conducive to avoidance of collapse in earthquakes. 
Further standards development and research will provide better guides to maintenance of important functions, reduction of property damage, and more economical designs.

It is more challenging to establish effective standards for the safety of existing buildings. Buildings constructed under earlier standards may not provide the performance levels now required by society. However, since either their strengthening or removal is very expensive, special attention to their safety is appropriate. Mcclure (14) describes available knowledge and current standards for survey and evaluation of existing buildings.

\subsection{Standards for Nonstructural Systems}

Much of the hazard to 1 ife, much of the property loss, and much loss of function results from damages to building furnishings and equipment in earthquakes or other natural hazards. Ayres and Sun (15) describe experiences with building furnishings and equipment in recent earthquakes and recommend standards and detajls for mitigation of these losses.

The safety of furnishings and equipment provides a special problem in standards writing since the design and installation very rarely involves the structural engineers who tend to be most conscious of earthquake effects. It must be recognized that buildings will move in earthquakes. Furnishings and equipment must be designed to accept the anticipated motions without damage and to hold together under the shaking the building will undergo.

The failures of utilities and industrial equipment cause substantial losses in earthquakes and other natural disasters. Enforcement of standards for these facilities has not traditionally come under the authority of the building regulatory system even though the consequences of failures of these systems are equally relevant to public safety. Descriptions of these failures $(16,17)$ suggest that design standards comparable to those applied for buildings or for the furnishings and equipment of buildings, should be developed and enforced.

\subsection{Building Codes}

The building code is essentially the collection of standards whose application is required by law. The history of the development of the building regulatory system in the United States, Baseler (18), has led to a large number of building codes and code authorities. The principal collections of building standards are the so-called model codes (the Basic Building Code of the Building Officials and Code Administrators International Inc., the Uniform Building Code of the International Conference of Building Officials, the Southern Standard Building Code of the Southern Building Code Congress, and the National Building Code of the American Insurance Association). For the first three, the standards are generated by a consensus-like process in which affected professional and industrial groups can recommend standards and speak for or against their adoption. However, the voting for adoption is limited to the building officials who are the members of these organizations.

The individual States of the United States of America possess the primary constitutional authority for building regulations. The States have joined together in the National Conference of States on Building Codes and Standards (NCSBCS) for coordinated efforts in development of standards and code administration procedures. Statewide building regulations have been established by 23 states. In many instances, this amounts to uniform, Statewide implementation of one of the model codes.

Federal agencies establish standards for the buildings they construct or use themselves, or the buildings which are Federally assisted in construc- 
tion, for example, by a Federally guaranteed mortgage. Federal standards are published for review and comments by all affected organizations, interests, or individuals before the standards are implemented. Conflicts may be resolved by informal discussions or legal processes.

The development of a building code for a local government or a State involves complex interactions of many parties as noted in figure 5 .

\subsection{Housing Codes}

Housing codes control the conditions of occupancy of buildings. To date, these codes have been concerned with public health under essentially normal conditions of use. When consideration is given to the relationships between normal conditions of use and the hazards which may arise in the event of an earthquake, it is evident that attention should be given to seismic risks in the development of housing codes.

\section{ADMINISTRATION OF CODES AND STANDARDS}

\subsection{Functions of the Building Regulatory system}

The principal functions of the building regulatory system are related to the participants in the building process in figure 2. The totality of activities of the building regulatory system is somewhat broader:

- generation and maintenance of standards and codes

o administration of codes

review of plans

inspection of construction

testing or approval of testing of materials and components

inspection of conditions during occupancy

emergency measures for public safety

o licensing of professionals involved in the building process

o education of the staff of the building regulatory system

The organization and administration of the building regulatory system must provide for the effective conduct of these functions. There are a variety of organizations possible for these functions. In the following sections some United States experiences are noted.

\subsection{Organization of the Building Regulatory System}

Technical standards for inclusion in building codes follow generally the process of development sketched in figure 3 . The group developing the standards language may be an industrial, professional, or governmental organization with particular concern for the specific technical area. All of these groups have strong commitment to the building process. Generally, one or more will react promptly when a need for improved standards becomes evident in the building community. The appropriate role of the building regulatory system is to assure that there is standards generating activity where needed, and to provide, solicit, or endorse appropriate financial support for the generation of standards.

Building code administration is part of the police power of the government. Sanderson (3) notes that it effectively implements the required legal authority only when it reports directly to the chief executive, focuses all enforcement for land use, building, and housing codes in one agency, and has this enforcement activity as the sole function of the agency.

These activities require a well qualified staff sufficient in number to: maintain the quality of the building code, evaluate all planned construction, and oversee activities during construction. Substantial investment in the building regulatory system is essential to the general public bene- 
fit. The sources of revenue for the building regulatory system are discussed by 0'Bannon (19). It is appropriate to charge some of the costs to the direct users through charges for building permits and inspections. However, a substantial part of this activity, as well as that for maintaining the building regulations, provides benefits to the general public and should be supported from the general revenue. It is particularly important not to assess the builder for the costs of inspection and testing. Under these circumstances, the inspector and testing laboratory come to feel they work for the builder and identify with his concerns rather than those of the occupant and general public.

\subsection{Experiences for Seismic Regions}

As described by Pinkham (12) seismic design criteria and provisions for their implementation have evolved from actual experiences with earthquakes. The west coast of the United States has been the location of its most frequent exposure to damaging earthquakes; United States design criteria very largely arise from California experience. However, the introduction of nuclear reactors, and public concern for the secondary hazards which would arise from a earthquake-damaged reactor, have encouraged high-level scientific and professional concerns with earthquake hazards and earthquake design criteria for all regions of the United States, Newmark and Hall (11). Present activities in the Federal Cooperative Program on Building Practices for Disaster Mitigation (1) are focused on development of a new generation of seismic design standards from the extensive research and experiences of the last decade.

The Field Act of California (16) has been shown by actual earthquake experience to provide an effective approach to mitigation of earthquake hazards. The requirements of the Field Act are not generically different from those of the building regulatory system of figure 2; rather it requires by 1 aw that these activities be carried out effectively.

- Plans and specifications must be prepared by a 1 icensed architect or structural engineer.

- The plans and specifications are submitted to a specific state department for review and approval prior to contracting for construction.

- A full-time resident inspector must assure compliance with the plans and specifications. Moreover, the construction is to be supervised by an architect or structural engineer.

- Verified reports shall be submitted by the architect, engineer, contractor and inspector certifying that all work complies with the approval document.

- The state agency makes field inspections during the progress of construction.

o Any violation of the Act or false statement is a felony.

In contrast to this successful experience, every earthquake shows failure of buildings as a result of practices which are known to be inadequate for earthquake resistant construction. These include:

o critical facilities which failed at the time they are most needed by their community as a result of failure to require higher levels of performance for such facilities.

- unbraced frame structures which have sufficient flexibility and ductility to avoid structural collapse, but whose motions are so large as to induce extensive nonstructural damage with concurrent hazard to 1 ife, loss of property, and loss of functionality.

- shear wall systems which are stiff enough to reduce nonstructural damage, but show enough damage in earthquakes of limited duration to call into question their safety for great earthquakes. 
- collapses which arise from inadequate lateral force resistance and ductility.

- major structural damage from inadequate diaphragm systems to provide for horizontal transfer of 1 ateral forces.

- inadequate detailing of structural members to provide for toughness and energy absorption.

- lack of attention to providing definite clearances between elements which will move relative to one another or strong connections between elements which should move together.

o complex framing schemes which lead to concentration of deformations and local failures.

- hazards to life or property from failures of nonstructural elements.

o nonstructural elements which have acted structurally to reduce the resistance or energy absorption of the structure.

o inadequate anchorage of equipment.

o additions and modifications of buildings which lacked the attention given earthquake resistance in the original design.

There is no perfect safety. Reduced, but never zero, risks of loss from earthquakes or other hazards is achieved only for increased investment. The Structural Engineers Association of California (20) estimates the following increases in building costs (not including land, site work, or tenants improvements) to increase lateral force resistance from the nominal levels supplied where strong winds or earthquakes are not considered to the level needed in the highest seismic zone.

One and two story wood frame

One to two story brick or concrete block

Four story and up brick or concrete block Reinforced concrete

Steel frame
: 2 percent

: 8 percent

10 percent

: 5 percent

: 3 percent

These represent average values, costs can be lower when the architect's basic scheme is well adapted to lateral force resistance and much higher when it is not. The policy on appropriate levels of earthquake performance cannot be established considering first cost alone. Kunreuther (21) describes the micro and macro economic considerations involved in the costs/ benefit studies required to establish optimal levels of performance. It is illuminating to put first costs in a total lifecycle perspective. Hattis and Ware (22) point out that for a typical office building that 2 percent of the total 1 ifecycle cost is involved in the initial construction, 6 percent in the operation and maintenance, and 92 percent in the costs of activities carried out in the building. An additional 10 percent construction cost is of the order of 0.002 of the total lifecycle cost; this small investment has great leverage in mitigating losses.

\subsection{Emergency Activities}

The building regulatory system also has a primary responsibility for the public safety during an emergency such as the occurrence of an earthquake. McClure (14) describes activities which must be conducted during an earthquake emergency. The building regulatory system may have primary responsibilities in:

o rescue of persons trapped in damaged buildings

o assessment of the safety of buildings for emergency occupancy

o assessment of building damages to guide emergency allocations of governmental funding

o criteria for repairs of damaged buildings following the earthquake emergency

o updating codes and code enforcement practices in light of the lessons learned. 
It is a major responsibility of the building regulatory system to be ready to carry out its emergency functions, to learn from the emergency, and to come forth from it with an improved building regulatory system. Mcclure provides counsel on all these factors.

\section{SUMMARY AND RECOMMENDATIONS}

\subsection{The Professional Perspective}

Building standards and the building regulatory system cannot be considered to make automatic the attainment of excellent buildings. This objective can only be achieved through the participation of skilled and responsible individuals in all facets of the building process. Standards and the regulatory system do provide guidance to these individuals and protect them from the unfair competition of the less scrupulous.

\subsection{Requirements for Producing Earthquake Resistant Construction}

Earthquake resistant construction is achieved only if the activities shown in figure 1 are carried out effectively. This requires:

o proper siting and conception of the building with the aid of land use planning standards in the programming phase

o proper design with the aid of standards for the loads, response analysis and proportioning for the structure and nonstructural elements

o careful review by the building regulatory agency to assure that the land use planning and design standards were correctly employed

- careful implementation of the plans in construction with inspection by skilled representative of the building regulatory agency and the designers

o occupancy of the building under the guidance of the housing code to maintain its initial safety

\subsection{Needs for Standards for Earthquake Resistant Construction}

Experiences in recent earthquakes indicate that where current design standards are effectively applied, earthquake hazards are substantially mitigated. The most important immediate need is for the effective implementation or recognized good practices.

The seventy-one major recommendations in reference 1 speak to many needs for improved standards for earthquake resistant construction. Only a few major points can be noted here. The risk inherent in the design standards should be stated explicitly so that all parties in the building process know where they stand and so that reduced risks can be achieved where desired. The last ten to fifteen years have seen much research in earth and engineering sciences and much experience with earthquakes. Much of this new knowledge is not yet available in design standards and methodologies to the design professions. A major program of updating seismic design codes is underway under the sponsorship of the Cooperative Program on Building Practices for Disaster Mitigation.

\subsection{Needs for Improvements in the Regulatory System}

The organization of the building regulatory system is discussed in Section 3.2. Unfortunately, the ideal organization of the building regulatory system is rarely achieved. It calls for:

- focus of all code enforcement activities in one agency

o that the chief of this agency have direct responsibility to the chief executive of the level of government responsible for building regulations 
- that code enforcement be the sole function of this agency

Experience with California schools constructed under the Field Act shows that this organization of the building regulatory system is effective. It should be uniformly adopted. 


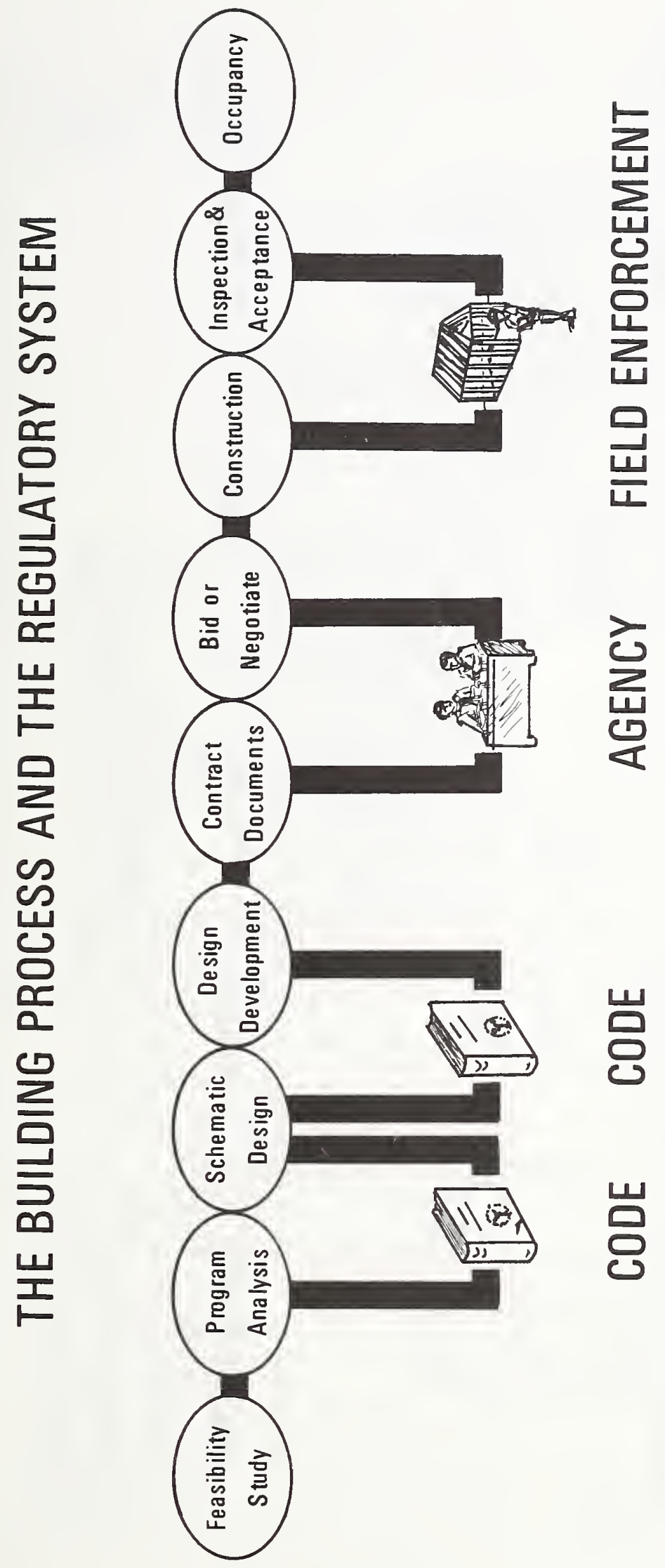




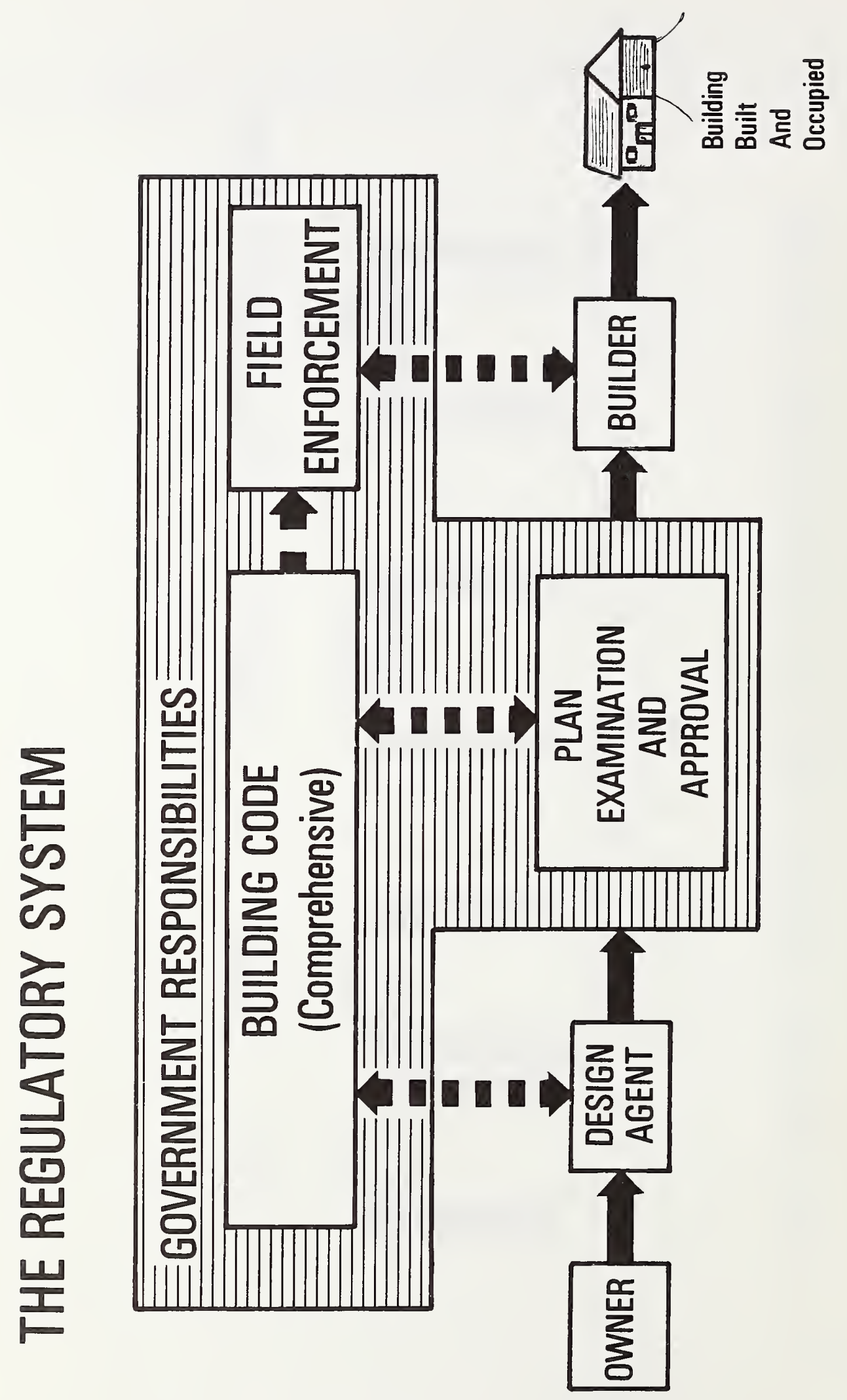


焉

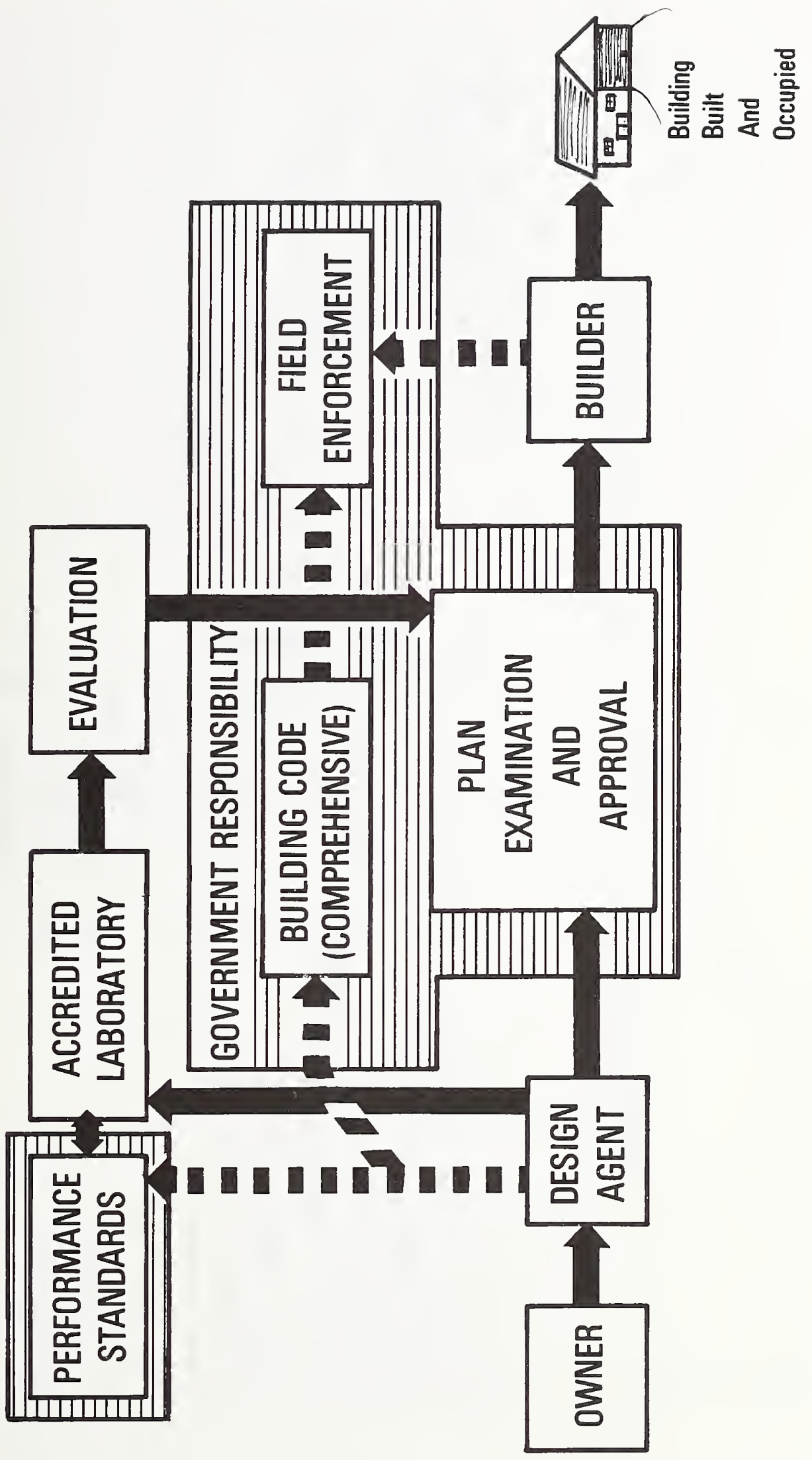




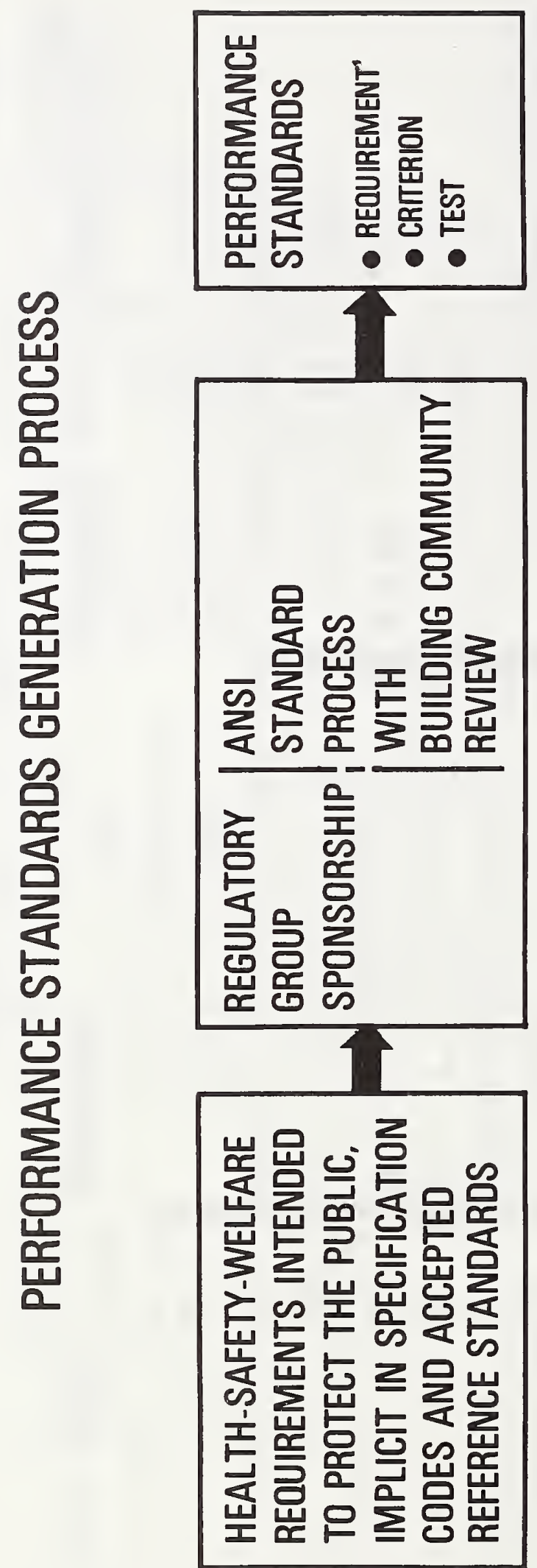




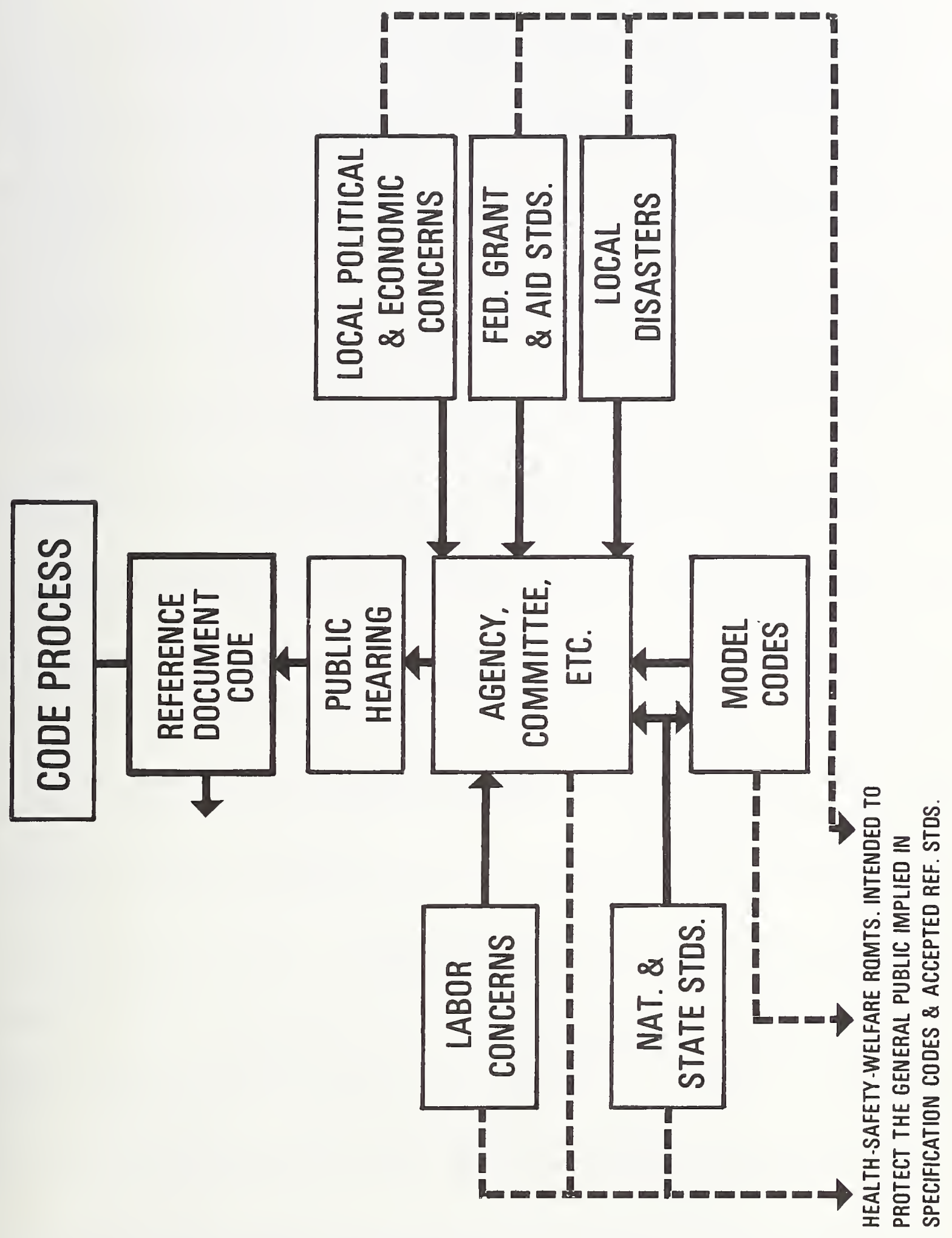


[1] Building Practices for Disaster Mitigation, Wright, R., Kramer, S., and Culver, C., editors, Nat. Bur. Stand. (U.S.), Bldg. Sci. Ser. 46, 474 pages (Feb. 1973). Available from Superintendent of Documents, U.S. Government Printing Office, Washington, D. C. 20402 , (SD Catalog No. C13.29/2:46, \$5.30)

[2] Rowland, G. A., and Gallagher, N. E., Performance Standards--Their Compatibility with the Building Regulatory System, Nat. Bur. Stand. (U.S.), 8 pages (1972).

[3] Sanderson, R. L., Codes and Code Administration, Building Officials Conference of America, Chicago, Illinois (1969).

[4] Wright, J. R., Performance Criteria in Building, Scientific American, 224, No. 3, pp. 17-25 (March 1971).

[5] Dikkers, R. D., Coordinated Evaluation System Project (CES), Model Documentation for Building Regulation, Nat. Bur. Stand. (U.S.), Tech. Note 775 (May 1973).

[6] Wiggins, J., et al., Land Use Planning and Natural Disaster Mitigation, Building Practices for Disaster Mitigation (Ref. 1), pp. 139-178.

[7] Wright, R. N., and Ang, A. H. - S., A Consistent Basis for Functional and UItimate Criteria, Performance Concept in Building, Nat. Bur. Stand. (U.S.), Spec. Publ. 361, 1, pp. 181-190 (Feb. 1972).

[8] Sharpe, R., Kost, G., and Lord, J., Behavior of Structural Systems under Dynamic Loads, Building Practices for Disaster Mitigation (Ref. 1), pp. $352-394$.

[9] Algermissen, S., The Problem of Seismic Zoning, Building Practices for Disaster Mitigation (Ref. 1), pp. 112-125.

[10] Donovan, N., Earthquake Hazards for Buildings, Building Practices for Disaster Mitigation (Ref. I), pp. 82-111.

[11] Newmark, N., and Ha11, W., Procedures and Criteria for Earthquake Resistant Design (Part II), Building Practices for Disaster Mitigation (Ref. 1), pp. 209-236.

[12] Pinkham, C., Procedures and Criteria for Earthquake Resistant Design (Part 1), Building Practices for Disaster Mitigation (Ref. 1), pp. 188208.

[13] Bresler, B., Behavior of Structural Elements, Building Practices for Disaster Mitigation (Ref. 1), pp. 286-351.

[14] McClure, F., Survey and Evaluation of Existing Building, Building Practices for Disaster Mitigation (Ref. 1), pp. 395-426.

[15] Ayers, J., and Sun, T., Criteria for Building Services and Furnishings, Building Practices for Disaster Mitigation (Ref. 1), pp. 253-285.

[16] Lew, H. S., Leyendecker, E. V., and Dikkers, R. D., Engineering Aspects of the $197 i$ San Fernando Earthquake, Nat. Bur. Stand. (U.S.), BIdg. Sci. Ser. 40, (December 1971).

[17] Schiff, A. J., and Yao, J. T. P., Response of Power Systems to the San Fernando Valley Earthquake of 9 February 1971 , Center for Large Scale Systems, Purdue University, (1972). 
[18] Baseler, P., Approaches to Implementation, Building Practices for Disaster Mitigation (Ref. 1), pp. 63-81.

[19] O'Bannon, R. E., Building Department Administration, International Conference of Building Officials, Whittier, (1973).

[20] Report of the Ad Hoc Committee on Costs of Design for Earthquakes, Structural Engineers Association of California, (Sept. 1970).

[21] Kunreuther, H., Values and Costs, Building Practices for Disaster Mitigation (Ref. 1), pp. 41-62.

[22] Hattis, D. B., and Ware, T. E., The PBS Performance Specification for Office Buildings, Nat. Bur. Stand. (U.S.), NBS Report 10527, p. B8. 
This reports a survey of the performance of modern housing developments in Managua during the 1972 earthquake. Most of the developments are low or moderate cost financed through the Banco de la Vivienda de Nicaragua, however, performance is also reported for a traditional area and a few upper income housing developments. The purpose of this report is to show, by Nicaraguan experience, that it is feasible and economical in developing or developed countries to construct buildings which will resist severe earthquake shaking. All of these housing developments were competitive in the Nicaraguan housing industry. Some performed very wel1; a more detailed study of the plans and material properties for these units will be required to quantify the characteristics which assured good performance. Some performed badly, in many instances the reasons for this bad performance were clearly indicated in visual inspection of the damages. The performance, good and bad, is described and illustrated in the inspection summaries which follow.

The writer collected some information for this report on December 30, 1973, and January 3, 1973, in company with Mr. Samuel Kramer, Chief, Office of Federal Building Technology, Center for Building Technology, National Bureau of Standards, and Ing. Raul Amador, Departamento de Construcciones y Mantenimiento de Edificos Publicos, Ministerio de Obras Publicas, Nicaragua. These earlier investigations [1] 1/ focused principally on larger public buildings. Most of the material presented here was obtained in a survey conducted on July 11, 1973, in company with Mr. Craig Noren, Foundation for Cooperative Housing, with USAID mission, Managua, Nicaragua. Mr. Noren provided the information on the characteristics of the housing developments which is 1 isted in Table 1.

The damages described herein were caused principally by very intense ground shaking throughout the whole area of the map in figure 1. A peak horizontal acceleration of $0.39 \mathrm{~g}$ was recorded [2] at the ESSO refinery just west of the Laguna Asososca at the left of figure 1. This is among the highest intensities of ground motion ever recorded for an earthquake [3]. Since the surface breakage due to the earthquake faulting [4] appeared along the lines noted near the center of figure 1, it is likely that the intensity of ground motion for all the housing developments approached or exceeded the values measured at the ESSO refinery. The seismic intensity contours reported by Hansen and Chavez [5], support this inference.

The housing units are relatively stiff, high natural frequency buildings which would be quite susceptible to damage from the relatively intense but relatively short duration earthquake which occurred in Managua. Therefore, housing units which performed well in the Managua earthquake would be likely to perform well if subjected to severe earthquake shaking in other parts of the world.

The primary conclusion to be drawn is that much of the performance was very good. In spite of the severe shaking, structural damage was in many instances negligible or light and the units remained habitable. Severe damages and collapses were observed, but these damages can be attributed generally to poor details of construction or deficiencies in the materials. It would

Numbers in brackets refer to entries in 1 ist of references. 
not have been expensive to avoid these defects. Little additional material or time is required to execute connection details well. Proper control of material quality does not add substantially to construction costs.

Good building practices in Managua resulted in housing units which withstood the severe earthquake successfully. Those which failed to perform well could have if inspection of plans and construction, and testing of materials had assured that the dimensions, details, and qualities of materials were appropriate for a zone of high seismic risk. Table 1 and the inspection summaries which follow illustrate that the poorly performing units were not systematically more economical than those which performed well. There is clear evidence that earthquake resistant construction is feasible and economical for Nicaragua or any other nation with comparable resources available to the building community. 


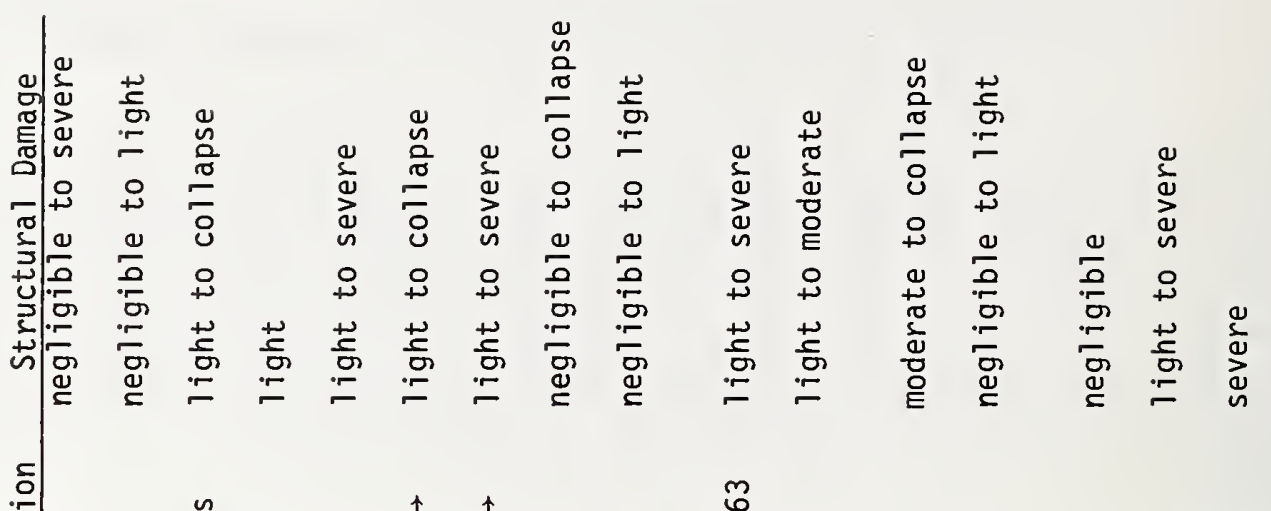

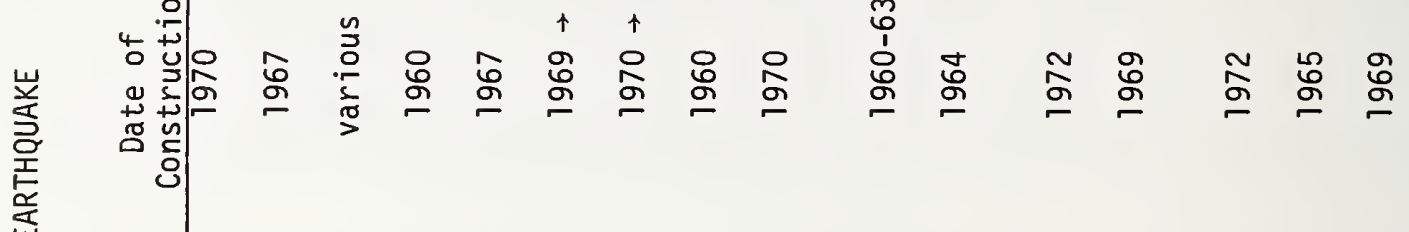

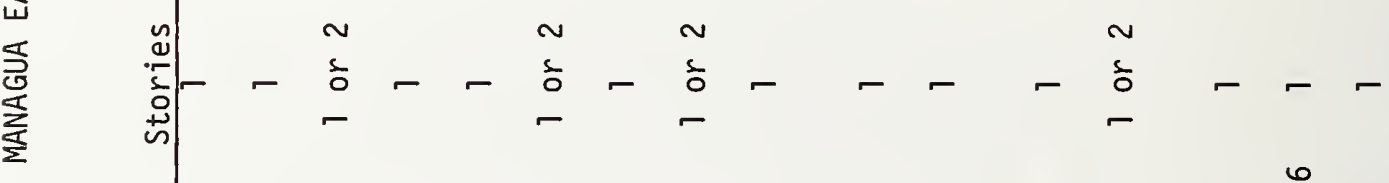

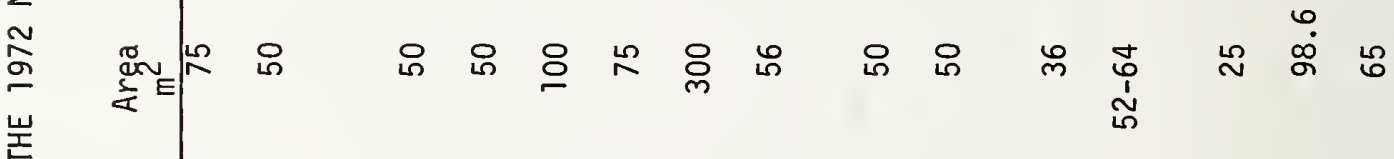
宸

尊

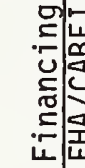

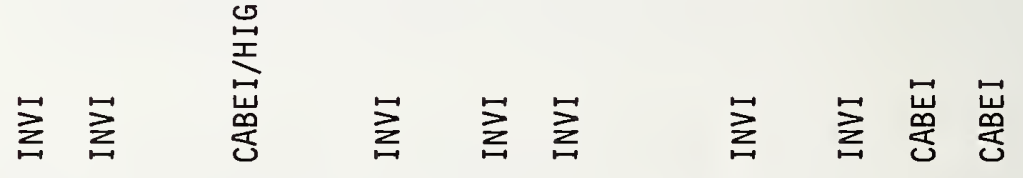

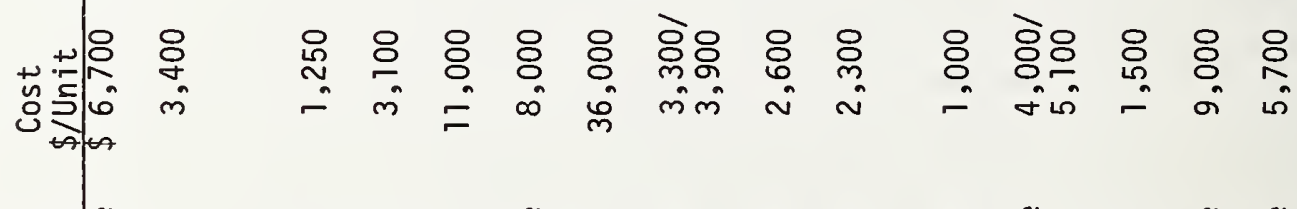

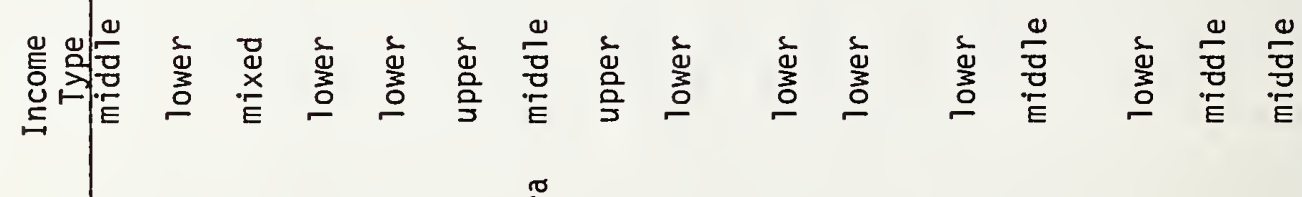

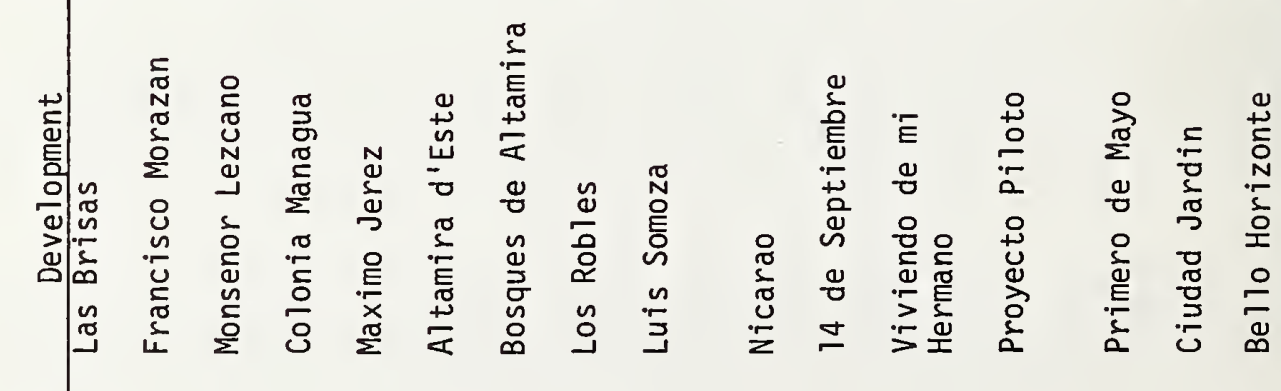
$-\stackrel{\unlhd}{5}$

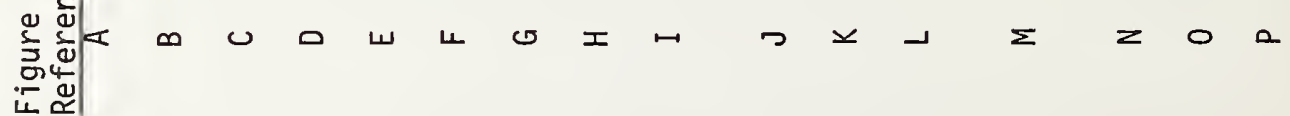




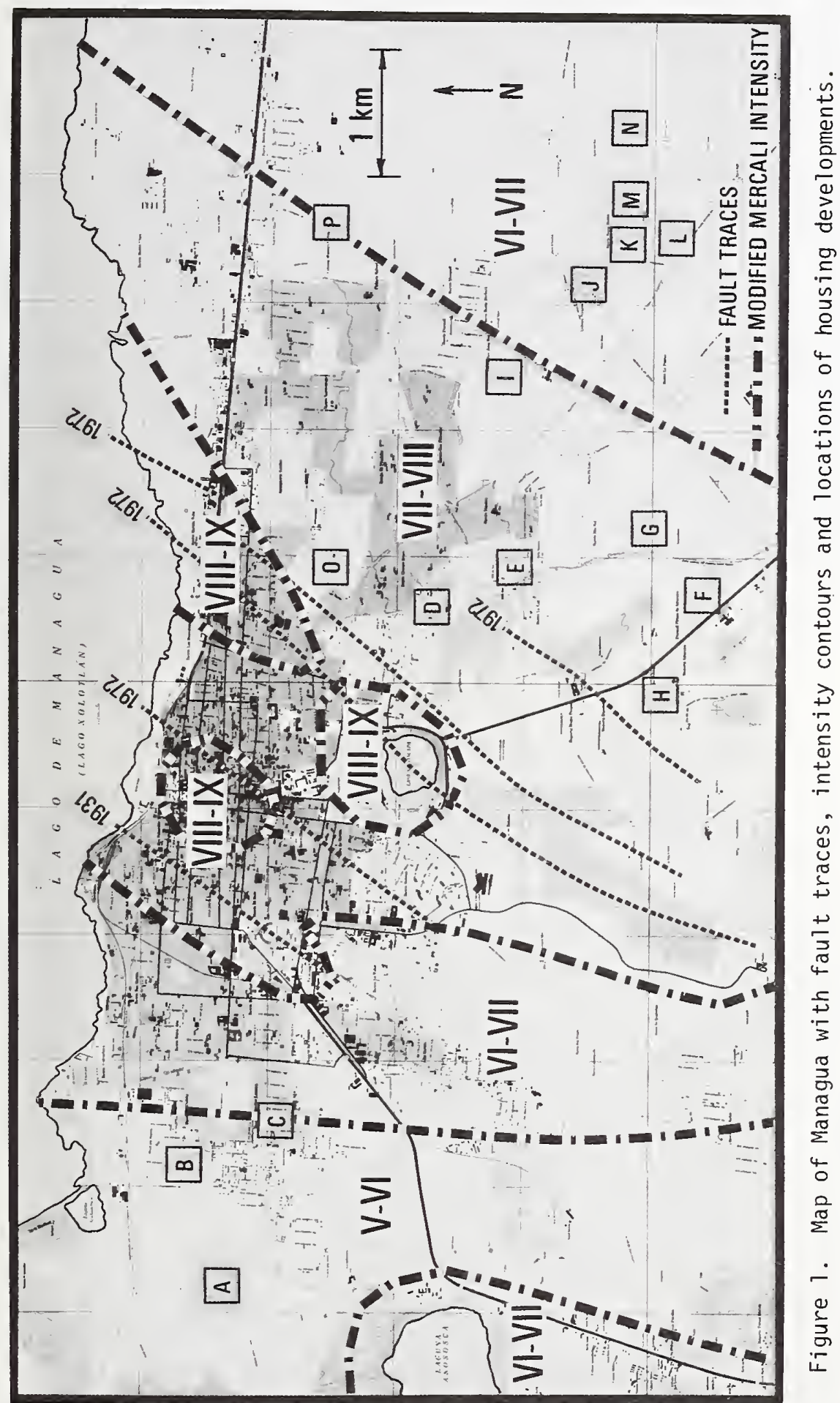


Type of Housing : middle income

Size : one story

Date of Construction: 1970

Financing: FHA/CABEI

Location : A on figure 1

Most of the units use light weight corrugated metal or asbestos roofs on timber framing. Walls appear to be masonry, concrete blocks or tile, reinforced with columns and bond beams. Damage to these units was very limited, occasional light cracking at most, not enough to reveal details of construction, figure 2; store construction in the colonia uses reinforced concrete block, figure 3 .

Near the south of the development, we found a row of houses which included a type using poured, probably precast, concrete panels and concrete panel roofs alternately, figure 4, with the type described above. The concrete panel types had all failed and had been abandoned while those of the reinforced masonry type were in good condition and in use. The failures were typically separation of panels at joints, figures 5 and 6 ; the joint details were minimal ties, perhaps just what was needed for construction loads.

Some interior panels, notably around showers, figure 7 , had fallen. This is evidence of strong shaking at Las Brisas and demonstrates the importance of careful connections in panel systems.

Housing Performance

COLONIA FRANCISCO MORAZAN

Inspection Date: 11 July 1973

Inspected by : Craig Noren

R. N. Wright

Type of Housing : lower income

Size : one story

Date of Construction: 1967

Financing : INVI (Instituto Nicaraguense de la Vivienda)

Location : B on figure 1

These units had light corrugated roof systems; some with cast-in-place concrete walls with \#2 undeformed reinforcement and some with reinforced concrete block walls. Figures 8,9 , and 10 show a unit with some cracking, most units had no such visible damage.

Housing Performance

BARRIO MONSENOR LEZCANO

Inspection Date: 11 July 1973

Inspected by : Craig Noren

R. N. Wright

Type of Housing : mixed

Size : varied, one and two stories

Date of Construction: various, probably after 1931

Financing

Location

C on figure 1

Taquezal performance, figure 11 , ranged from shaken-off plaster and roof tile to complete collapse. Wooden slab buildings showed no damage. Masonry and concrete frame construction ranged in performance from light cracking to collapse, figure 12 and 13. The closeup of figure 14, shows poor performance of unreinforced masonry. 


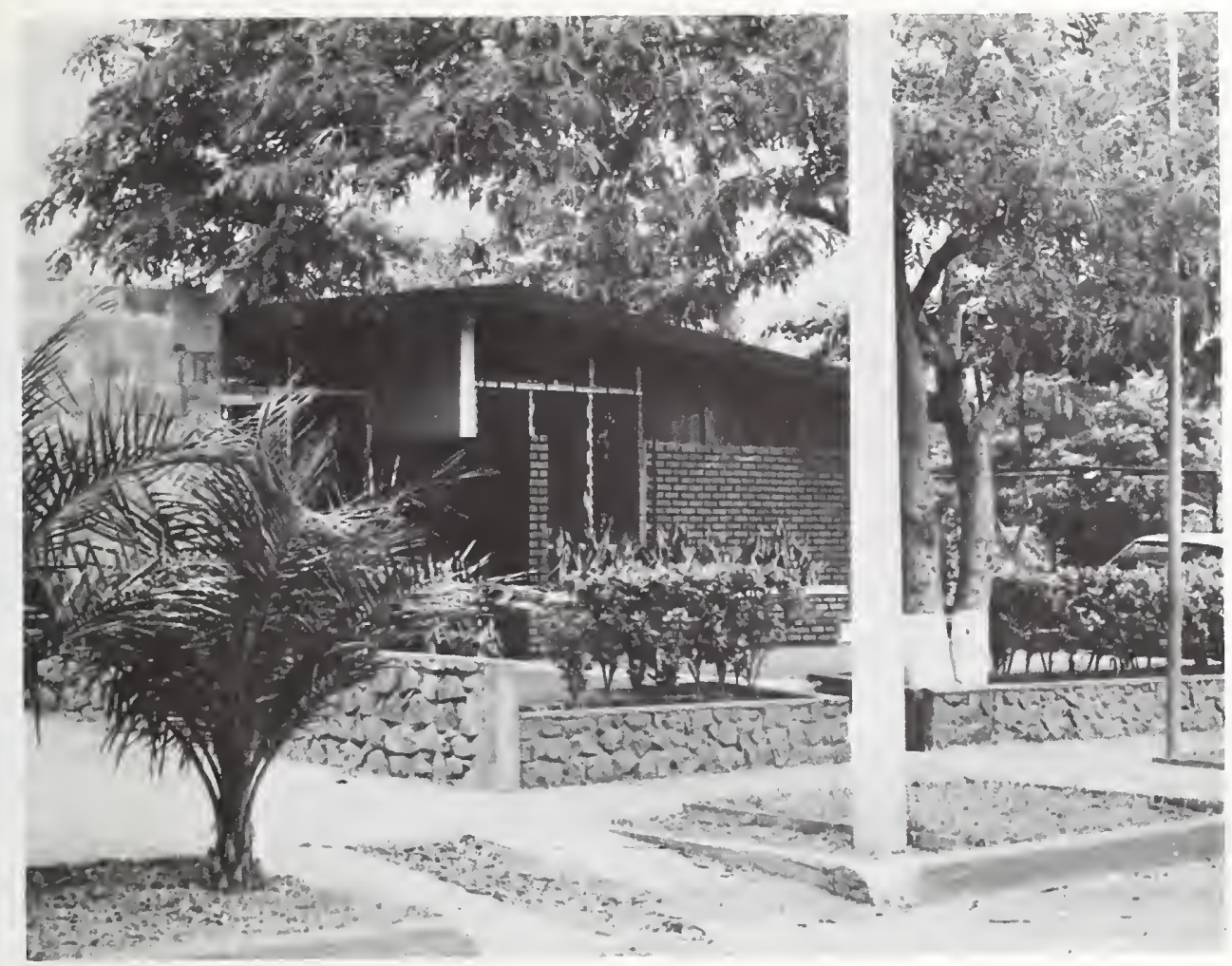

Figure 2: Las Brisas, no apparent damage to typical house.

Figure 3: Las Brisas, reinforced block masonry construction.

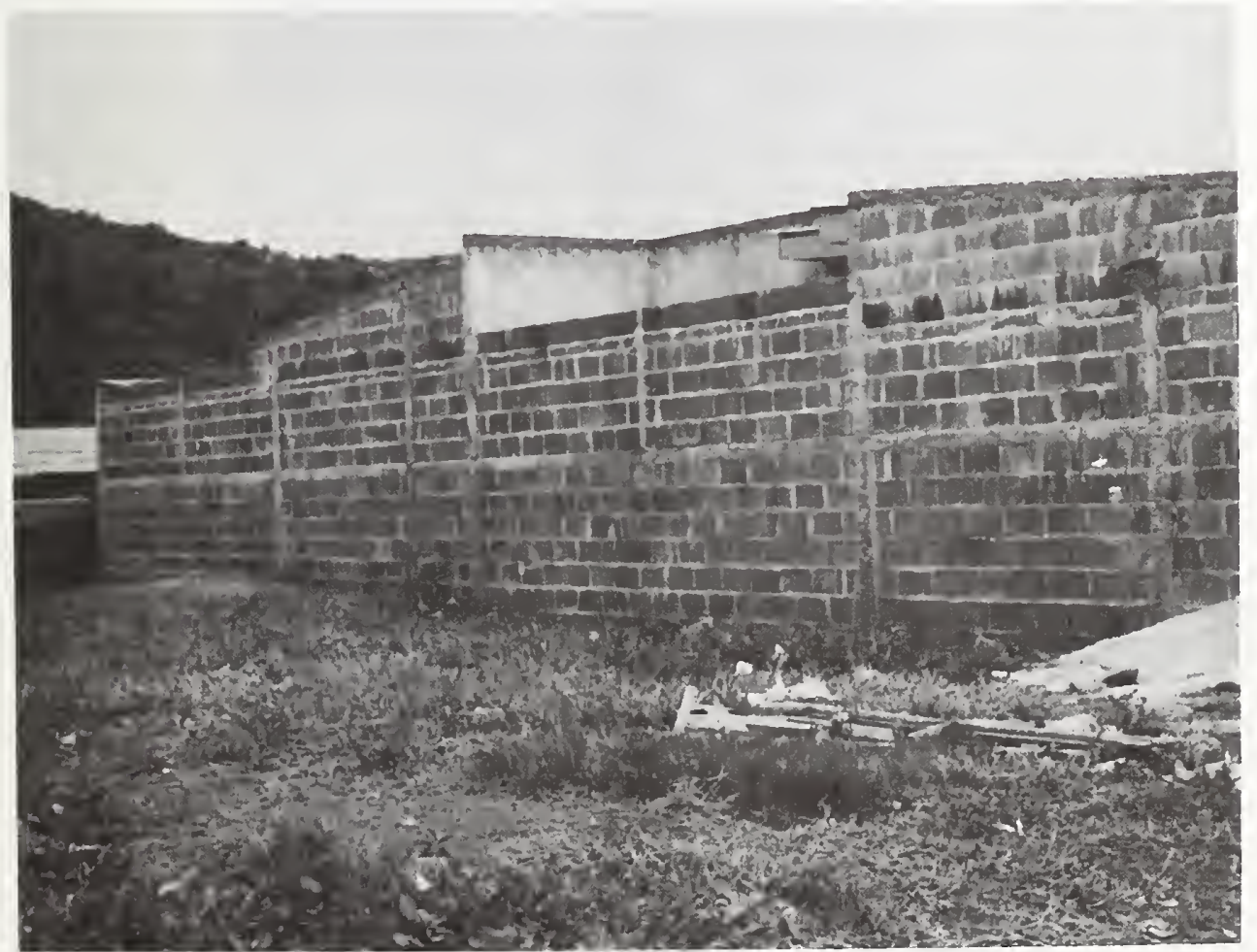




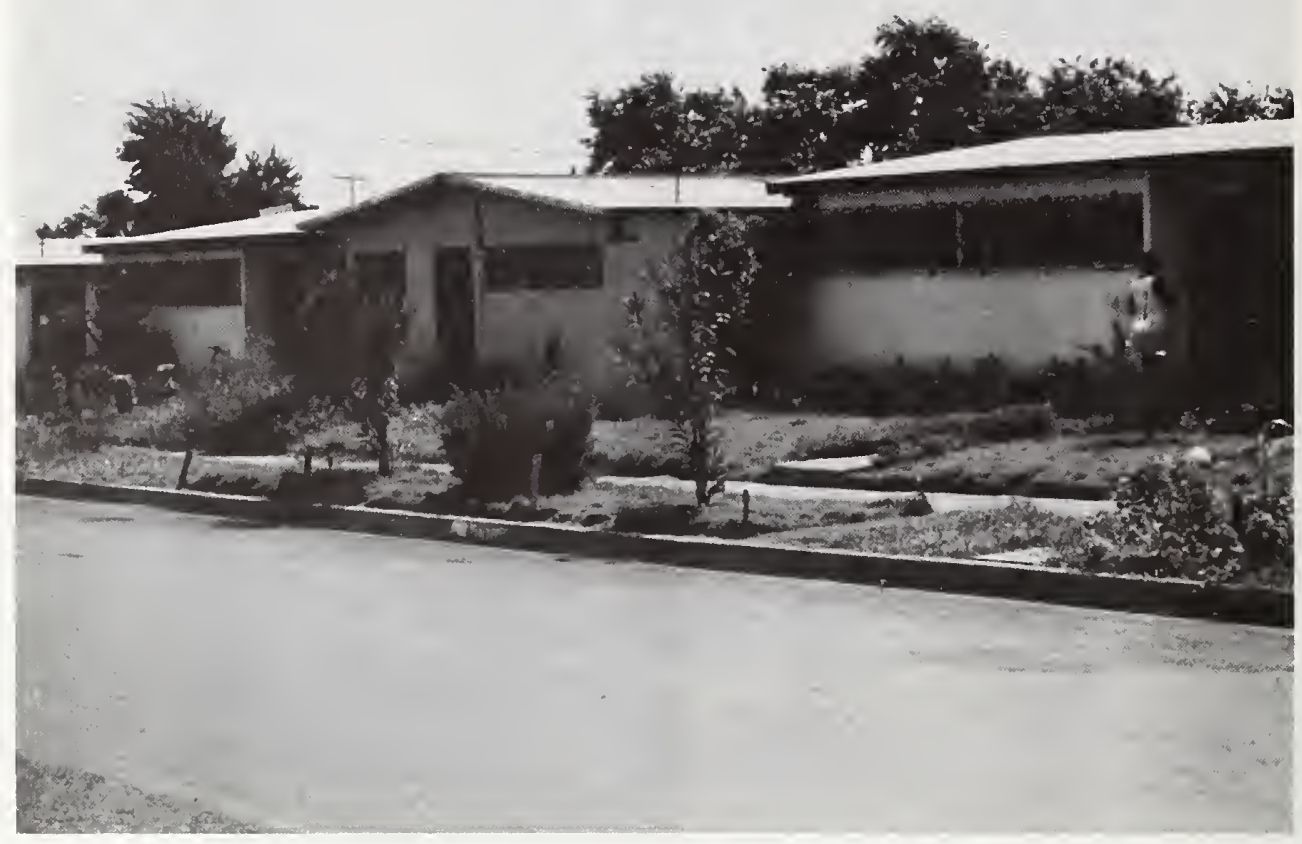

Figure 4: Las Brisas, alternate concrete panel type (failed) and reinforced masonry (in use) houses.

Figure 5: Las Brisas, detail of panel separations at connections.

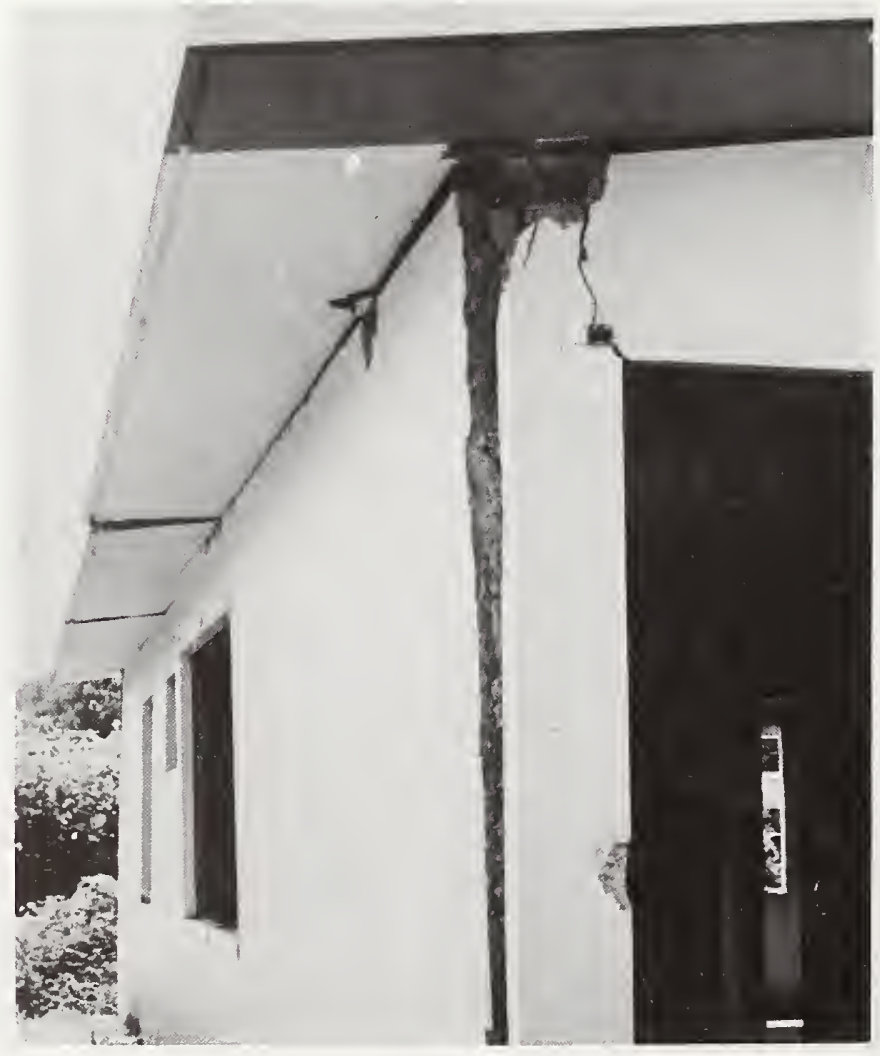




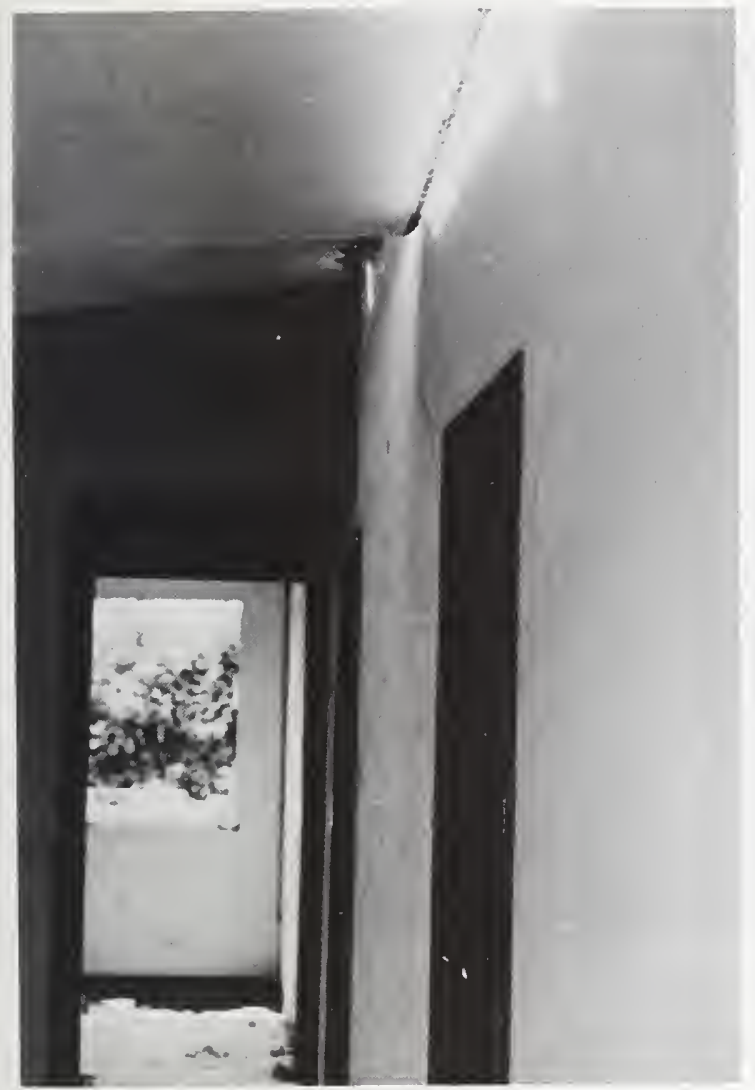

Figure 6: Las Brisas, displaced roof panel.
Figure 7: Las Brisas, joint where interior partition was displaced.

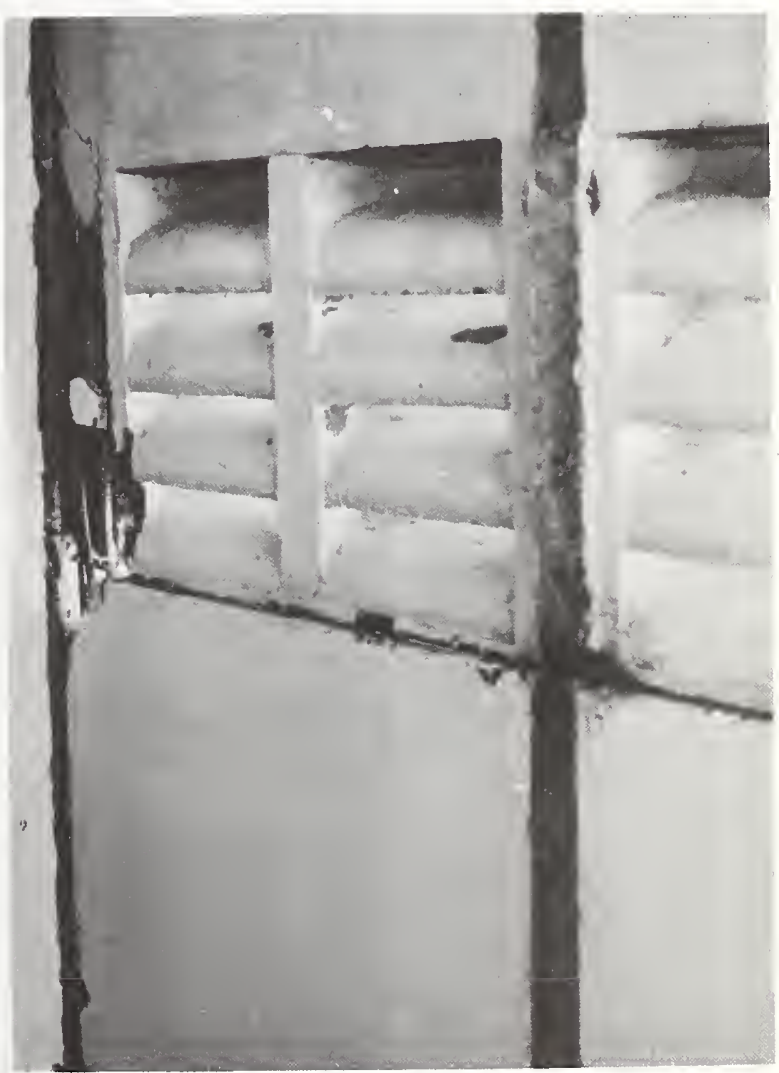




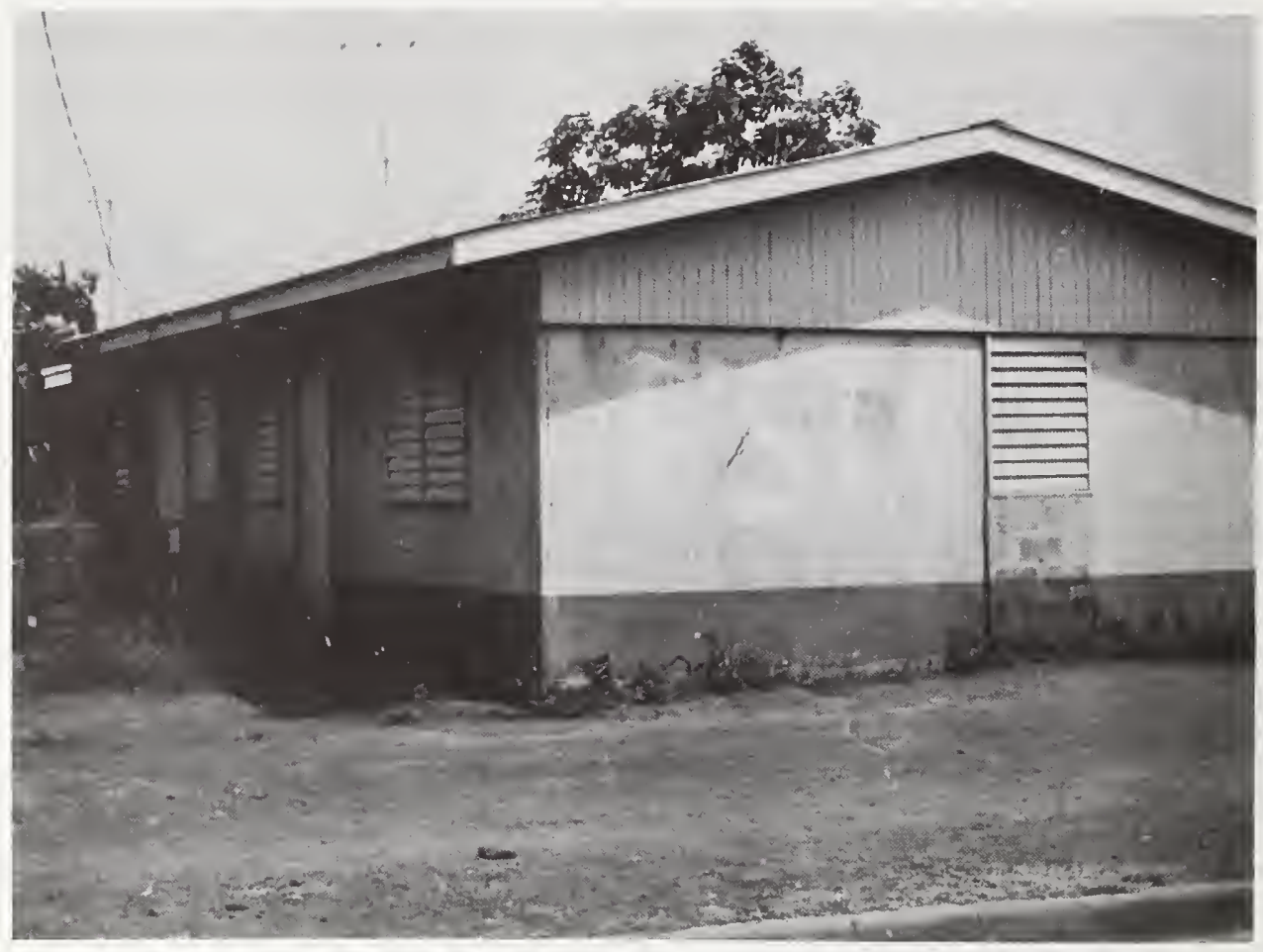

Figure 8: Colonia Francisco Morazan, cracking representative of greatest observed damage.

Figure 9: Colonia Francisco Morazan, cracked wa]1.

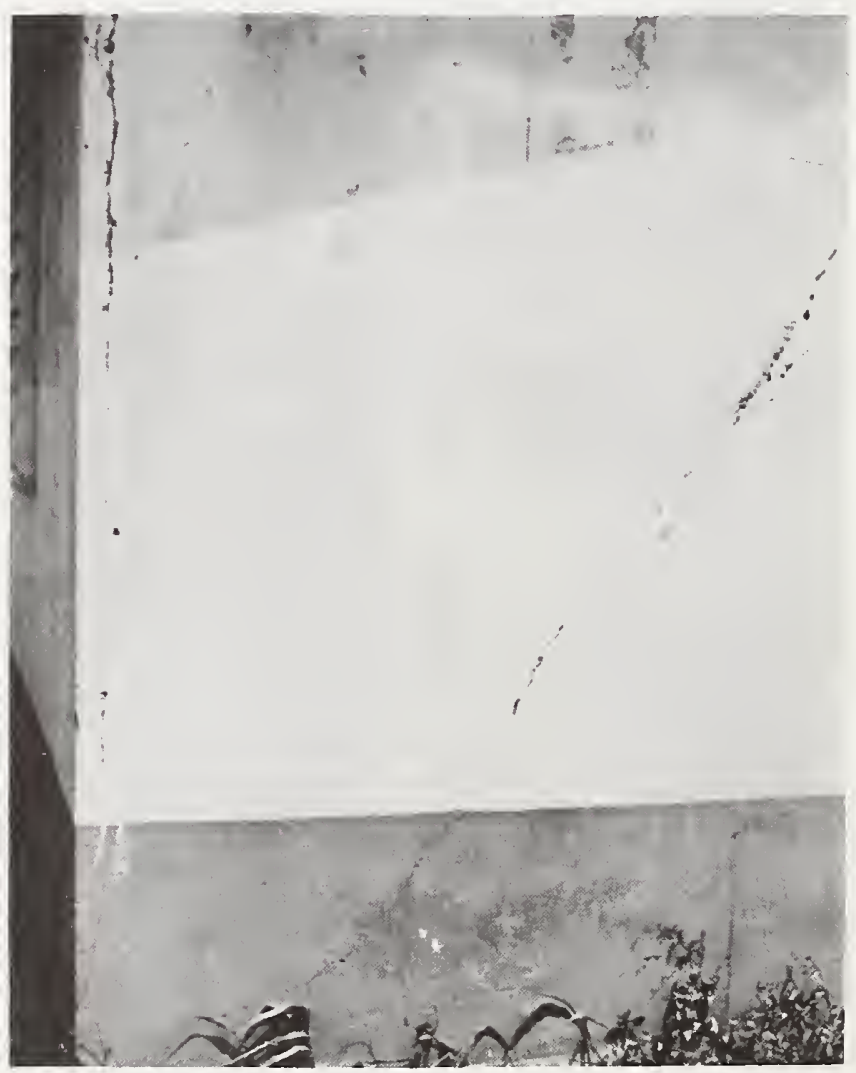




$$
7
$$




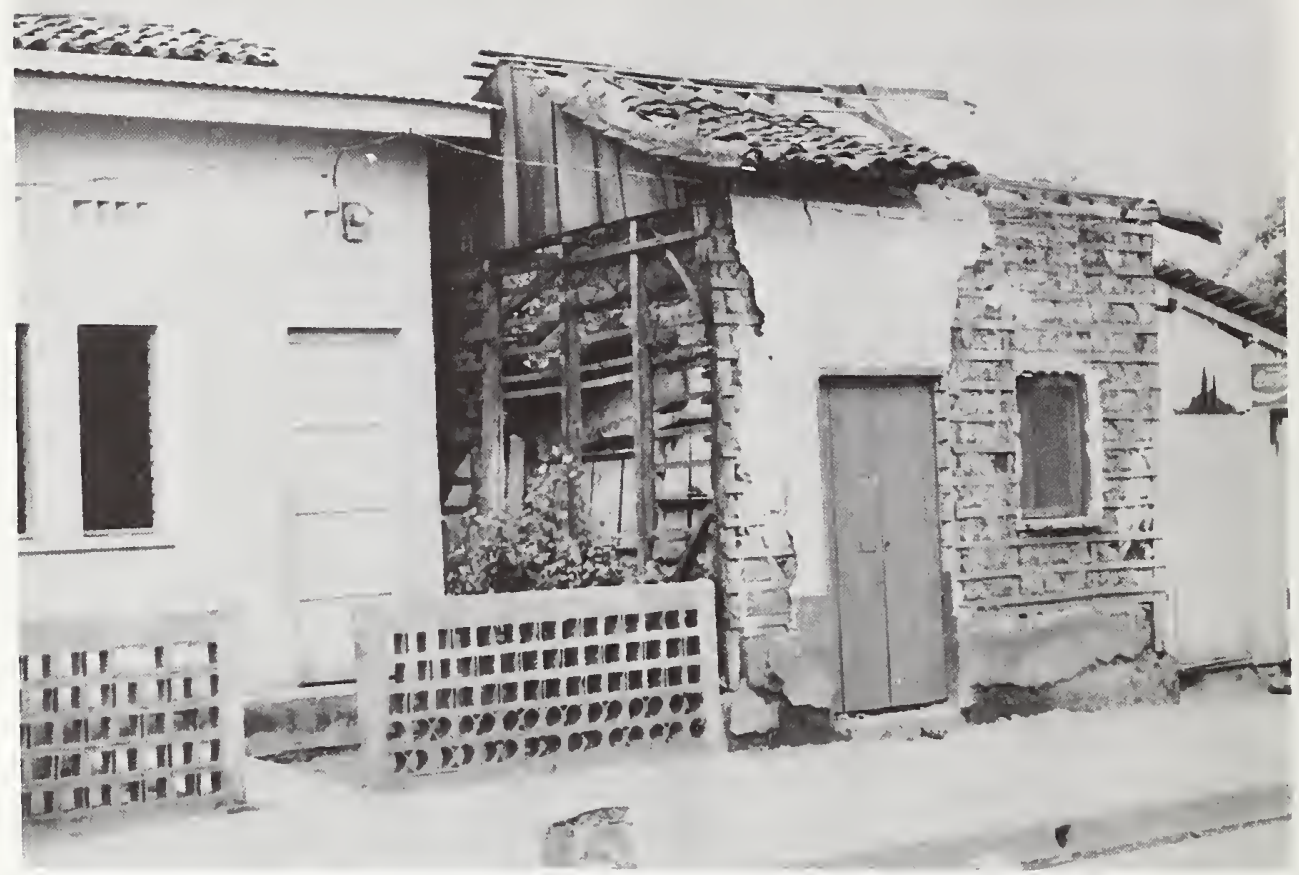

Figure 11: Barrio Monsenor Lezcano, most taquezal severely damaged or collapsed.

Figure 12: Barrio Monsenor Lezcano, varied performance of masonry construction.

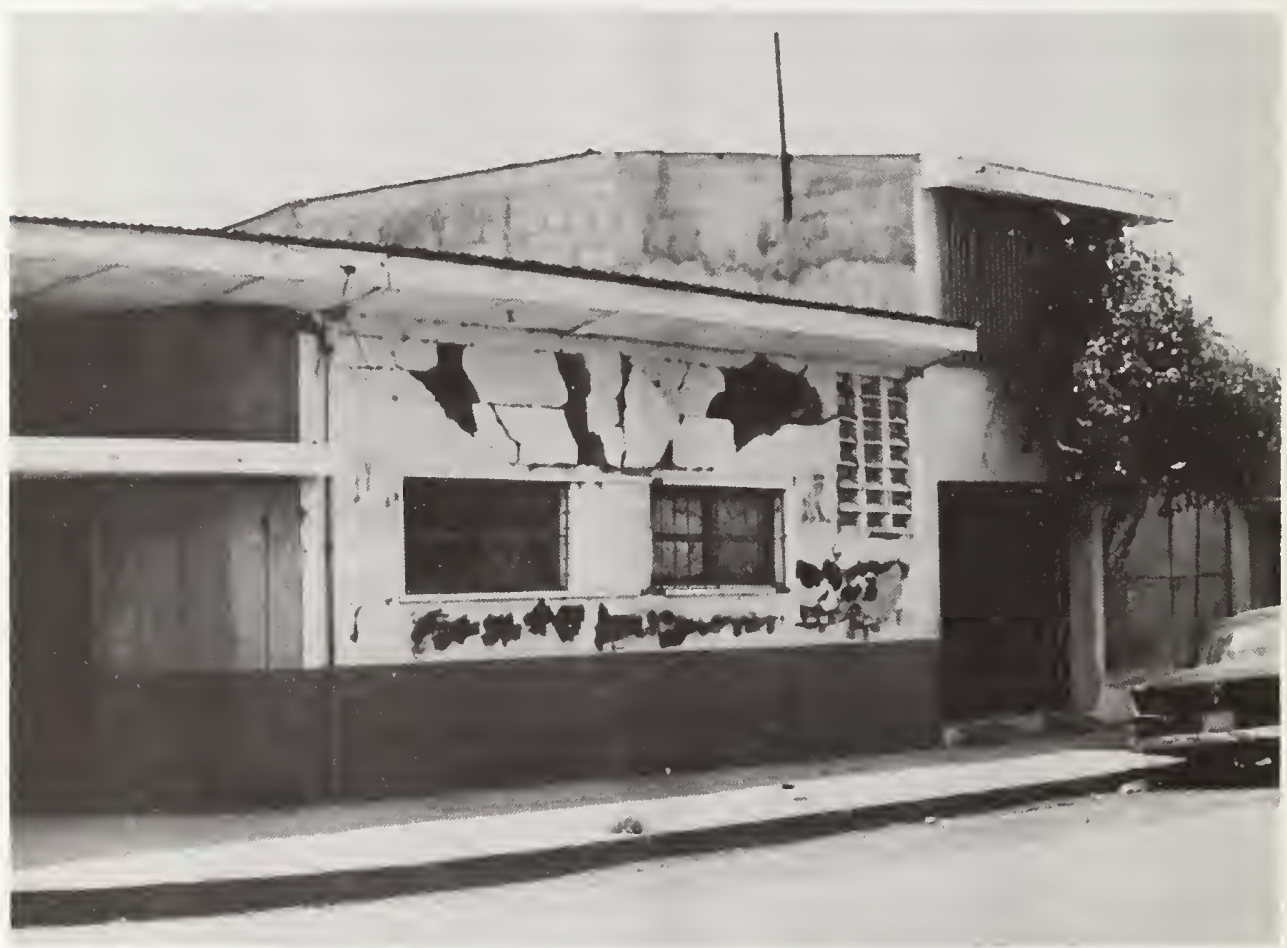




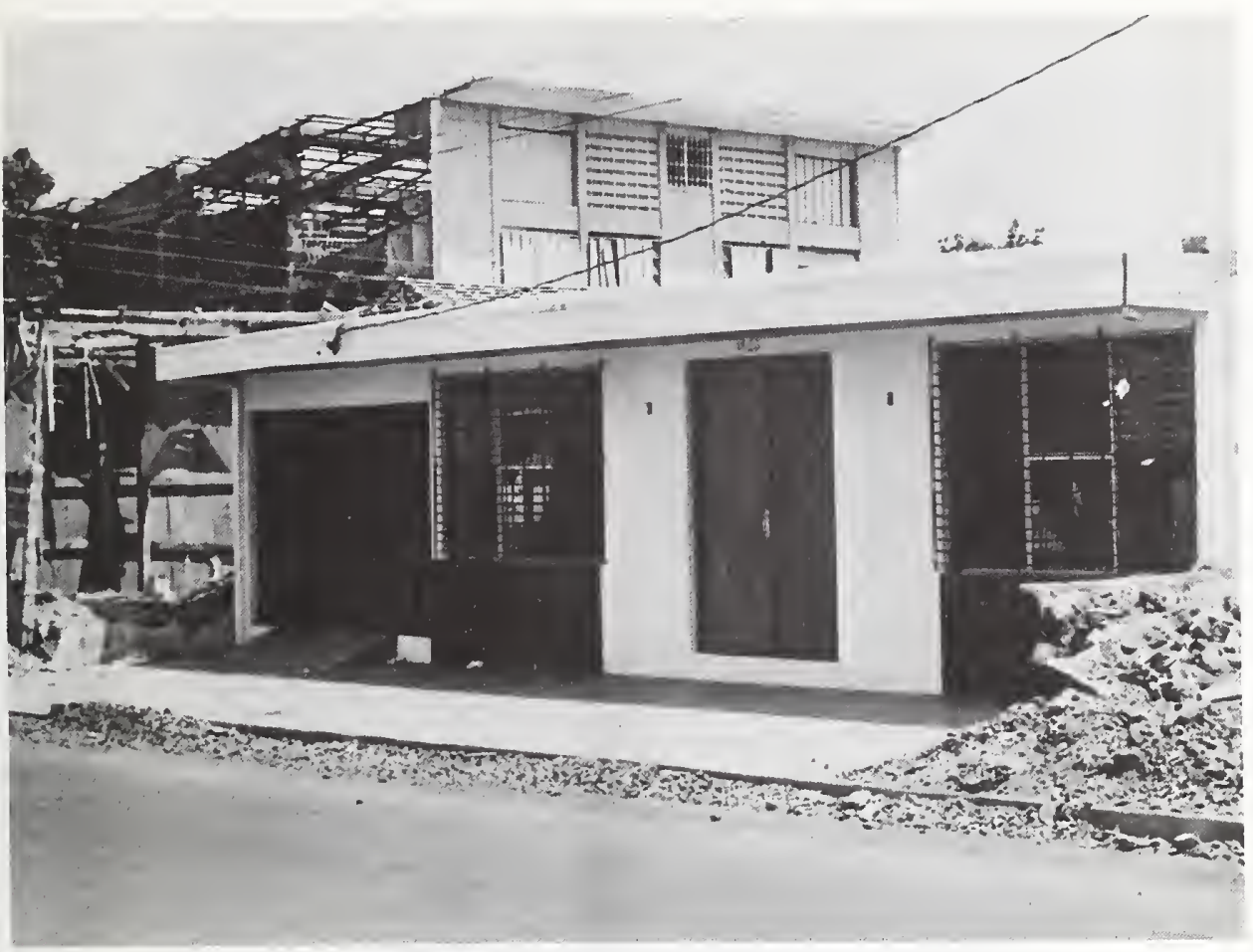

Figure 13: Barrio Monsenor Lezcano, mix of sound and collapsed buildings.

Figure 14: Barrio Monsenor Lezcano, close up of damaged masonry.

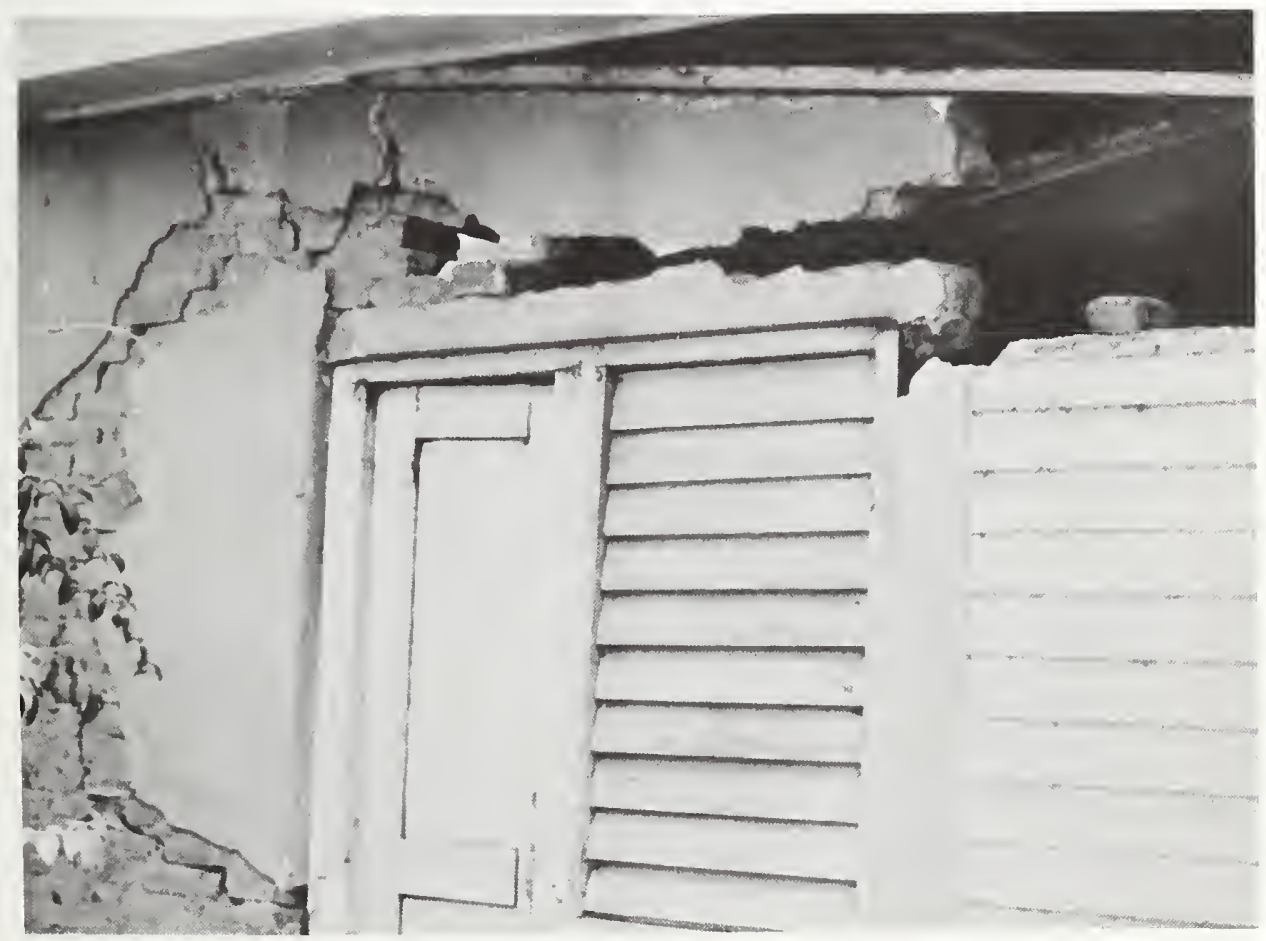


Type of Housing : lower income, self-help

Size : one story

Date of Construction: 1960

Financing : INVI

Location : D on figure 1

This is an aided-self-help housing project [6]. The corners and wall panels of full height are tilt up poured reinforced concrete, masonry block infills are used below windows, roofs are corrugated metal or wood framing. Performance is generally good, the infilled, unkeyed masonry panels tended to crack and sometimes fall in out-of-plane flexure. The corner panels often showed a diagonal crack at about $2 / 3$ height. An example of greater than average damage appears in figure 15. Occupants were pleased with the housing performance and showed pride of construction; they reported shaking had been severe enough to damage plumbing fixtures. Added rooms including second stories, figure 16, performed quite wel1. Nearby taquezal construction was severely damaged.

Housing Performance

COLONIA MAXIMO JEREZ

Inspection Date: 11 July 1973

Inspected by : Craig Noren

R. N. Wright

Type of Housing : lower middle income

Size : one story

Date of Construction: 1967

Financing : INVI

Location : E on figure 1

These are light roofed, one-story houses with two types of walls. One type uses a reinforced concrete end frame with members about 6 in square, perhaps cast in place, with precast panels inside the frame, figure 17. Similar construction occurs in Colonia 14 de Septiembre. These walls were substantially damaged, figure 18 and 19. Some construction joints between frame members had no continuity, the precast panels separated because of inadequate anchorage. The other type of wall in unframed concrete at corners, enough to expost reinforcement and the full thickness of wall. These damages appear more easily repairable. In general, houses in this colonia had light to substantial, but repairable, damage.

Housing Performance

ALTAMIRE D'ESTE

Inspection Date: 11 July 1973

Inspected by: Craig Noren

R. N. Wright

Type of Housing : upper middle income

Size : varied, one or two stories

Date of Construction: 1969 and later

Financing

Location

In general, the substantial houses in this area survived well with some 1 ight damage. The collapsed reinforced masonry house, figure 27 , designed and occupied by an engineer, shows a stenciled sign blaming the builder for the failure. 


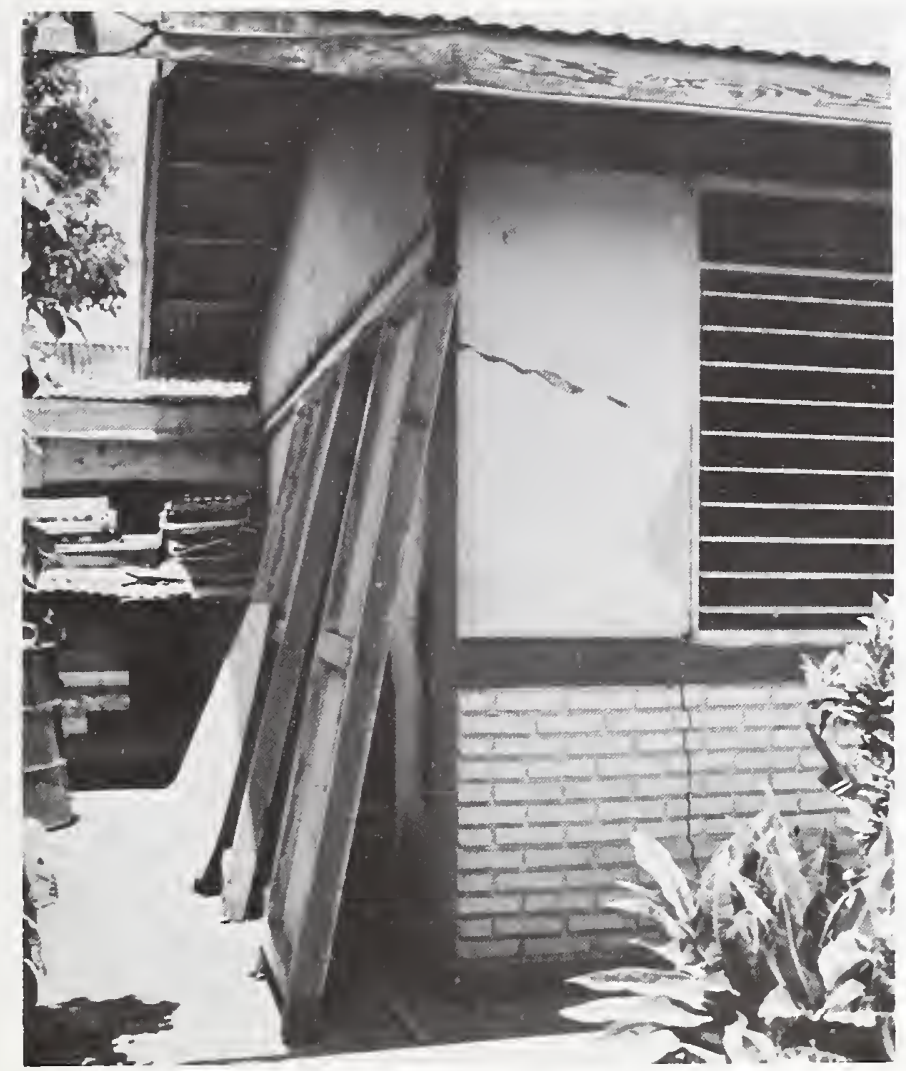

Figure 15: Colonia Managua, damage limited to cracking in poured concrete corner.

Figure 16: Colonia Managua, additions, even of second stories, survived.

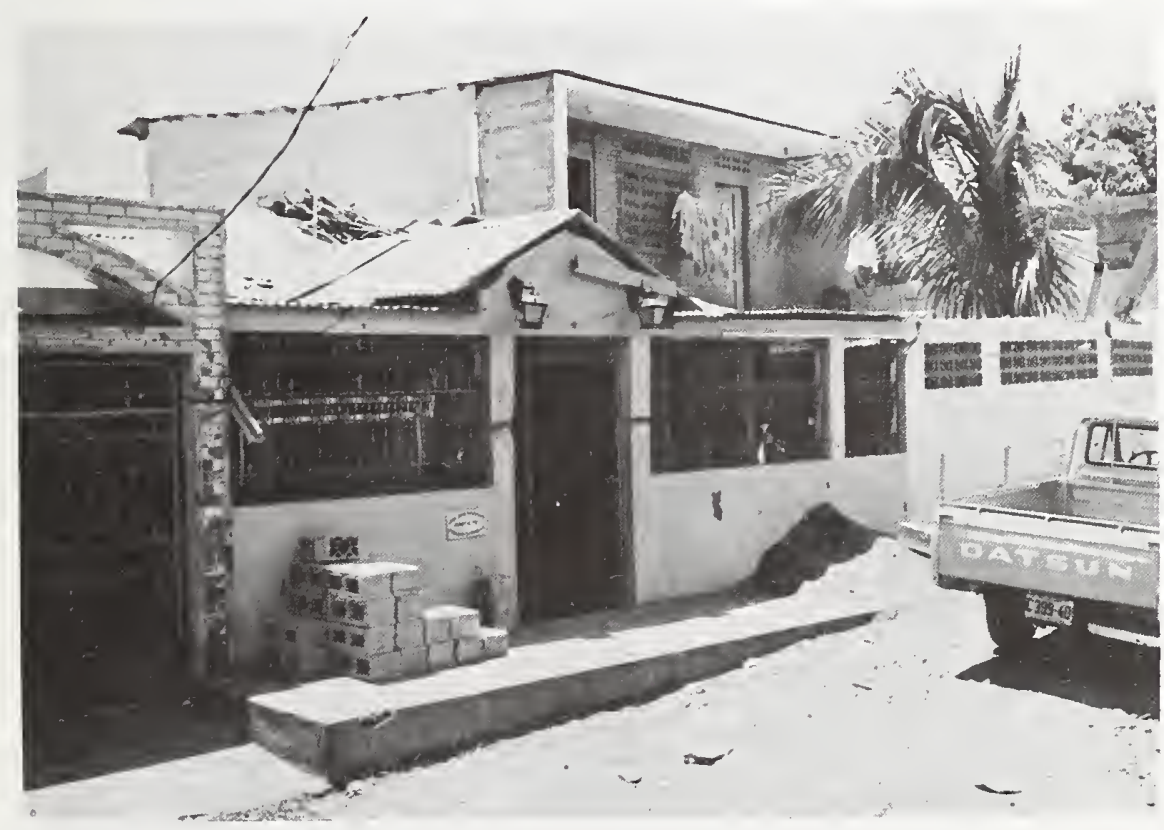




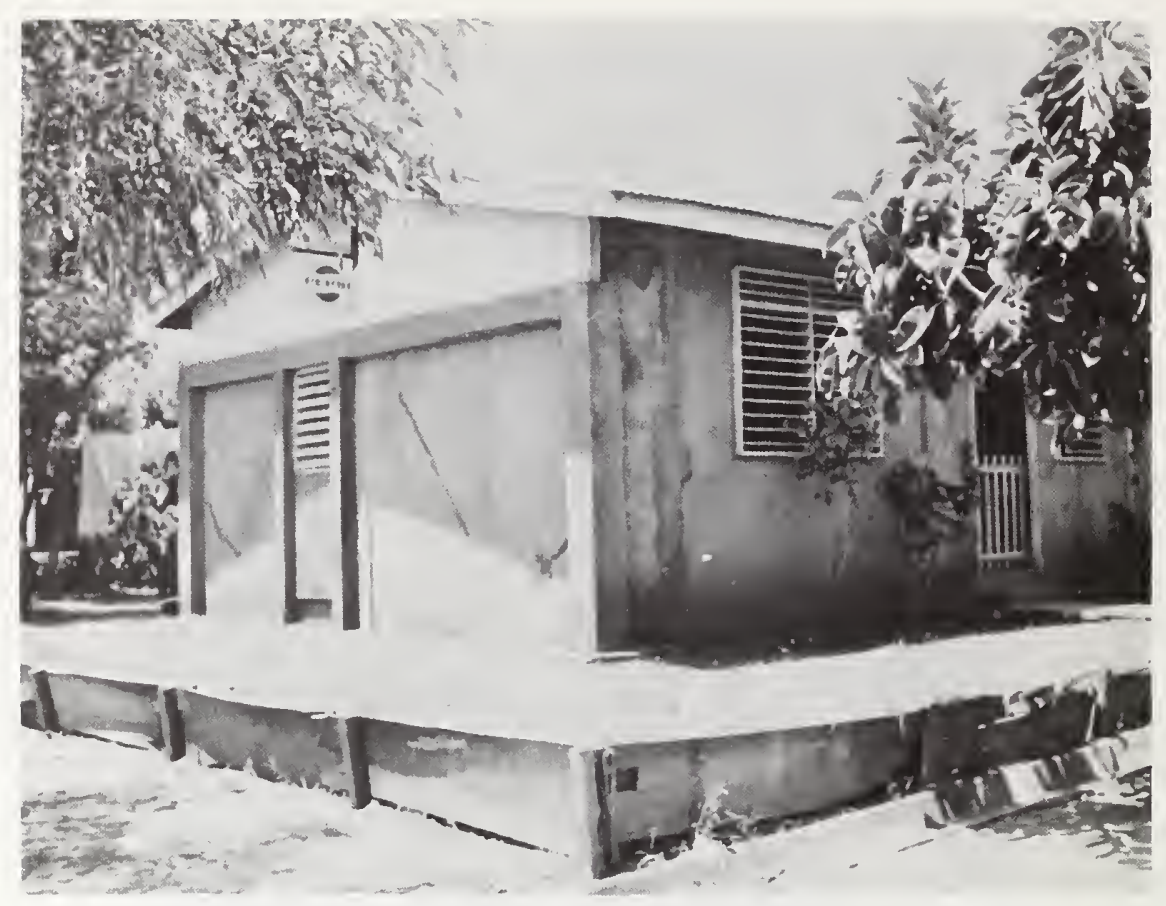

Figure 17: Colonia Maximo Jerez, less damaged frame-panel units.

Figure 18: Colonia Maximo Jerez, separation of frame and panels.

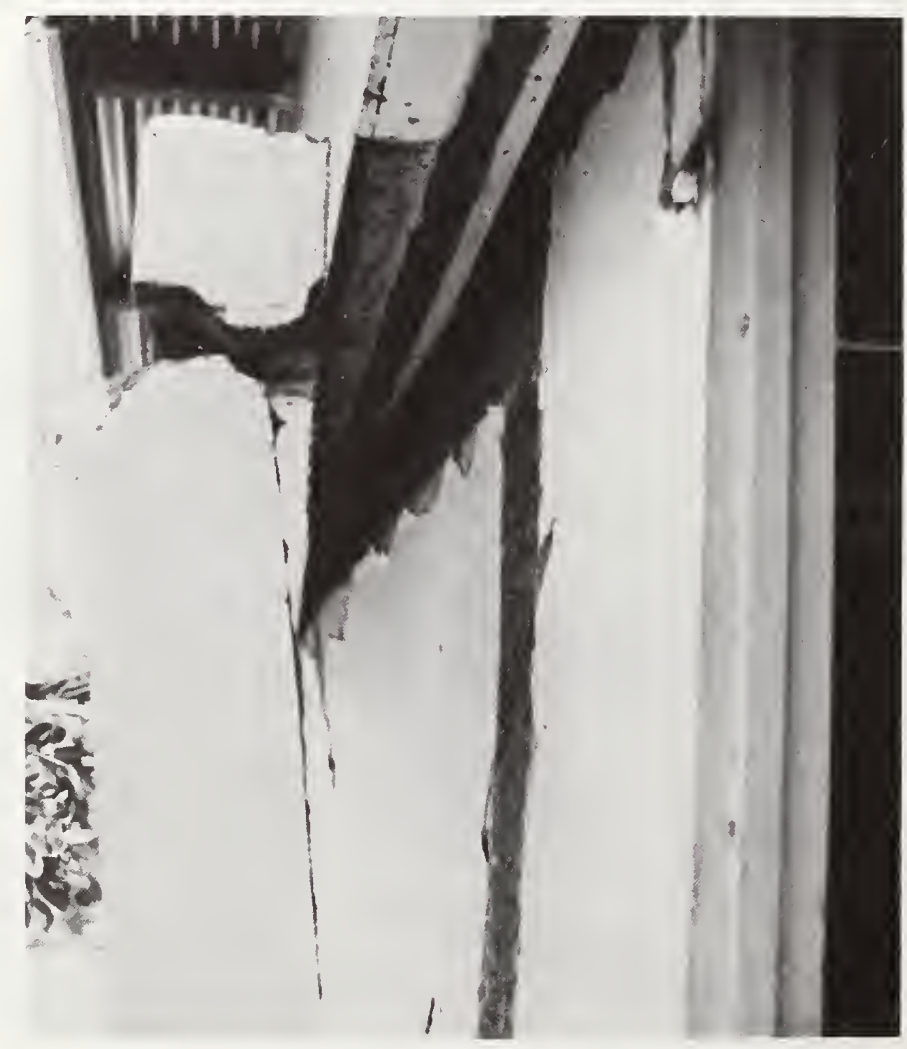




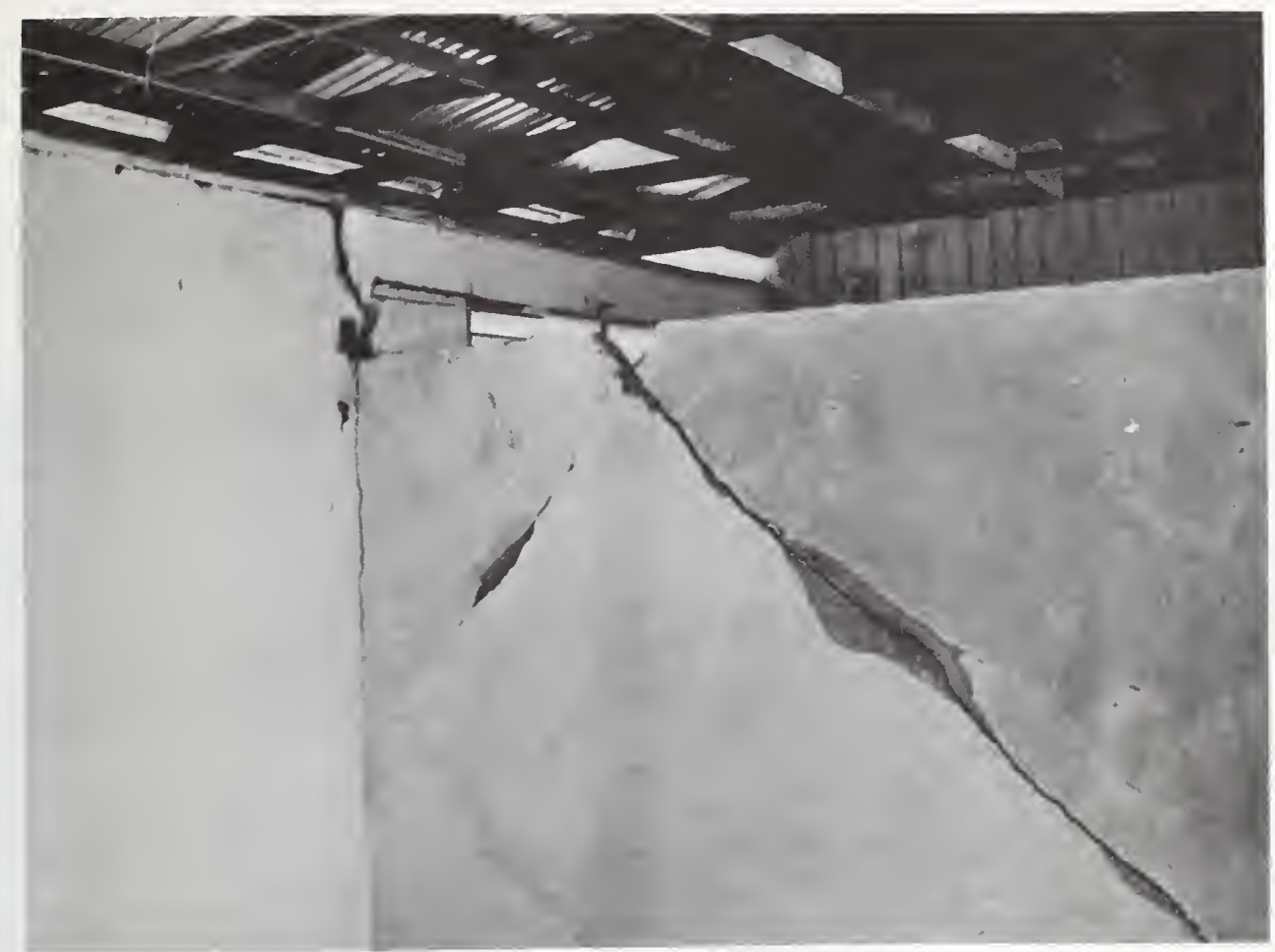

Figure 19: Colonia Maximo Jerez, damage to interior and exterior panels.

Figure 20: Colonia Maximo Jerez, unframed units showed some cracking at corners.

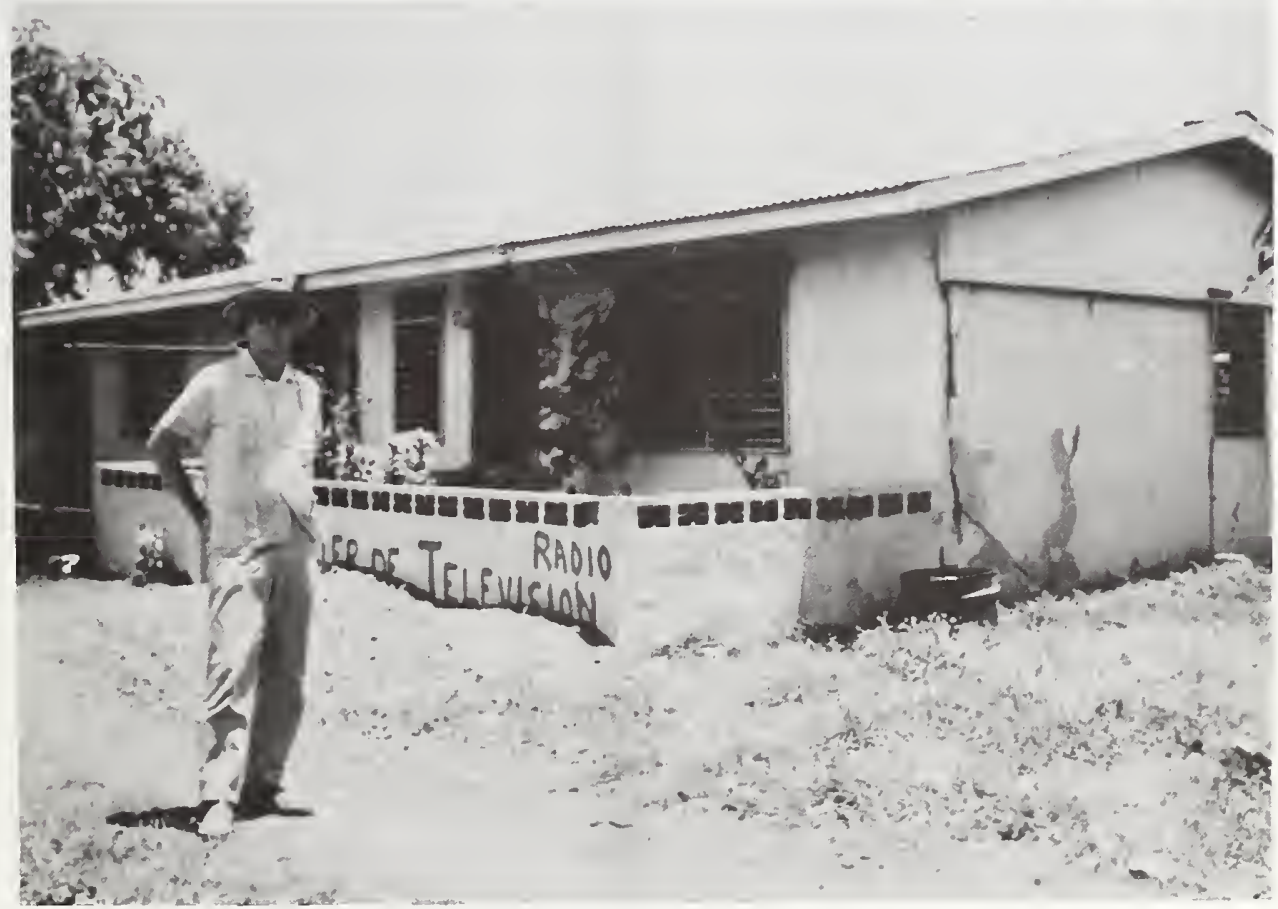




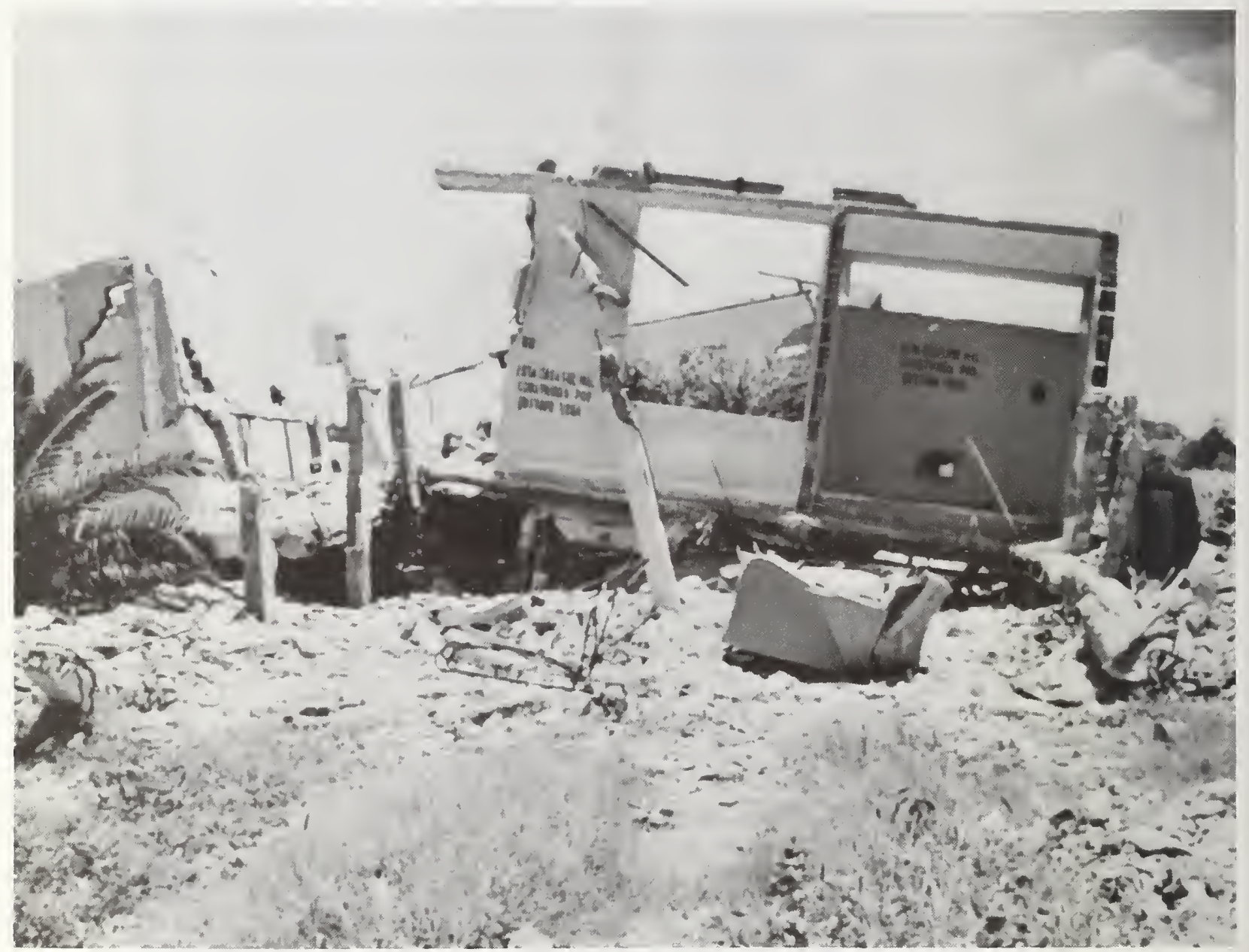

Figure 21: Altamira d'Este, the stencil is the owner-designer blaming the builder. 
Housing Performance

BOSQUES DE ALTAMIRA

Inspection Date: 11 July 1973

Inspected by : Craig Noren

R. N. Wright

Type of Housing : middle income

Size : one story

Date of Construction: 1970 and later

Financing : CABEI with HIGO

Location : G on figure 1

In this area the intensity of shaking was sufficient to topple free standing, one meter high masonry walls. These houses use corrugated metal roofs on steel framing set into the exterior and interior masonry walls. These walls are tile reinforced with bond beams and columns. Many houses show 1 ittle or no damage, a few are severely cracked as a result of poor details of reinforcement.

Housing Performance

LOS ROBLES

Inspection Date: 11 July 1973

Inspected by: Craig Noren

R. N. Wright

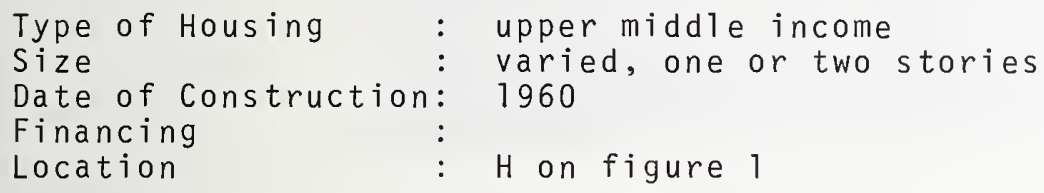

Damage varied from none visible to collapse. A collapsed two-story house of tile walls reinforced with concrete bond beams and columns shows poor anchorage of reinforcing; the dimensions and details were not apparent for the collapsed first story structure, figure 22. Roofing had been salvaged; it appeared to have been tile on a wood frame. The range of performance from negligible damage, figure 23, to collapse indicates the importance of good building practices.

Housing Performance

COLONIA LUIS SOMOZA

Inspection Date: 11 July 1973

Inspected by : Craig Noren

R. N. Wright

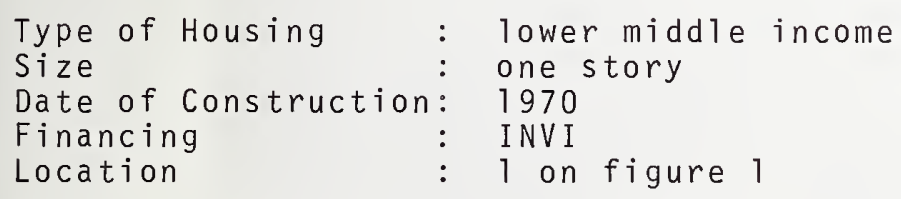

The walls are concrete block reinforced by concrete bond beams and columns. The interior cross wall is structural with a reinforced crown beam, figure 24. Roofing is asbestos cement on timber purlins. Damage varied from none to light cracking, figures 25 and 26. Intensity was enough to collapse free standing masonry walls and lightly reinforced masonry houses in the nearby Barrio Ducuali, figure 27. 


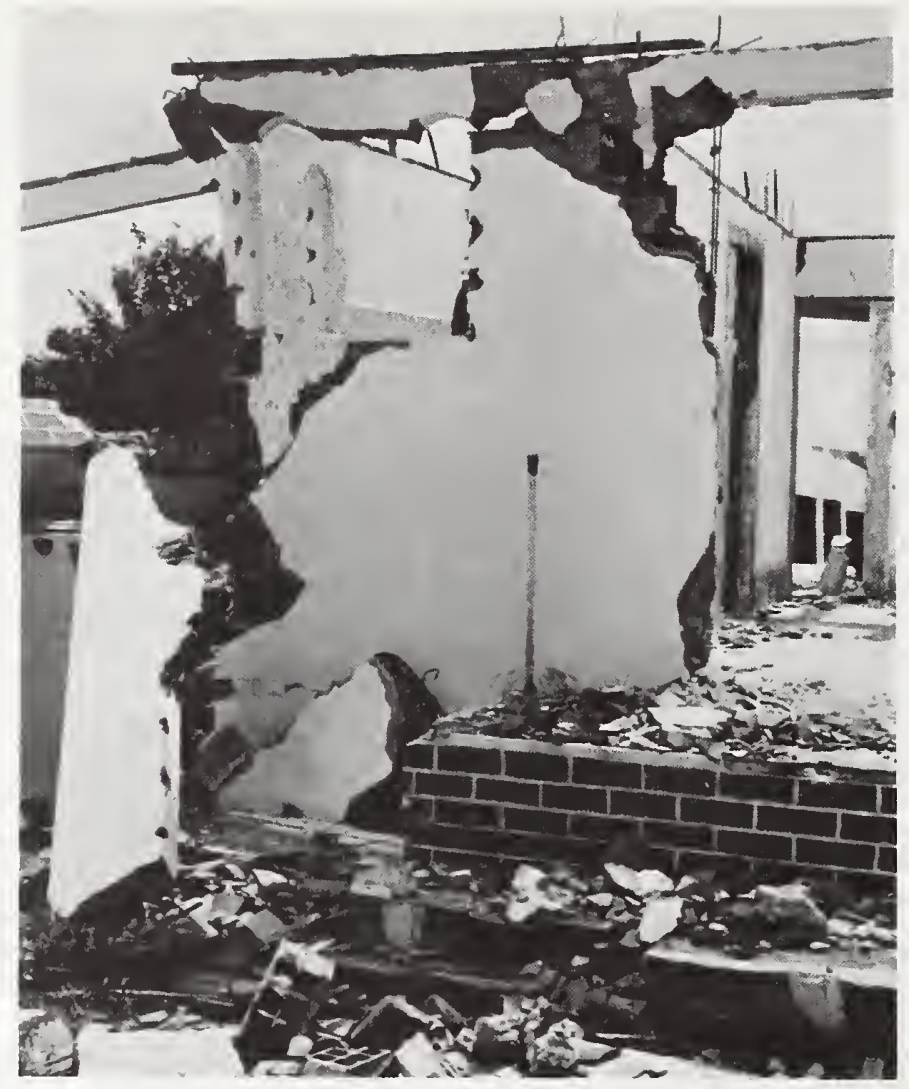

Figure 22: Los Robles, collapsed two-story house, second floor on ground.

Figure 23: Los Robles, generally good condition of neighborhood.

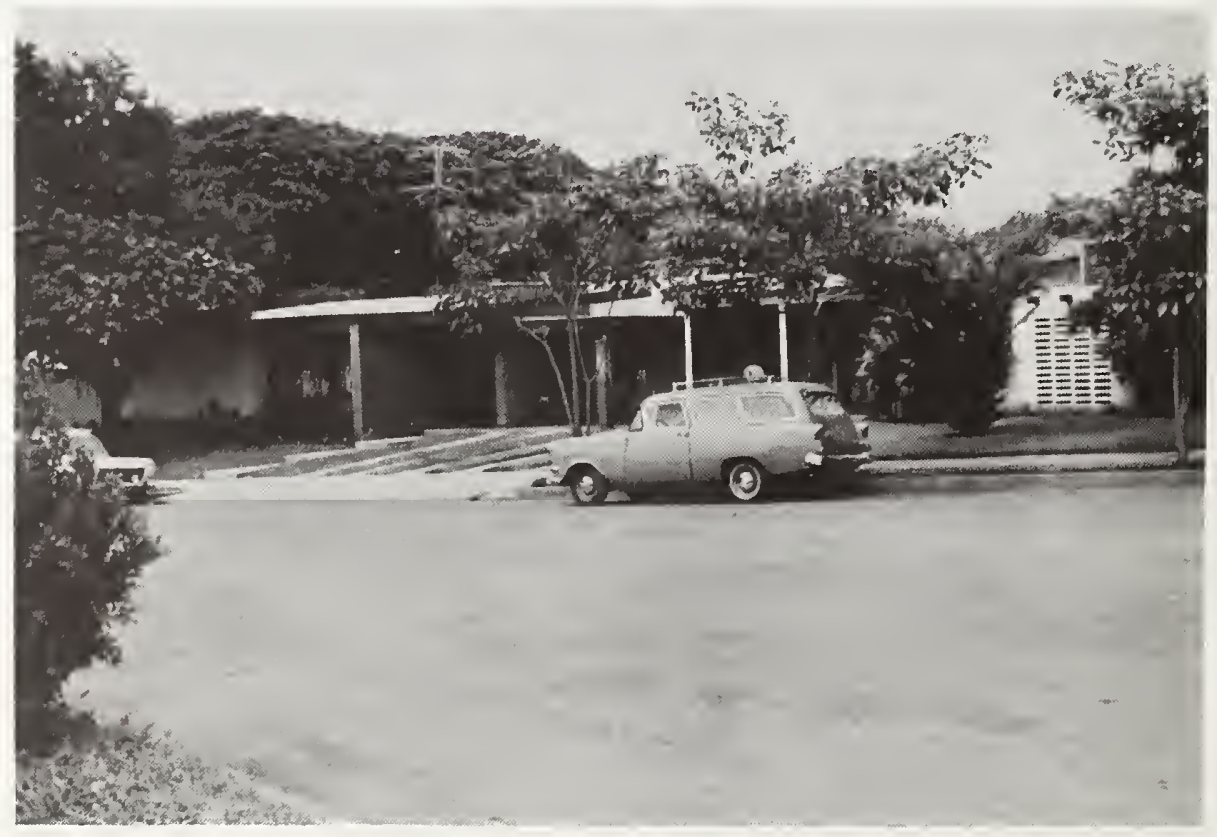




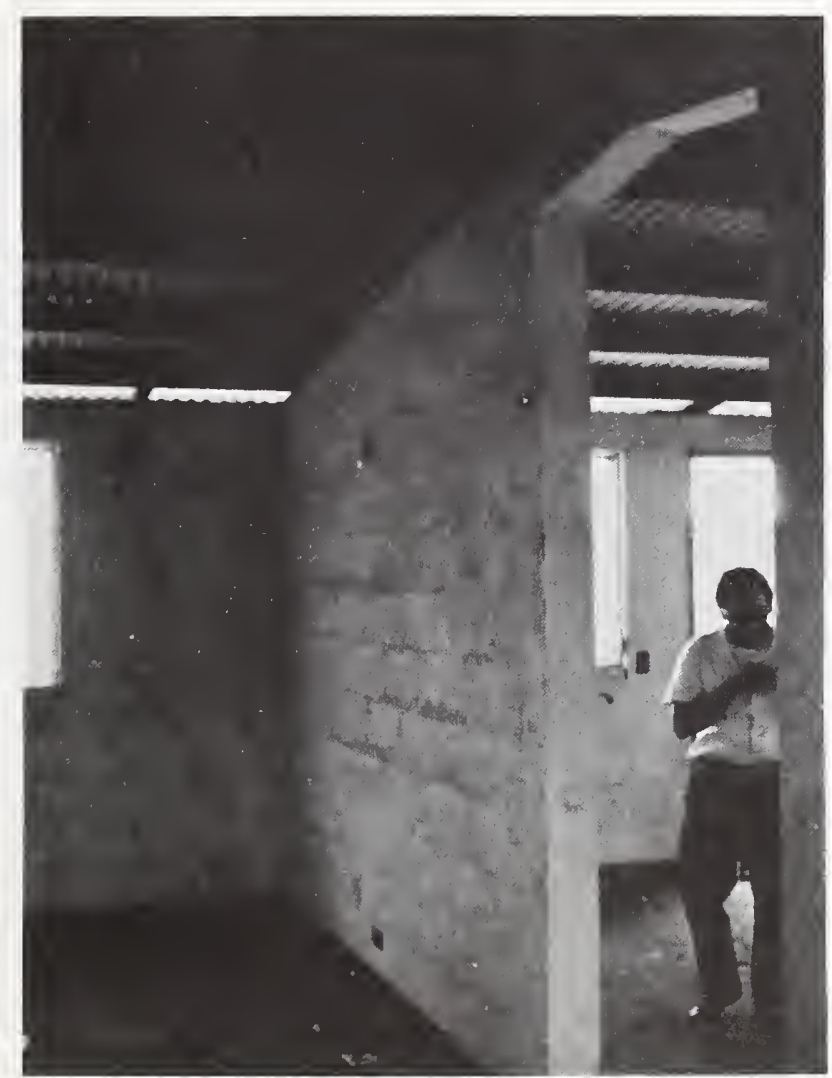

Figure 24: Colonia Luis Somoza, structural interior walls.

Figure 25: Colonia Luis Somoza, generally good condition of houses.

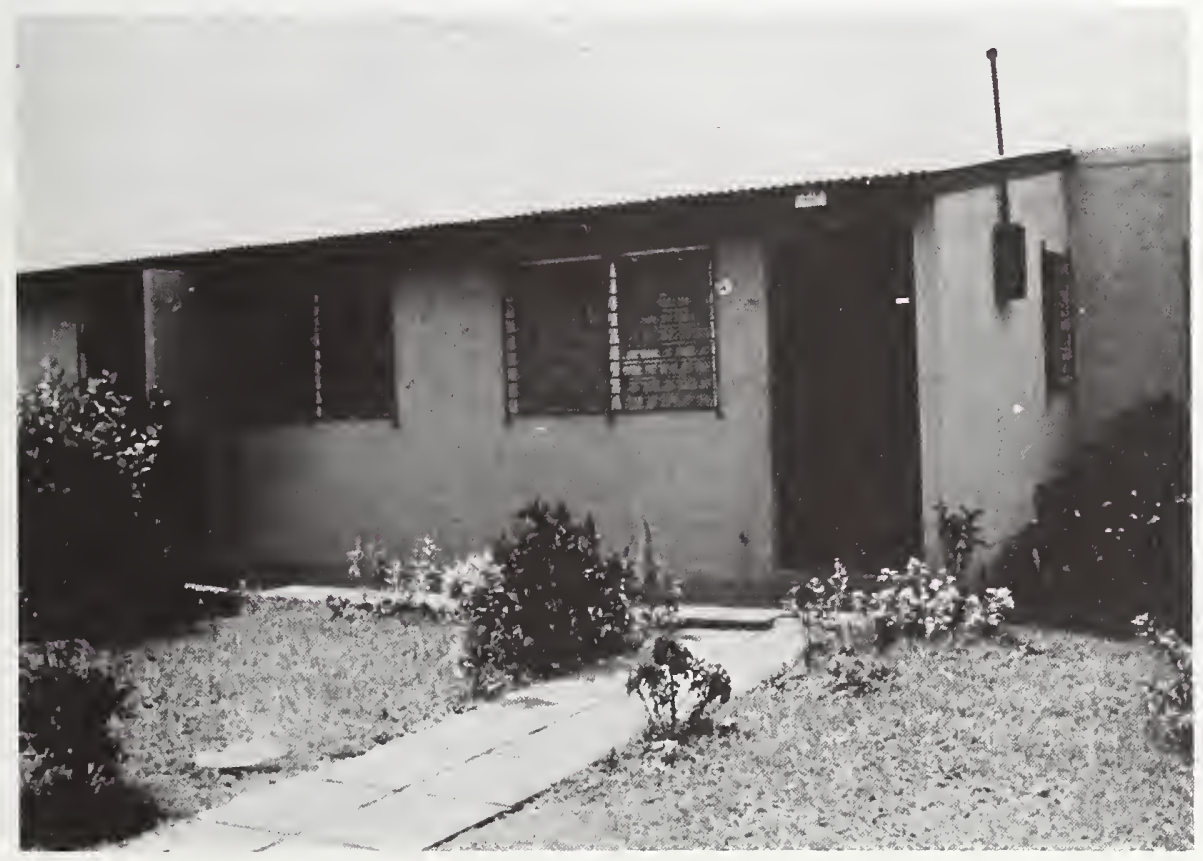




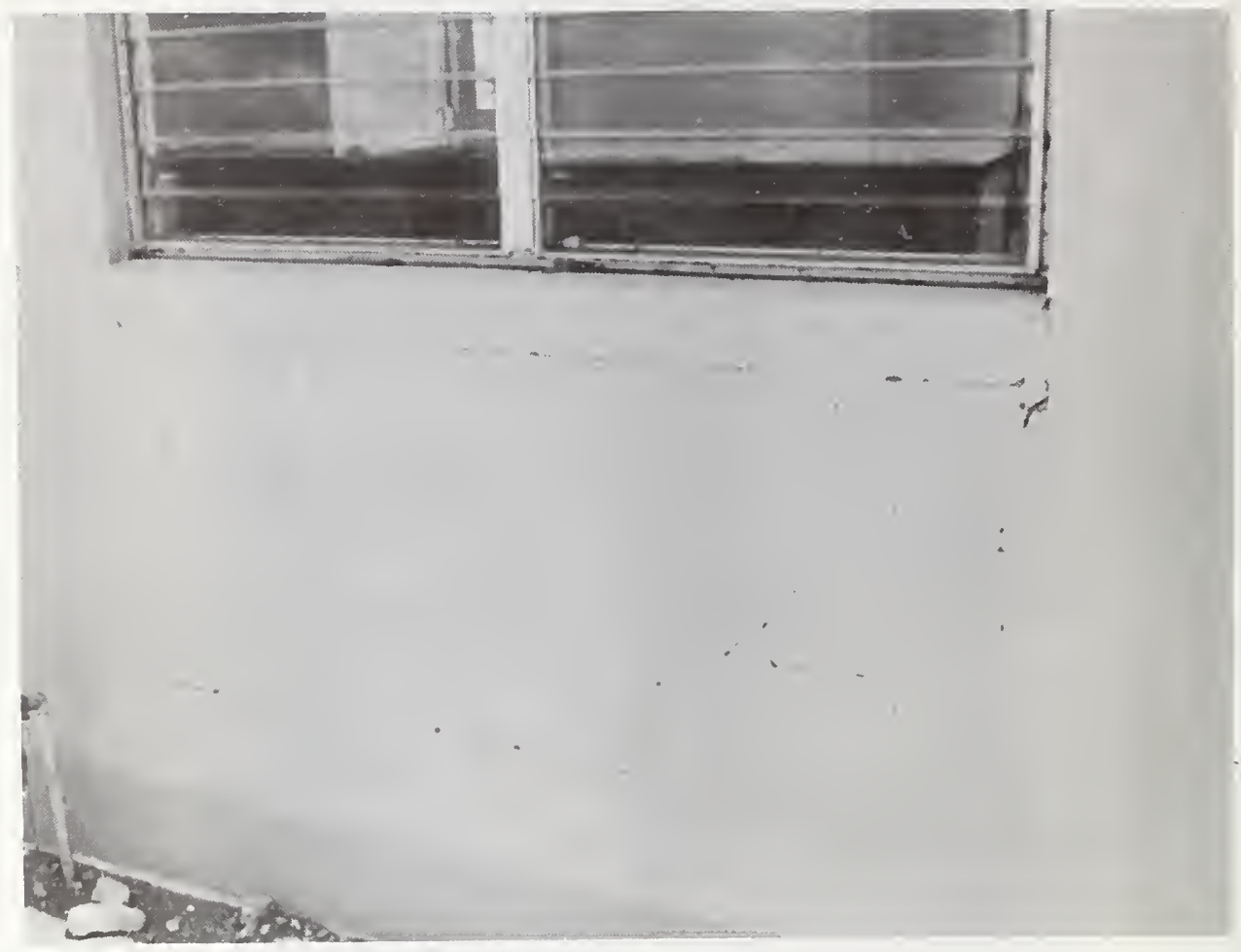

Figure 26: Colonia Luis Somoza, light cracking of blocks.

Figure 27: Barrio Ducuali, collapsed house with roof salvaged.

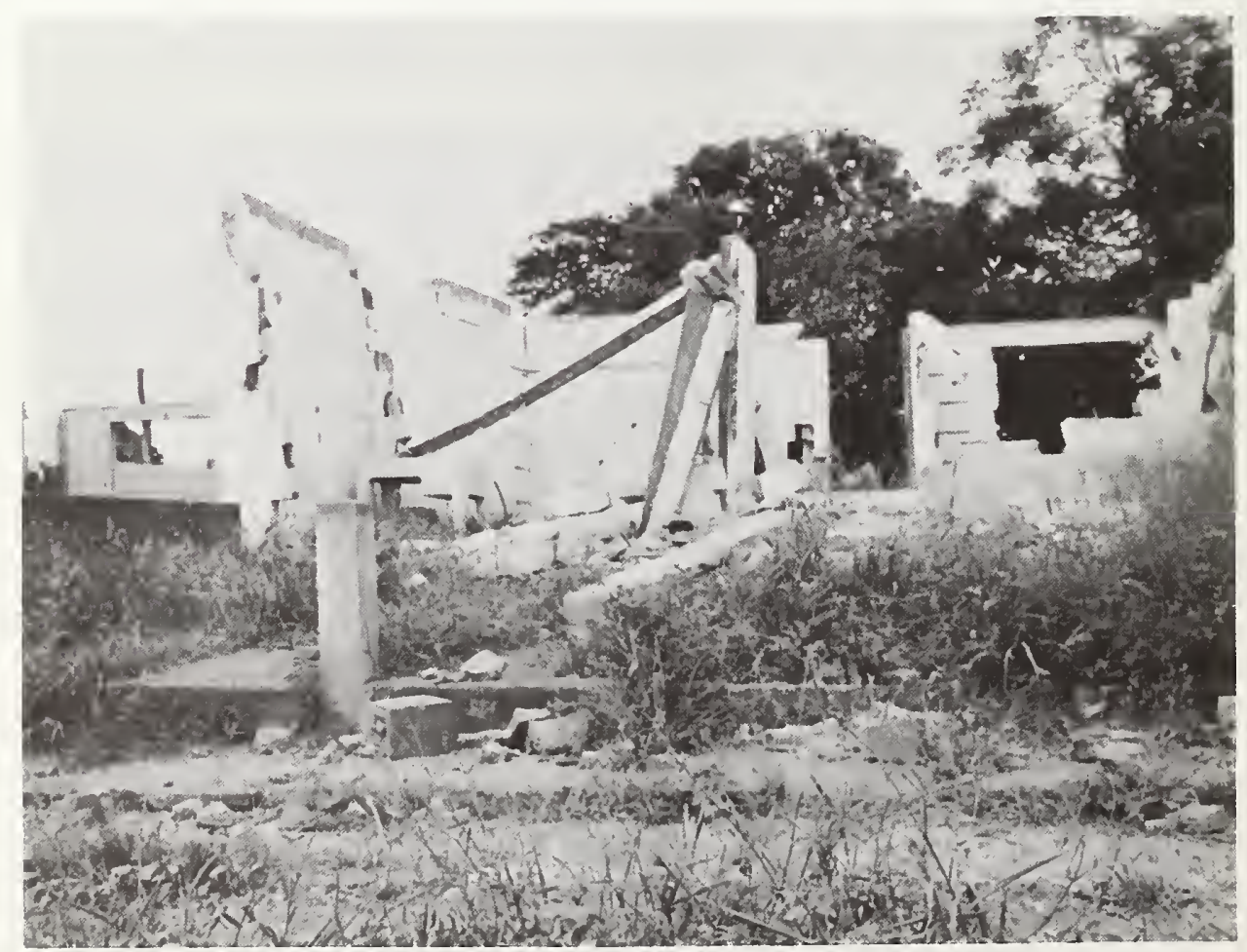


Housing Performance

COLONIA NICARAO

Inspection Date:

Inspected by :
11 July 1973

Craig Noren

R. N. Wright

Type of Housing : lower middle income

Size : one story

Date of Construction: 1960-1963

Financing : INVI

Location : J on figure 1

Roofs are corrugated metal on timber framing. Two types of walls, concrete and tile, were seen. Sound units with concrete walls are shown in figure 28. The concrete walls are 3 in thick, perhaps using precast corner elements with a field connection to the panel below window. The front walls of about onethird of these units bulged in out-of-plane flexure, figure 29. The corner is weak since 3 \#3 bars with less than 1 in effective depth are the reinforcement in the full height, figure 30. These damages are repairable cosmetically, it is difficult to achieve proper, greater than original, resistance. The units with tile walls appeared to have cavities grouted without reinforcement, figures 31 and 32. Although no collapses of these were seen, about 50 percent of these walls were severely damaged. Some occupants expressed unhappiness with the performance, indeed the quality of construction details appeared deficient.

Housing Performance
COLONIA 14 DE SEPTIEMBRE

Inspection Date: 11 July 1973

Inspected by: Craig Noren

R. N. Wright

Type of Housing : lower middle income

Size : one story

Date of Construction: 1964

Financing : INVI

Location : K on figure 1

Performance is generally better than in the adjacent Colonia Nicarao, figure 33. Most walls are concrete block reinforced with bond beams and columns, figure 34, some use end frames as in Maximo Jerez, figure 35, apparently with concrete panel walls; roofs are corrugated asbestos cement. There is damage to most homes, typically wall flexure out of its plane, figure 36 , perhaps due to unsatisfactory mortar. 


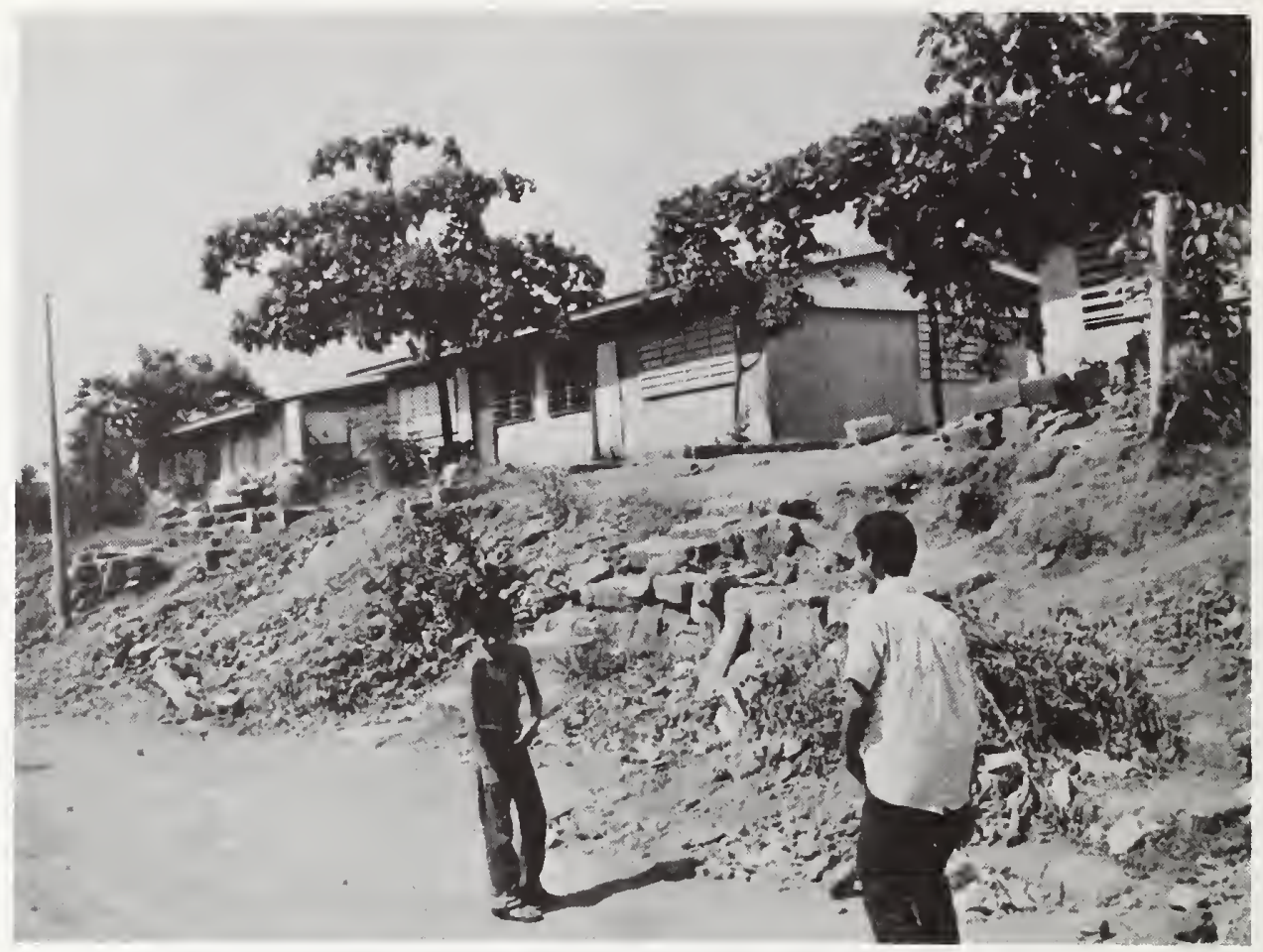

Figure 28: Colonia Nicarao, less damaged units.

Figure 29: Colonia Nicarao, bulging of front walls.

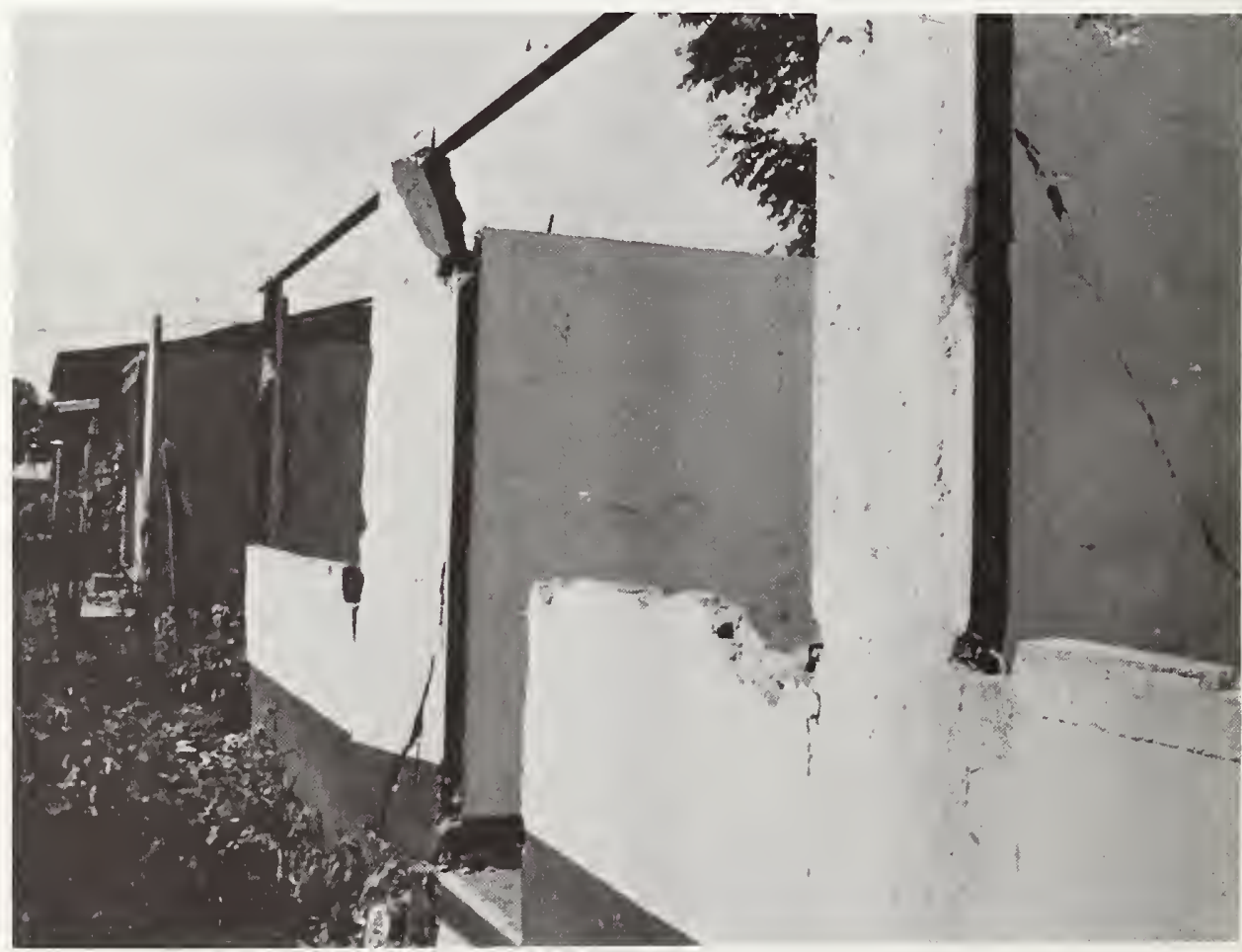




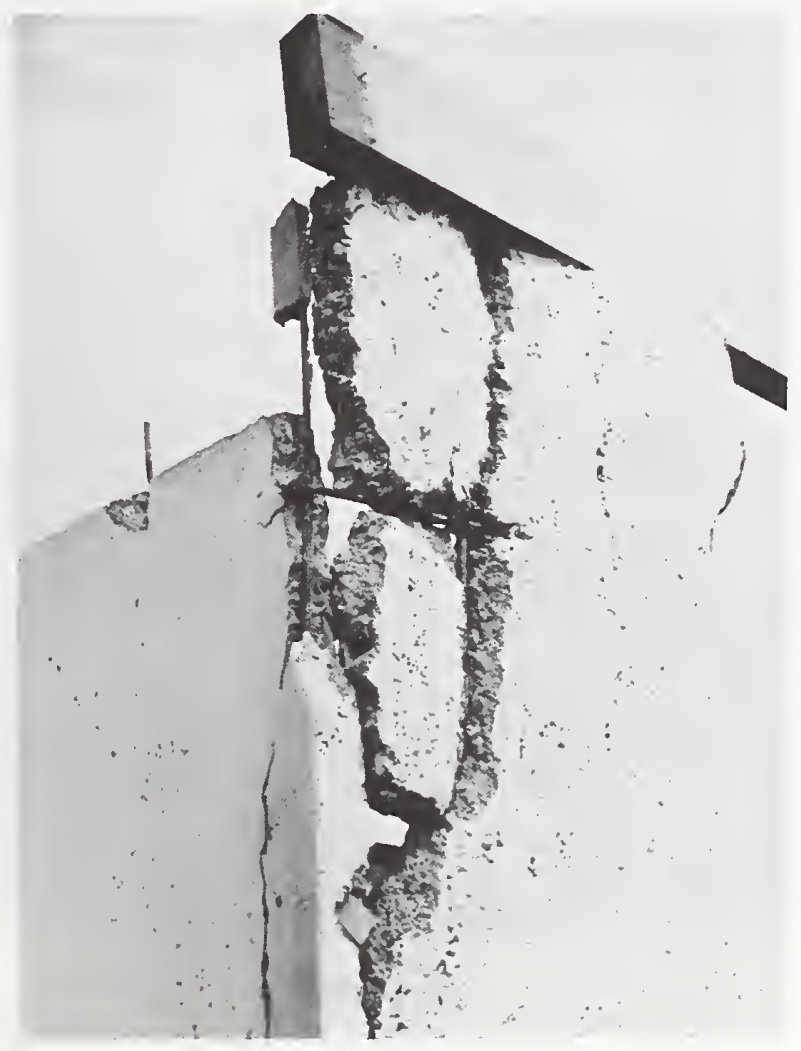

Figure 30: Colonia Nicarao, close up of corner reinforcement.

Figure 31: Colonia Nicarao, damaged grouted tile construction.

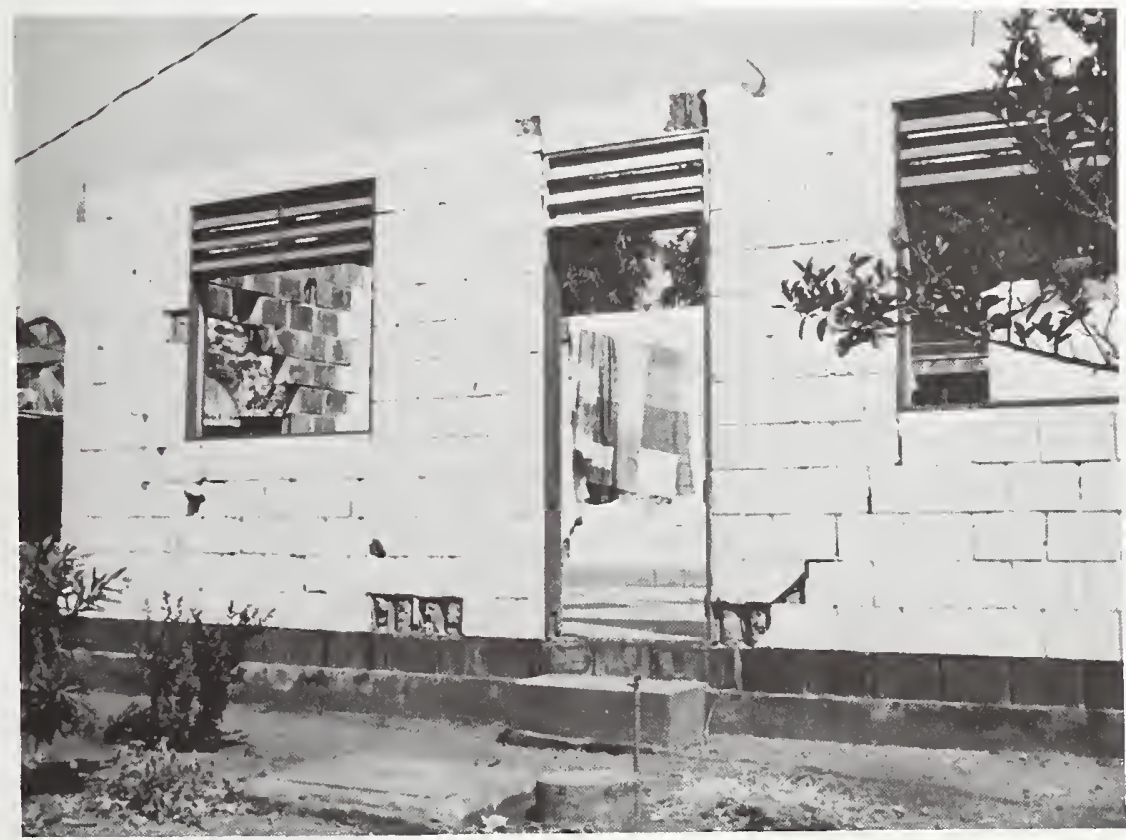




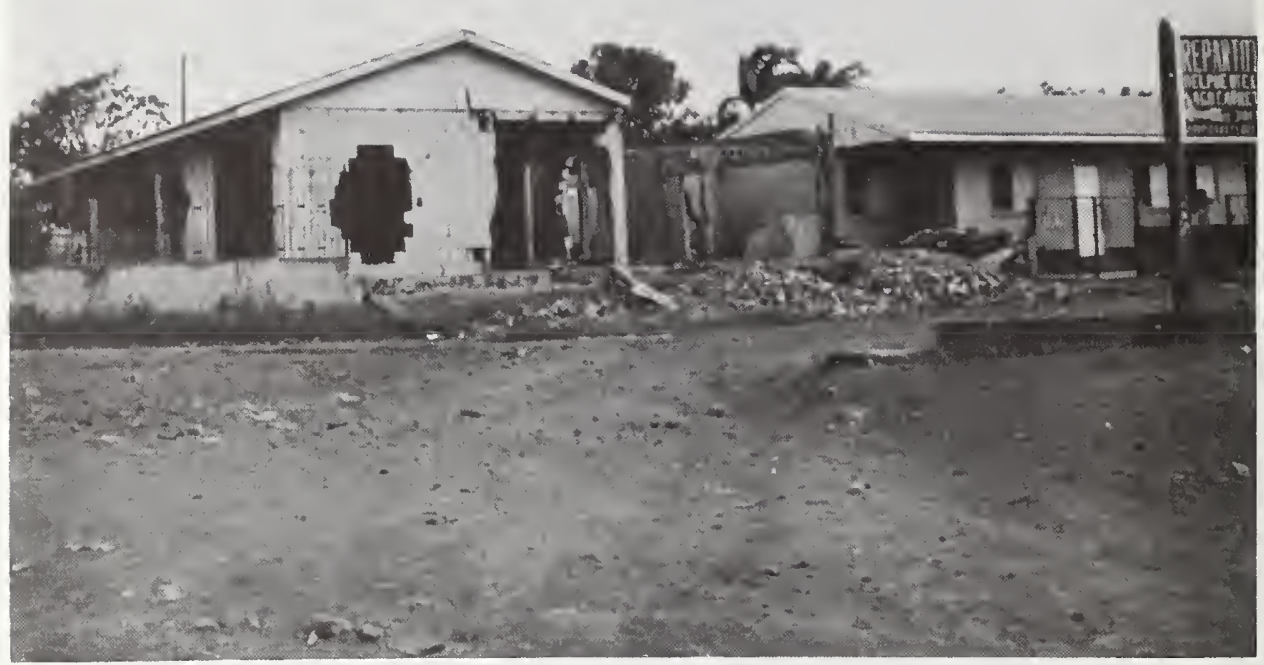

Figure 32: Colonia Nicarao, damaged grouted tile construction.

Figure 33: Colonia 14 de Septiembre from Colonia Nicarao, damage lesser in former colonia.

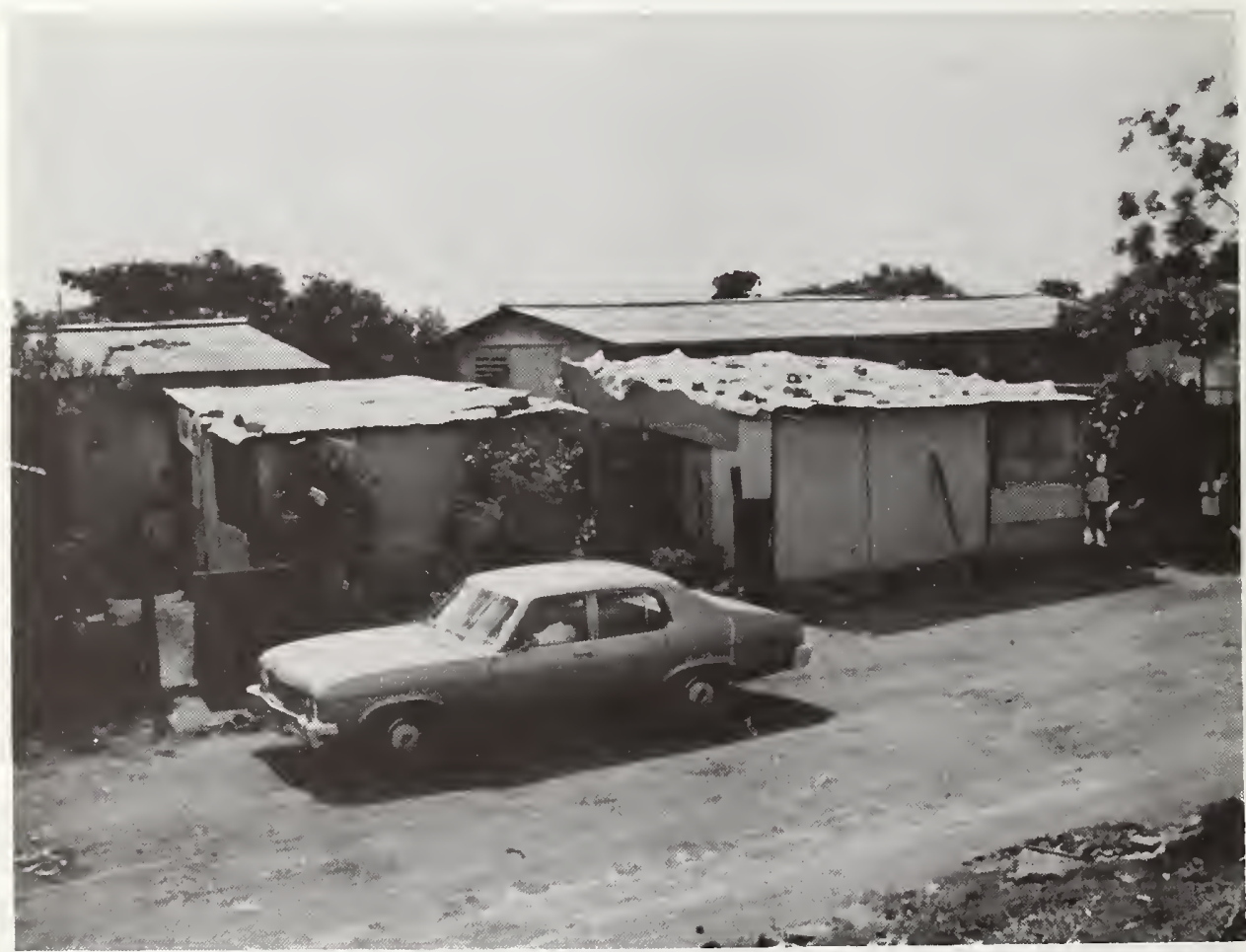




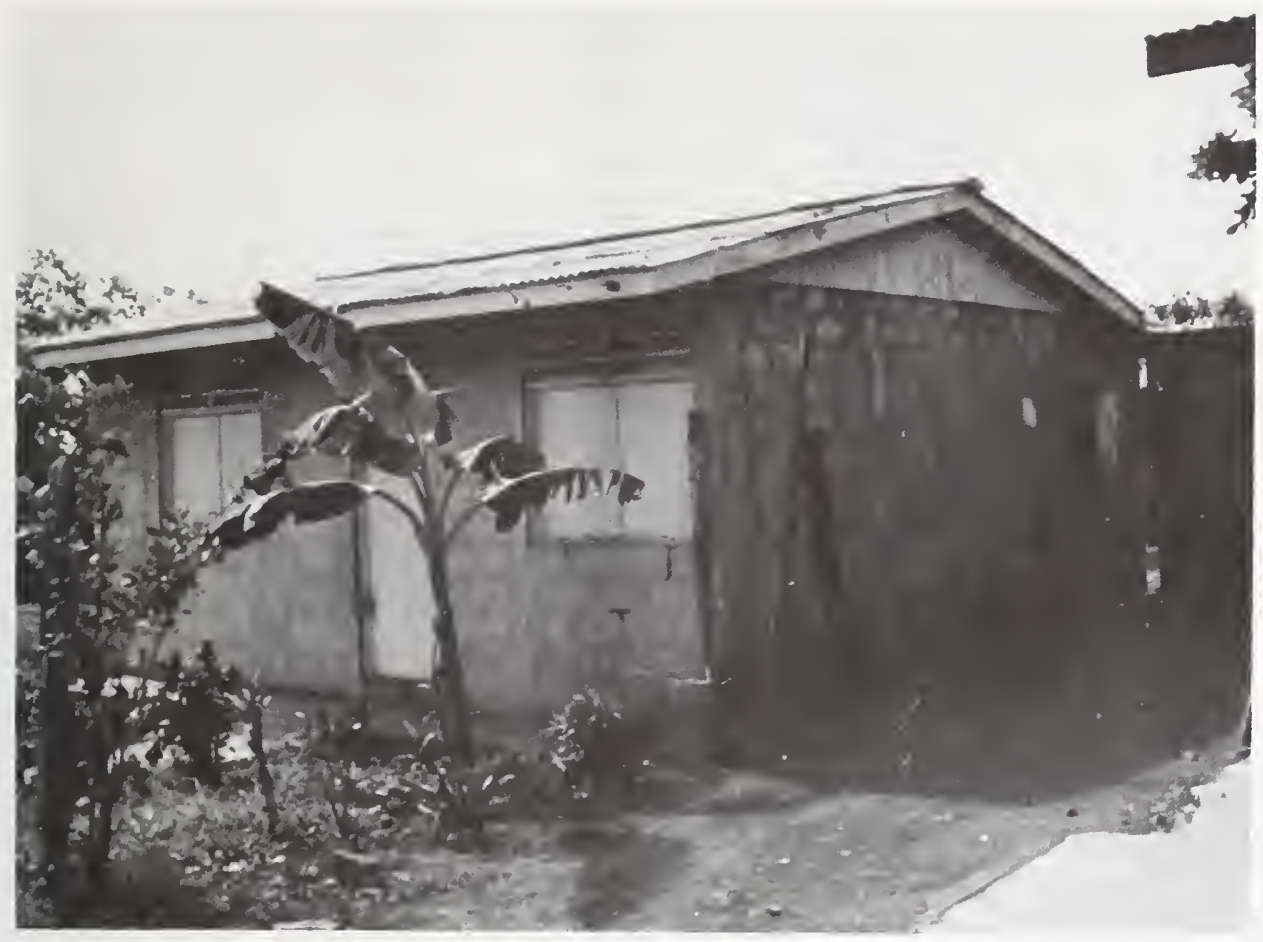

Figure 34: Colonia 14 de Septiembre, concrete block house with light damage.

Figure 35: Colonia 14 de Septiembre, cracked and repaired house of type like Maximo Jerez.

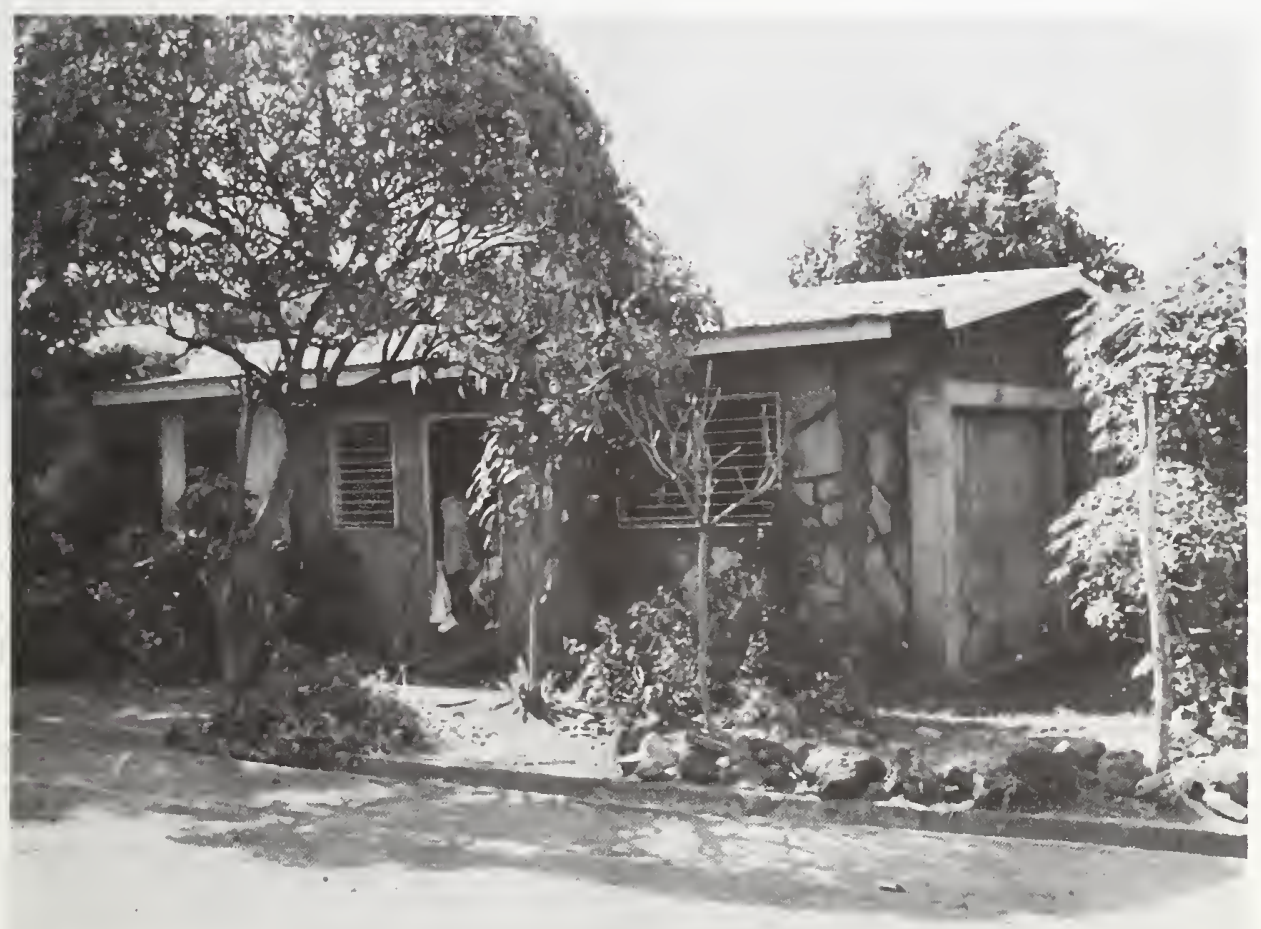




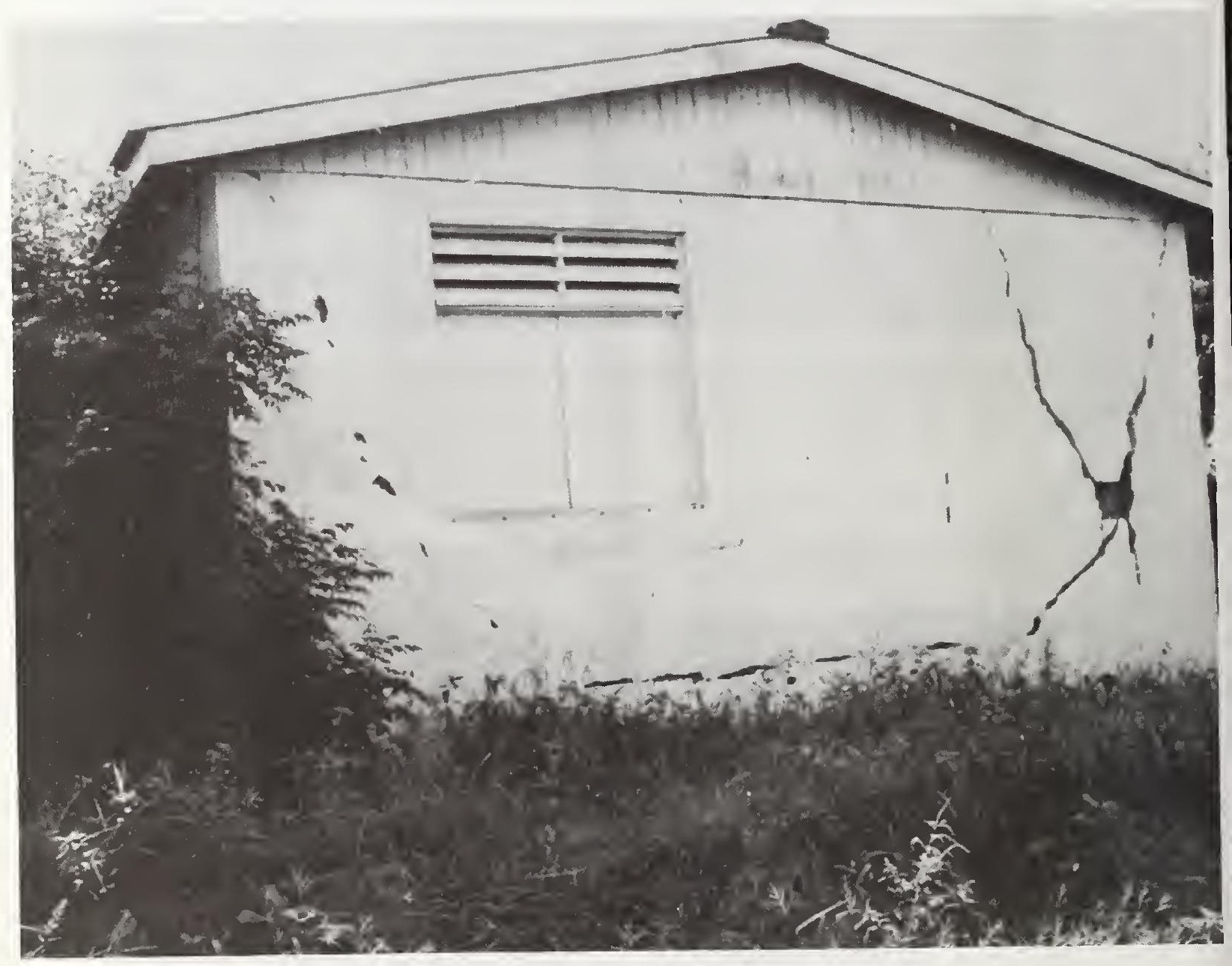

Figure 36: Colonia 14 de Septiembre, concrete block house with flexural cracking. 
Type of Housing : lower income

Size : one story

Date of Construction: under construction 1972

Financing

Location

L on figure 1

These are constructed of a system with pretensioned concrete columns imbedded in the ground through a cast-in-place footing, prestressed inverted tee beams running one way on top of the columns, large corrugation asbestos cement roof panels spanning between beams, and infill masonry walls, figure 37. Lateral force resistance comes from the imbedment of the column rather than a moment resistant connection to the beams. The earthquake shook out most of the unreinforced masonry walls; they were not anchored to beams or columns, figure 38. Many asbestos roof panels were broken by the fasteners to the beams since the connection was inadequate to cause the frames to move together. Some tee beams pulled off the columns since the beam to column connection had little strength in shear, figure 39. Human losses were limited since the units were not occupied; the system as designed seems inappropriate for regions of strong lateral force.

Housing Performance

PROYECTO PILOTO

Inspection Date: Inspected by
11 July 1973
Craig Noren
R. N. Wright
Type of Housing '? lower middle income

Size : one story and two story

Date of Construction: 1969

Financing : INVI

Location : M on figure 1

These houses [6] use light weight roofs with tile infilled and precast concrete panel walls, figures 40 and 41 . The two story houses use prestressed concrete double tees for the second floor slab and first floor ceiling. The only visible damages, even in the two-story houses, were 1 ight cracks and some trim displaced at the eaves, figure 42. The description of the project in the reference indicates that special attention was given to connection of the panels after occurrence of the 1968 earthquake.

Housing Performance

Type of Housing

Size

Date of Construction:

Financing

Location
PRIMERO DE MAYO

Inspection Date: 11 July 1973

Inspected by : Craig Noren

R. N. Wright

The row units use light corrugated asbestos roofs and reinforced concrete or masonry walls, figures 43 and 44 . There was not enough damage to clearly reveal the details of the construction. The structural performance in the earthquake was excellent. 


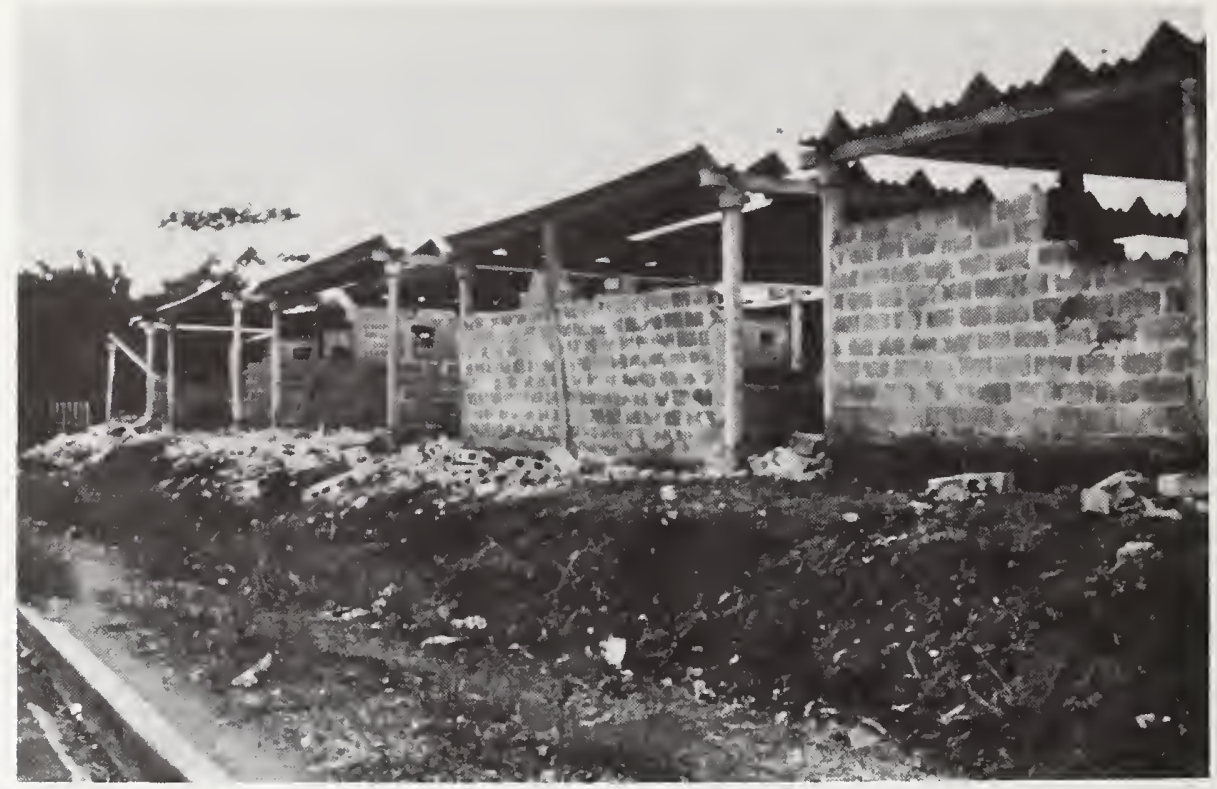

Figure 37: Viviendo de mi Hermano, frame and wall failures as seen January 3, 1973.

Figure 38: Viviendo de mi Hermano, collapsed walls.

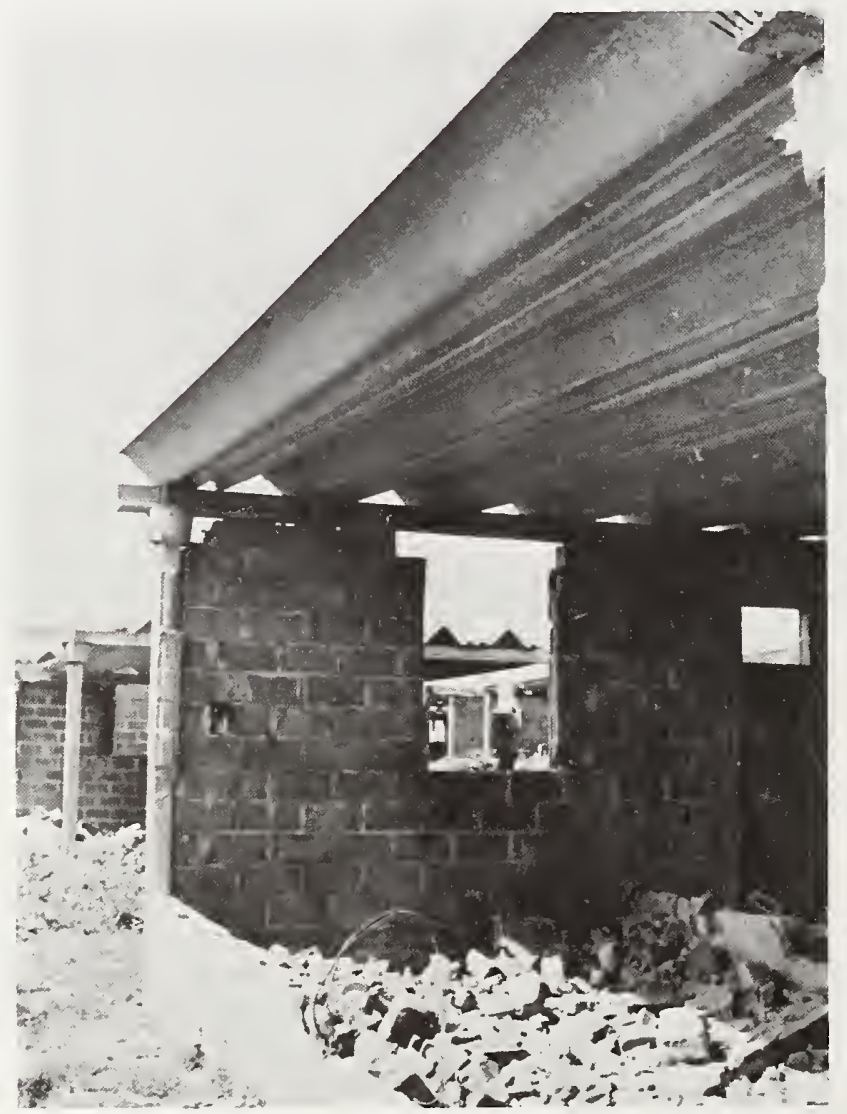




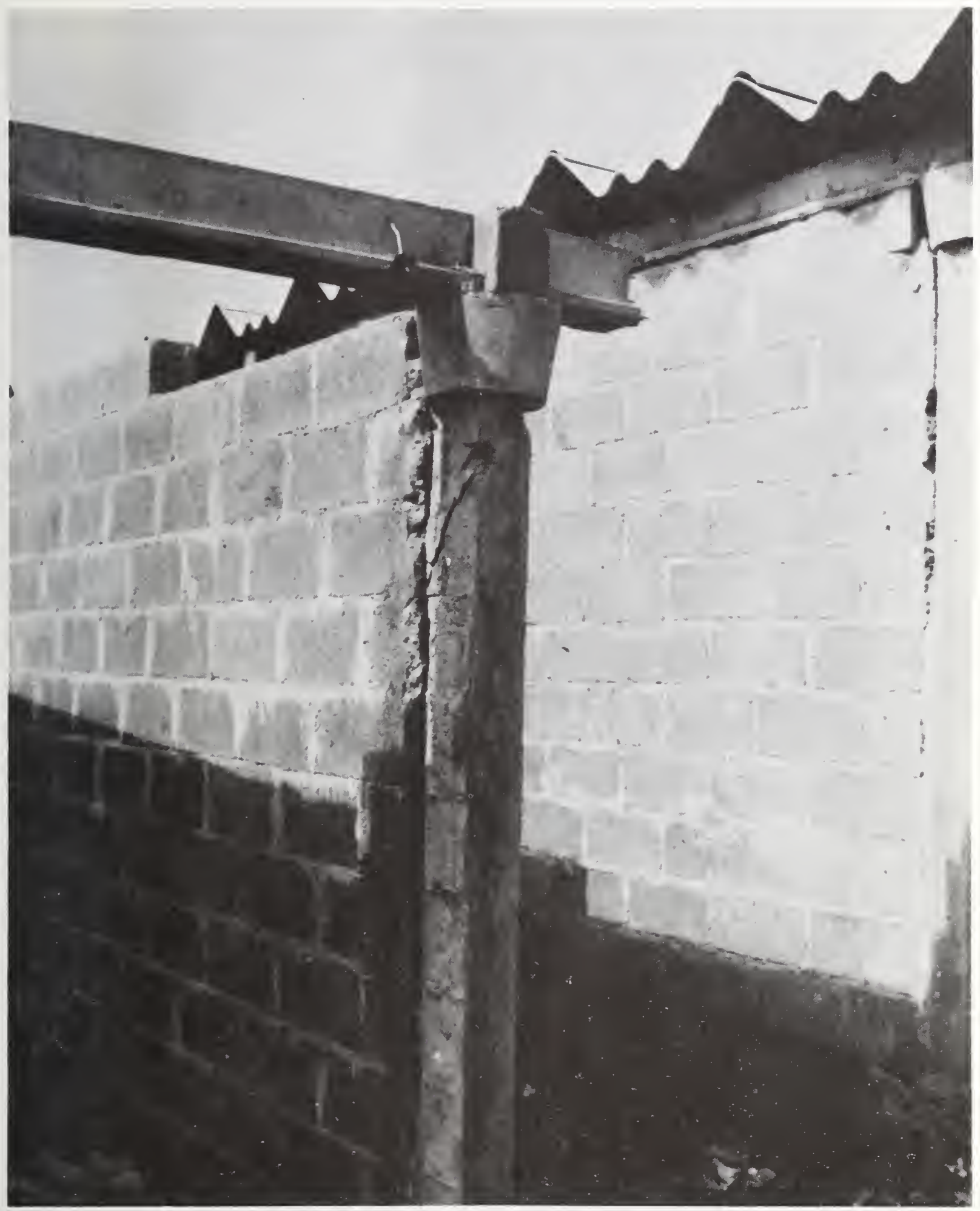

Figure 39: Viviendo de mi Hermano, sheared column. 


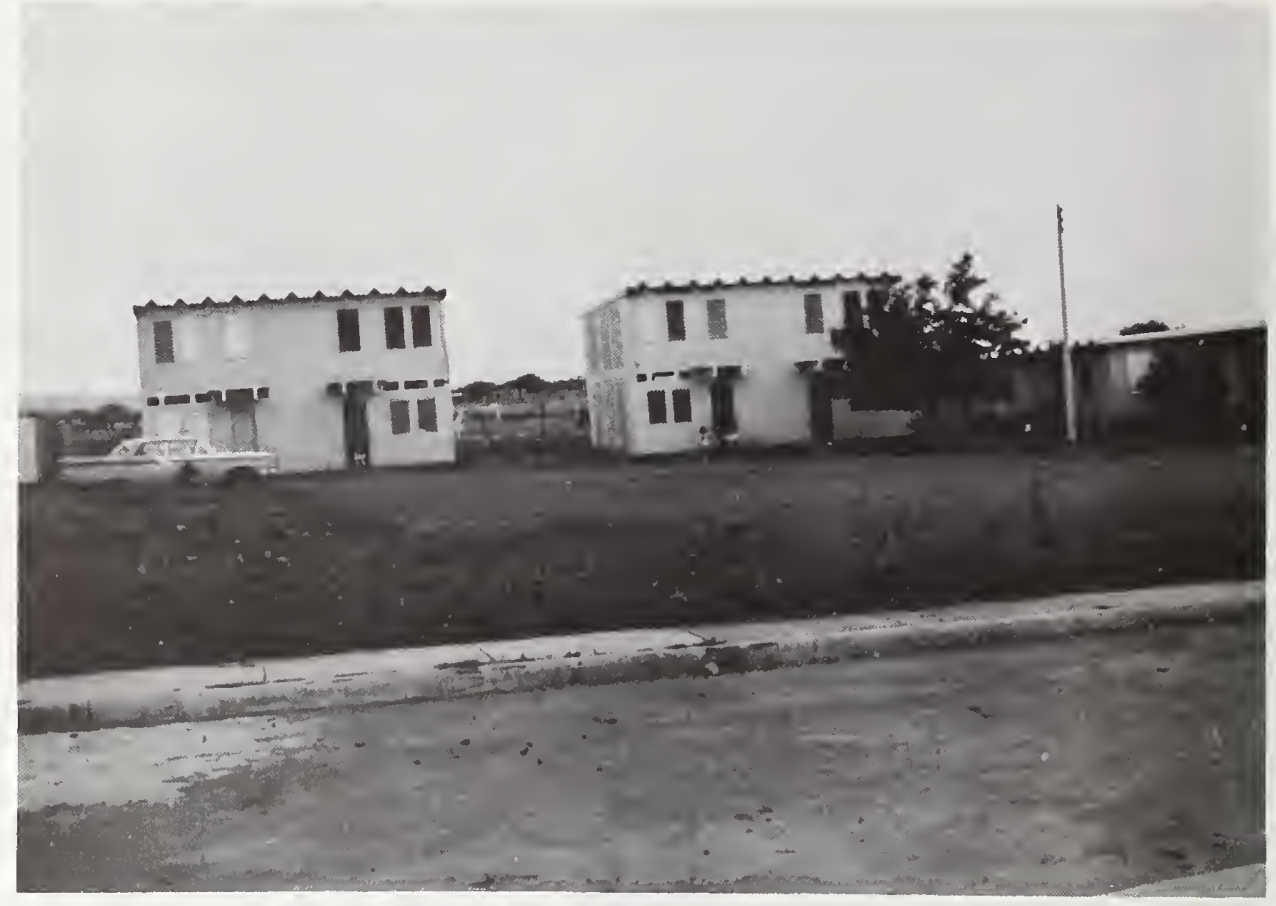

Figure 40: Proyecto Piloto, view of one and two story units.

Figure 41: Proyecto Piloto, sound structural condition of two story units.

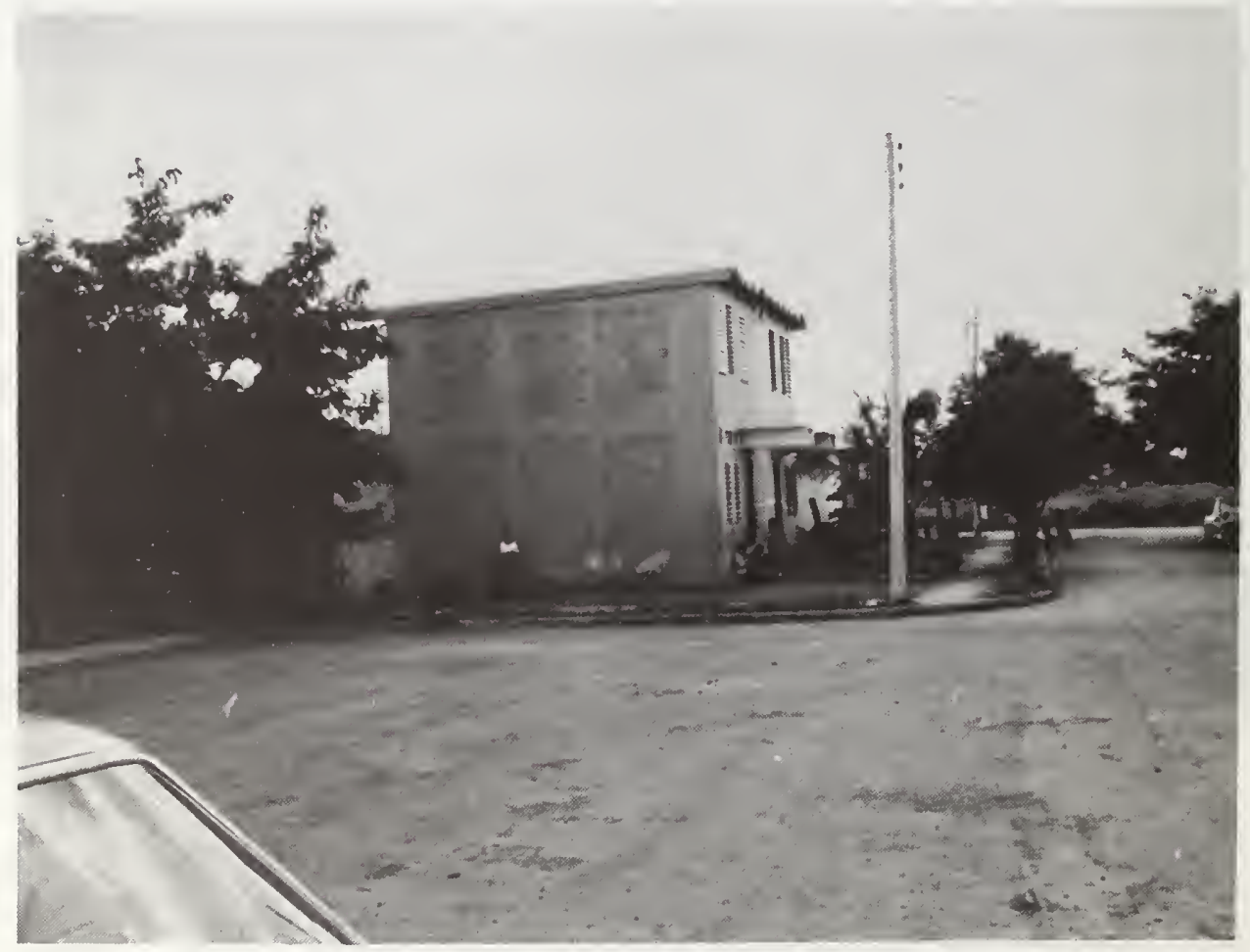




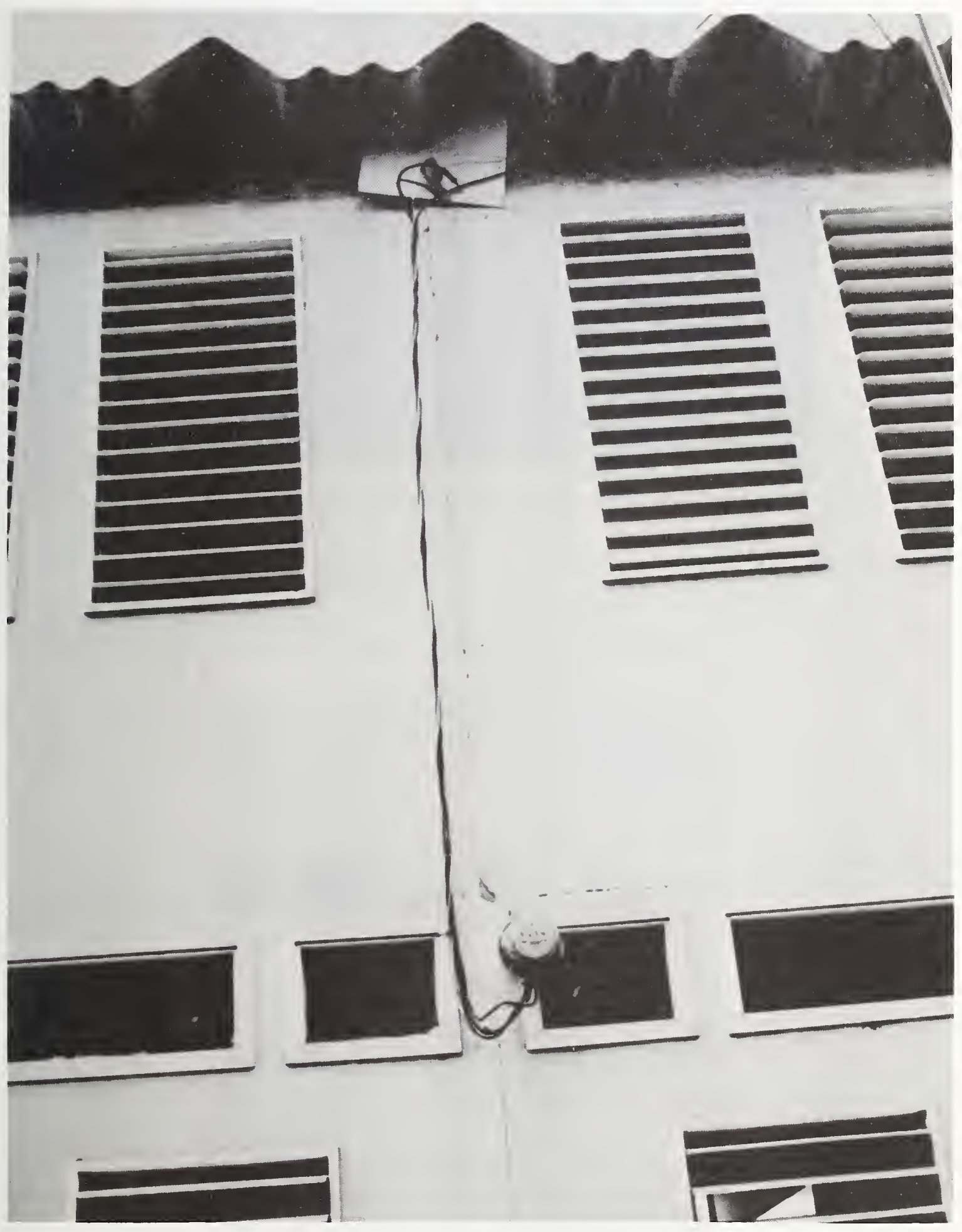

Figure 42: Proyecto Piloto, damage 1imited to loss of eave trim panels. 


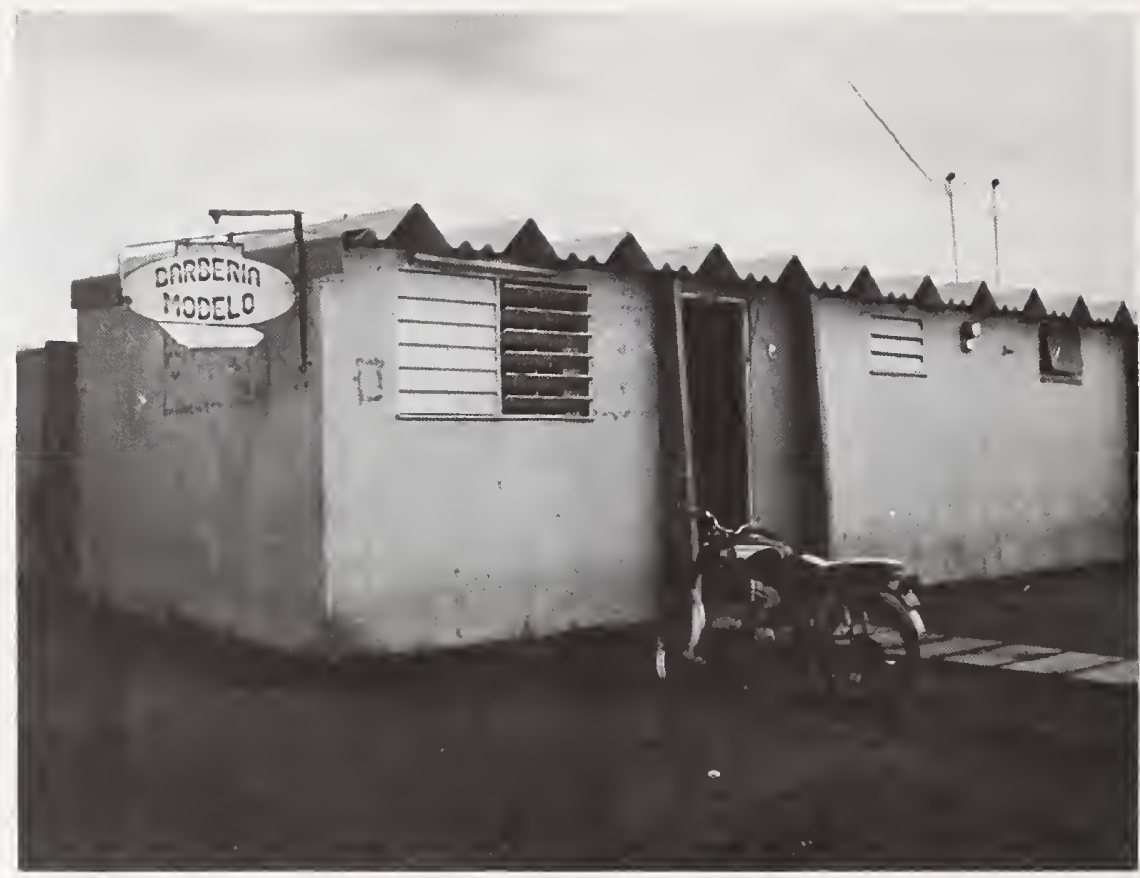

Figure 43: Primero de Mayo, units show no damage.

Figure 44: Primero de Mayo, close up of an entrance.

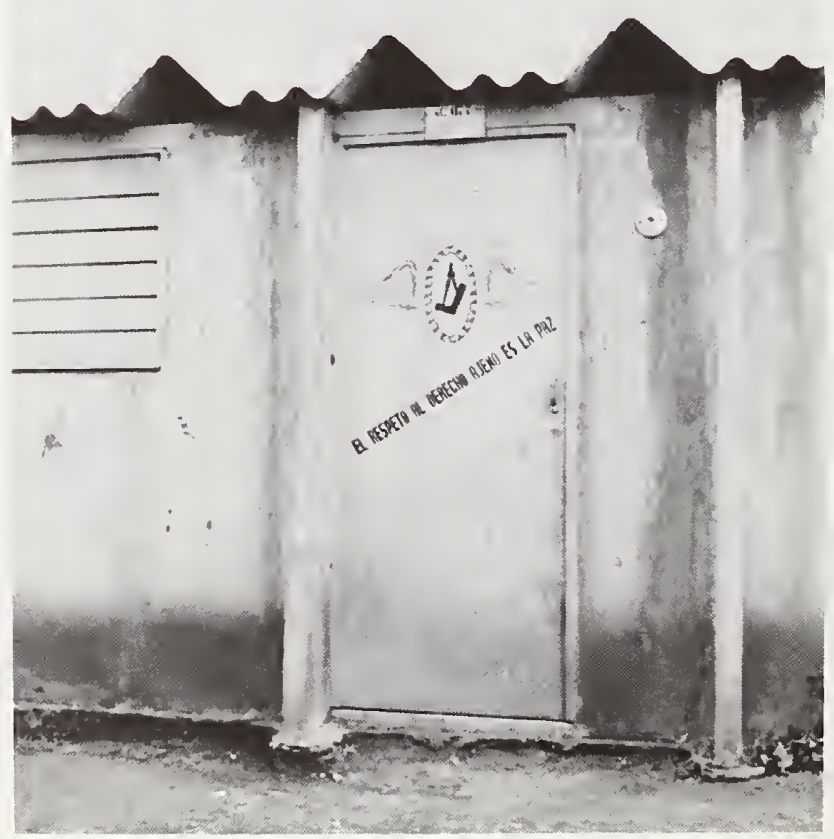


Housing Performance

Type of Housing

Size

Date of Construction:

Financing

Location
CIUDAD JARDIN

Inspection Date: 11 July 1973

Inspected by
Craig Noren

R. N. Wright

Shaking here next to the Aduana fault was strong enough to topple free standing masonry walls. These houses with light roofs and reinforced masonry walls showed no collapses; damage ranged from 1 ight to severe with most units in the lightly damaged group, figures 45 and 46 . Blocks were loosened in some walls, suggesting substandard mortar, figure 47 . 0ther walls cracked due to poor details of reinforced.

Housing Performance

Type of Housing : middle income

Size : one story

Date of Construction: 1969

Financing : CABEI

Location : P on figure 1
BELLO HORIZONTE

Inspection Date: 30 Dec. 1972

Inspected by : Raul Amador

Sam Kramer

R. N. Wright

These are single and duplex units with cast-in-place reinforced concrete walls and precast prestressed channel shaped roof panels, figure 48 . Dwe11ing units are approximately $20 \mathrm{ft}$ wide by $40 \mathrm{ft}$ deep, walls are 4 in thick, roof panels are $8 \mathrm{ft}$ wide and $22 \mathrm{ft}$ long with $12 \mathrm{in}$ flange height and $21 / 2$ in slab thickness. Roof panels are intended to be attached to walls by welding at four corner pads. At best, weld size was about $3 / 16$ in, 2 in in total length; many welds were spots or omitted, figure 49 . In most units roof panels broke their anchorage and moved, sometimes enough to fall off the wall and into the unit, figure 50. Where welds were stronger the wall or slab often is broken around the anchorage of its connection pad, figure 51. Other damages to the walls were slight.

These show graphically how a basically sound precast system can fail through inadequate connections. 


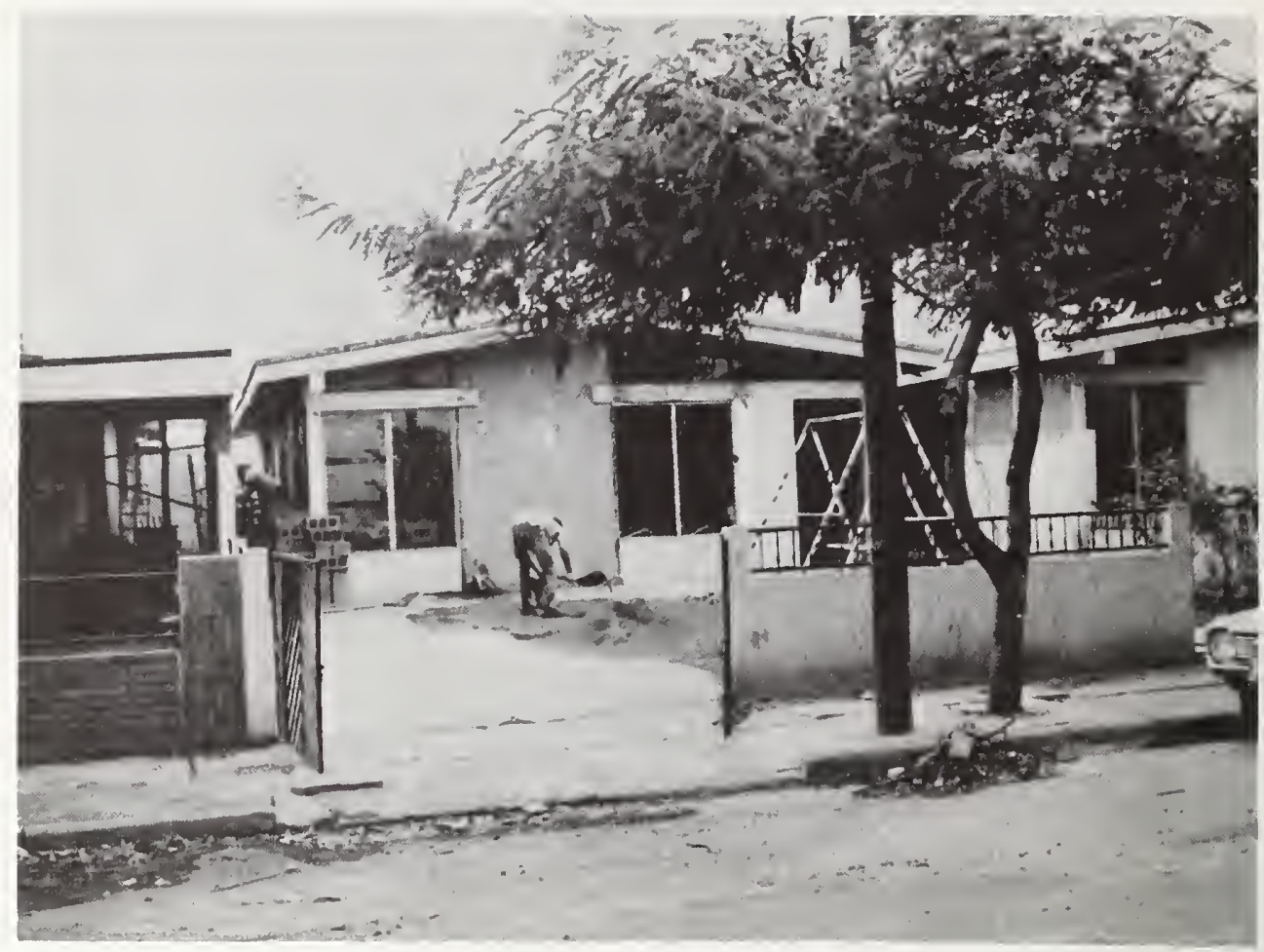

Figure 45: Ciudad Jardin, repairs of cracking and broken panels.

Figure 46: Ciudad Jardin, localized damage, failure of free standing walls.

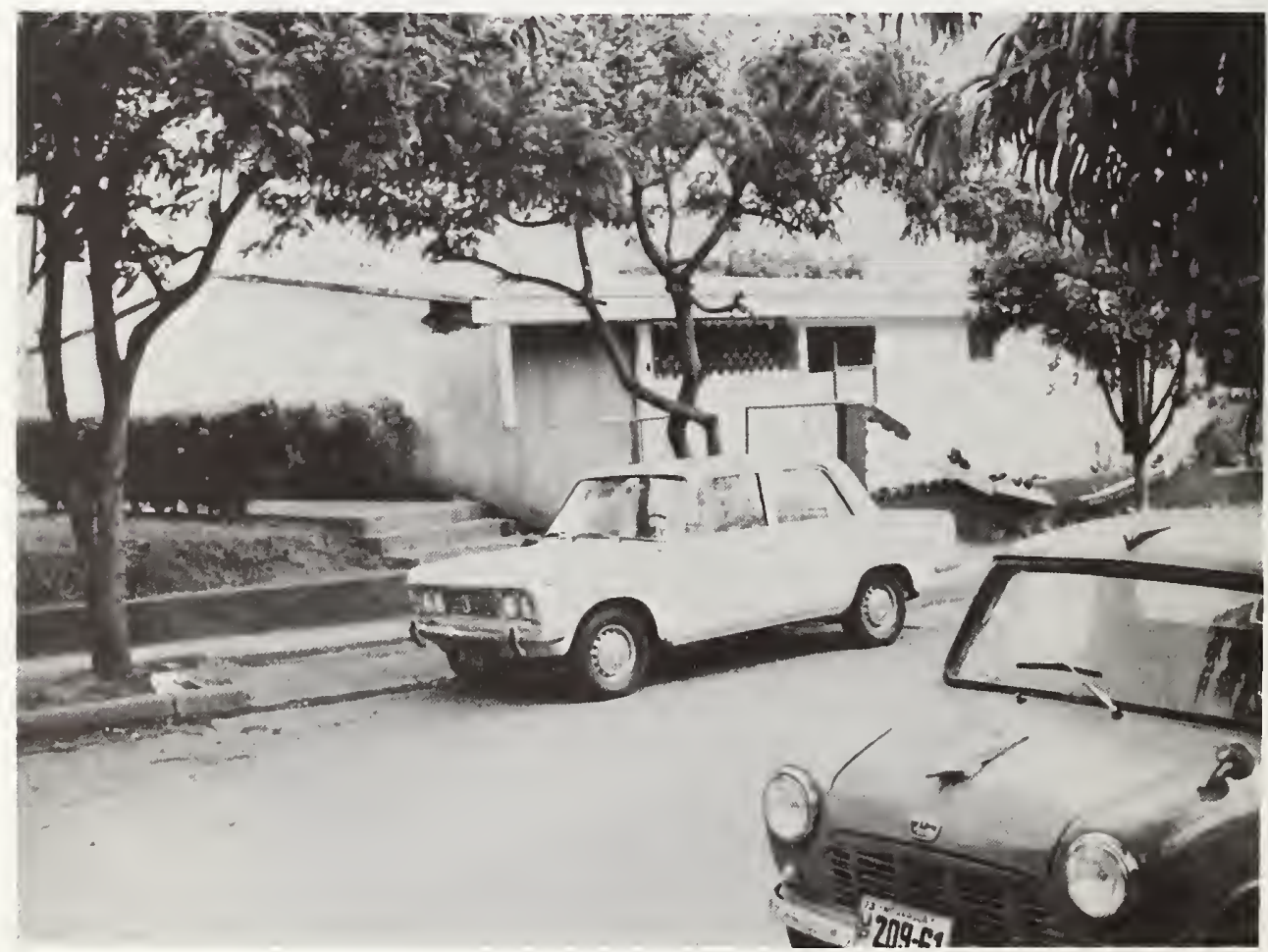




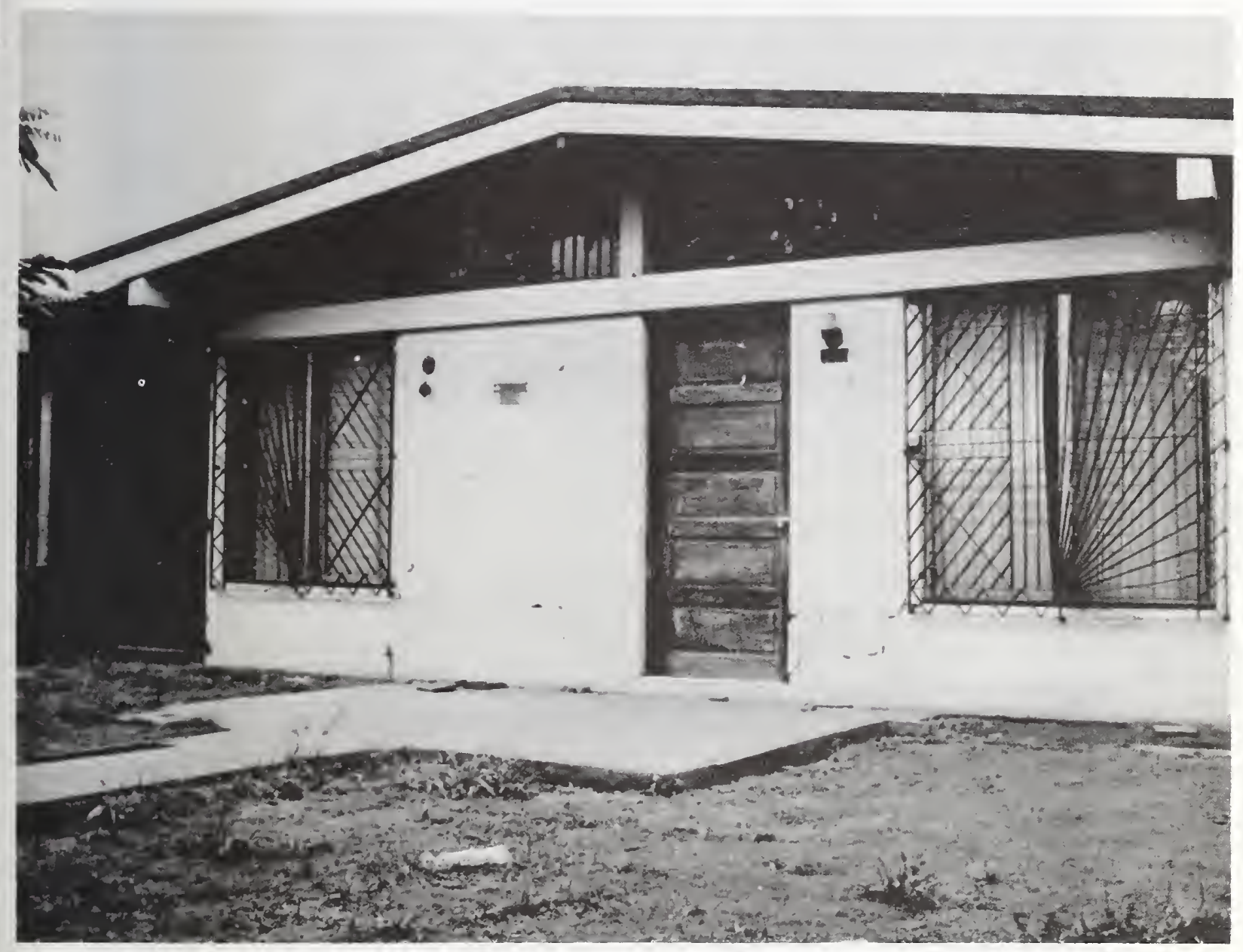

Figure 47: Ciudad Jardin, crack patterns suggesting weak mortar. 


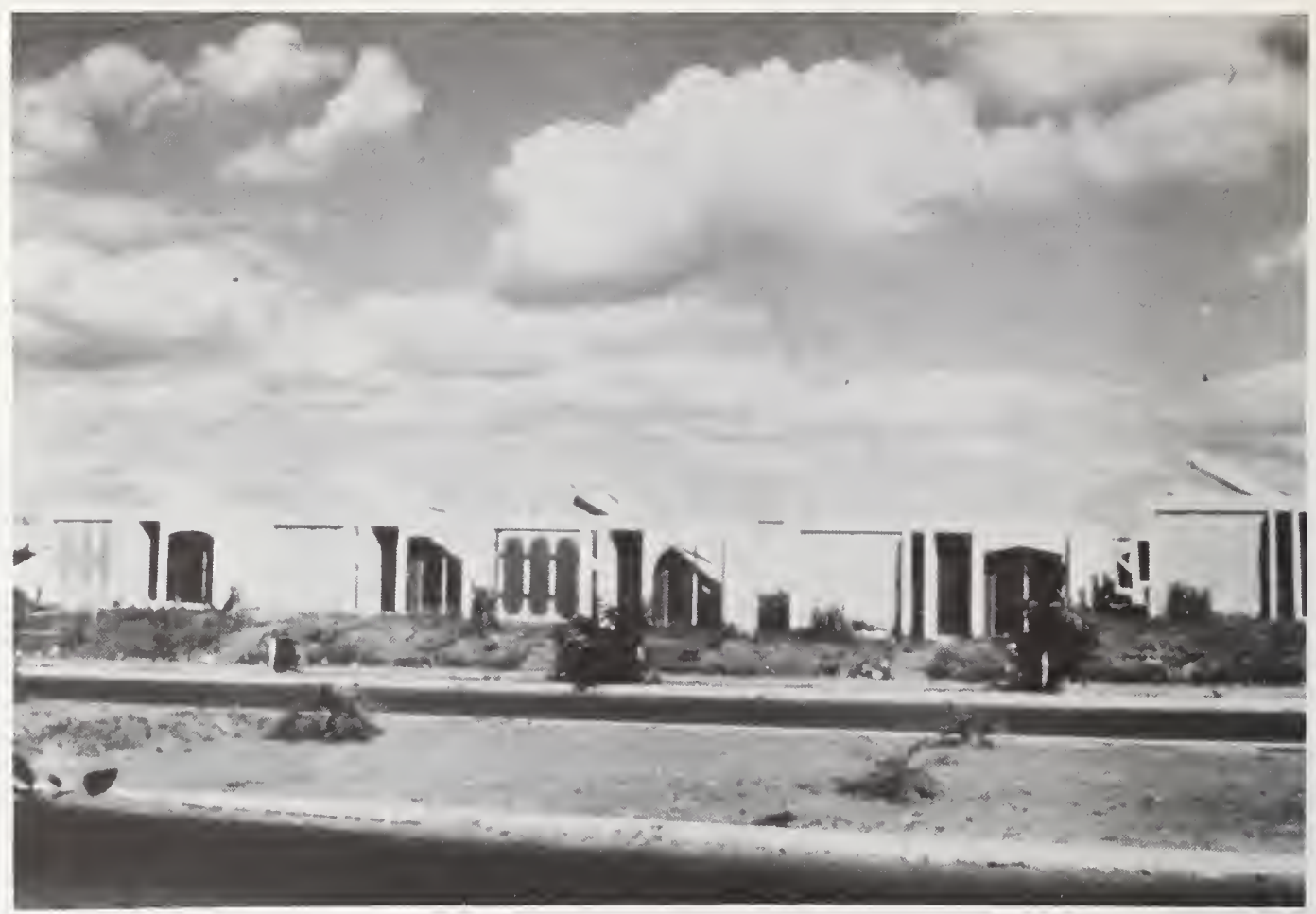

Figure 48: Bello Horizonte, the precast roof channels have slid off walls, December 30, 1972.

Figure 49: Bello Horizonte, lack of connection of roof to wall in duplex unit, December 30, 1972.

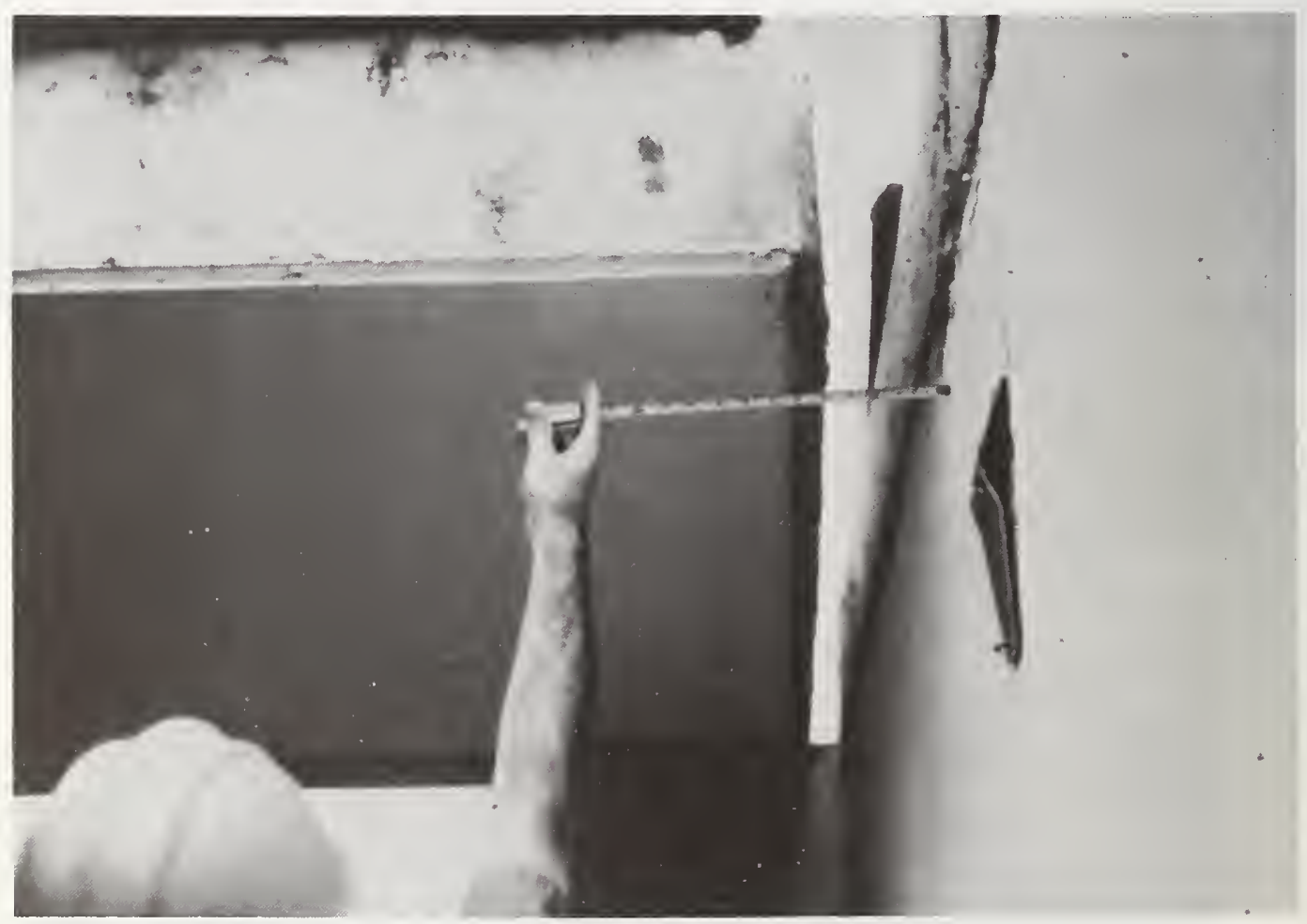




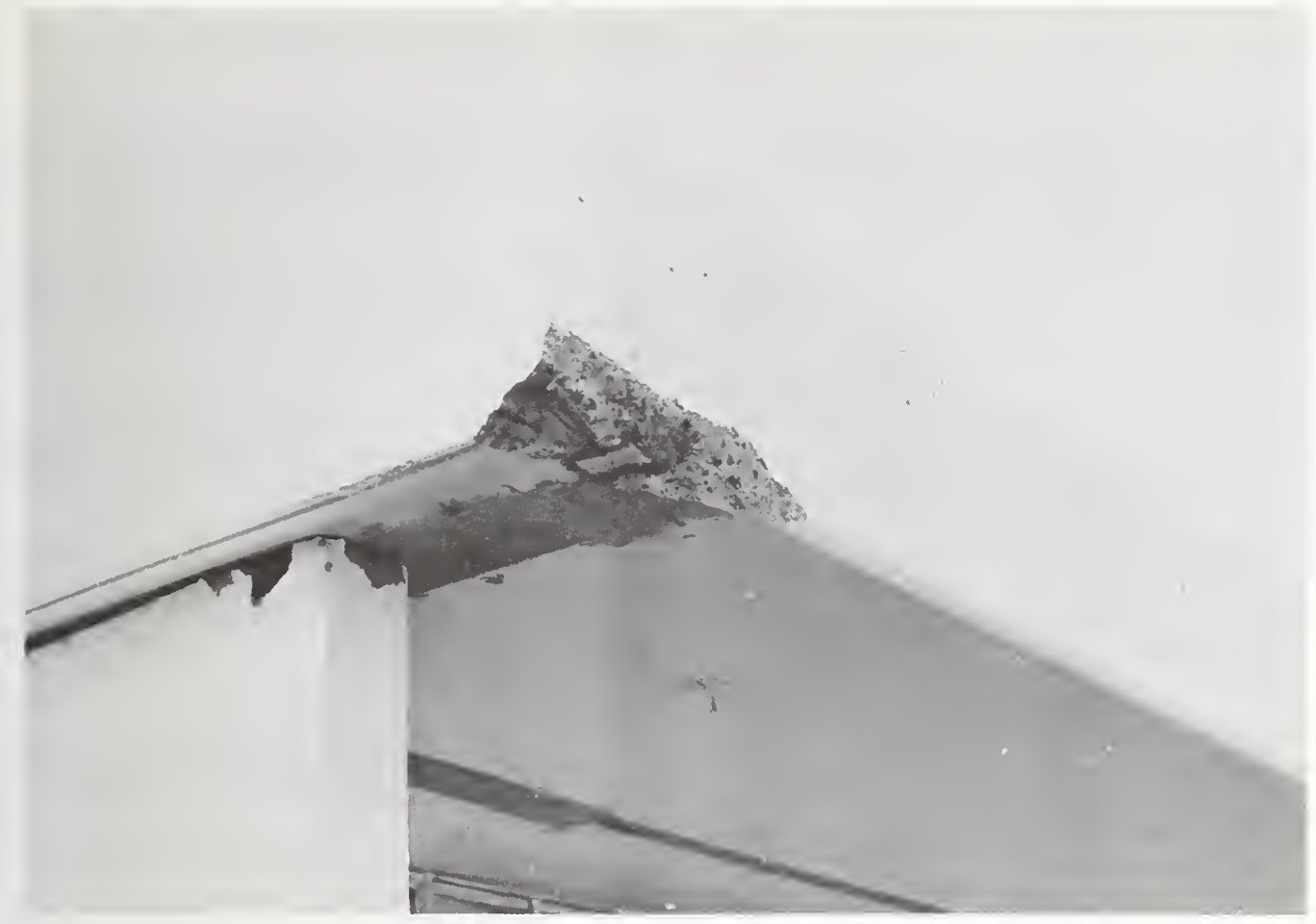

Figure 50: Bello Horizonte, weld broken and roof panel cracked at connection, December 30, 1972.

Figure 51: Bello Horizonte, walls cracked at connection of roof panels, December 30, 1972.

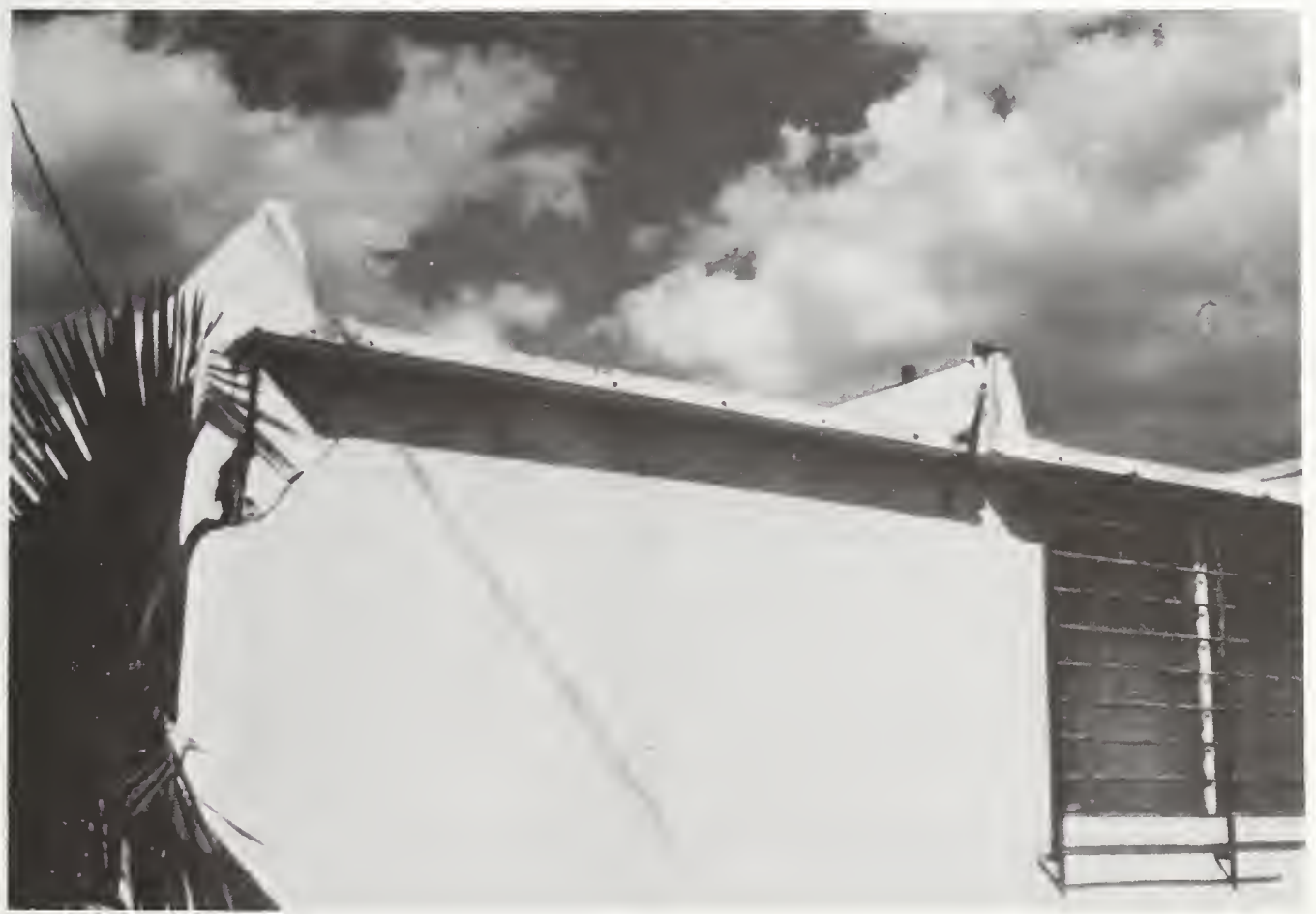


[1] Wright, R. N., and Kramer, S., Building Performance in the 1972 Managua Earthquake, National Bureau of Standards (U.S.), Technical Note 807,150 pages (1973).

[2] Matthiesen, R. B., and Knudson, C. F., Strong-Motion Instrumental Measurements, Managua, Nicaragua Earthquake of December 23, 1972, Earthquake Engineering Research Institute, pp. 21-25 (May 1973).

[3] Lew, H. S., Leyendecker, E. V., and Dikkers, R. D., Engineering Aspects of the 1971 San Fernando Earthquake, National Bureau of Standards (U.S.) Building Science Series 40, 419 pages (December 1971).

[4] Brown, R. D., Jr., Ward, P. L., and Plafker, G., Geologic and Seismologic Aspects of the Managua, Nicaragua Earthquake of December 23, 1972 , U.S. Geological Survey, Geological Survey, Professional Paper 838,34 pages (1973).

[5] Hansen, Francisco, and Chavez, Victor M., "Isoseismal Maps of the Managua, December 23, 1972 Earthquake, "Managua Nicaraguan Earthquake of December 23, 1972, Earthquake Engineering Research Institute, San Francisco, pp. 104-114 (November 1973).

[6] Colonia Managua, Ideas and Methods Exchange No. 58, Office of International Affairs, Department of Housing and Urban Development, Washington, D. C., 15 pages (June 1962).

[7] Proyecto Piloto de Vivienda en el Istmo Centroamericano, Comite Interinstitucional sobre Vivienda y Desarrollo Urbano, Secretaria General de la Organizacion de los Estados Americanos, Washington, D. C., 65 pages (1972). 


\begin{tabular}{|c|c|c|c|}
\hline $\begin{array}{l}\text { U.S. DEPT. OF COMM. } \\
\text { BIBLIOGRAPHIC DATA } \\
\text { SHEET }\end{array}$ & $\begin{array}{l}\text { 1. PUBLICATION OR REPORT NO. } \\
\text { NBS TN- } 885\end{array}$ & $\begin{array}{l}\text { 2. Gov't Accession } \\
\text { No. }\end{array}$ & 3. Recipient's Accession No. \\
\hline \multirow{2}{*}{\multicolumn{3}{|c|}{$\begin{array}{l}\text { 4. TITLE AND SUBTITLE } \\
\text { A Technical Review of the Nicaraguan Building } \\
\text { Regulatory System }\end{array}$}} & $\begin{array}{r}\text { 5. Publication Date } \\
\text { October } 1975\end{array}$ \\
\hline & & & 6. Performing Organization Code \\
\hline \multicolumn{3}{|c|}{$\begin{array}{l}\text { 7. AUTHOR(S) } \\
\text { Richard N. Wright, and Ing. Atilano Lamana }\end{array}$} & 8. Performing Organ. Report No. \\
\hline \multirow{2}{*}{\multicolumn{3}{|c|}{$\begin{array}{l}\text { 9. PERFORMING ORGANIZATION NAME AND ADDRESS } \\
\text { NATIONAL BUREAU OF STANDARDS } \\
\text { DEPARTMENT OF COMMERCE } \\
\text { WASHINGTON, D.C. } 20234\end{array}$}} & $\begin{array}{l}\text { 10. Project/Task/Work Unit No. } \\
460.00\end{array}$ \\
\hline & & & 11. Contract/Grant No. \\
\hline \multirow{3}{*}{\multicolumn{3}{|c|}{$\begin{array}{l}\text { 12. Sponsoring Otganization Name and Complete Address (Street, City, State, ZIP) } \\
\text { National Bureau of Standards } \\
\text { Organization of American States } \\
\text { Agency for Internationa1 Development } \\
\text { (Department of State) }\end{array}$}} & $\begin{array}{l}\text { 13. Type of Report \& Period } \\
\text { Covered }\end{array}$ \\
\hline & & & Final \\
\hline & & & 14. Sponsoring Agency Code \\
\hline
\end{tabular}

15. SUPPLEMENTARY NOTES

Library of Congress Catalog Card Number: 75-600078

16. ABSTRACT (A 200-word or less factual summary of most significant information. If document includes a significant bibliography or literature survey, mention it here.)

This report on the Nicaraguan Building Regulatory System has been prepared under the auspices of the Organization of American States and the United States Agency for International Development. It presents an overview of the building regulatory system in Nicaragua; its activities in review of designs, issuance of building permits, inspection of construction, control of quality of materials, and issuance of occupancy permits. The technical bases for these activities are the building code and standards, the laboratory facilities for control of the quality of building materials, and the processes for development and application of codes and standards. Recommendations address the status and development of this system and its technical bases.

The losses in the December 23, 1972, Managua Earthquake provided dramatic evidence of the need for effective implementation of good building standards. Repetitions of these tragic losses elsewhere in Nicaragua and in a reconstructed Managua are certain unless a good building code is developed and adopted, its use and design by architects and engineers enforced by careful review of designs, and the implementation of these designs by the builders assured by inspection of construction and testing of building materials. A summary and critical review of U.S. building regulatory practices for areas with severe natural hazards is presented in Appendix B for guidance in building regulatory system planning and development. A survey of housing performance in Managua is presented in Appendix C to illustrate that earthquake resistant construction is feasible and economical for Nicaragua and other nations with comparable resources.

17. KEY WORDS (six to twelve entries; alphabetical order; capitalize only the first letter of the first key word unless a proper name; separated by semicolons)

Architecture; building; building codes; building design; disaster mitigation; earthquakes; engineering; environmental hazards; housing; inspection and testing; safety.

$$
\text { 18 }
$$

AVAILABILITY

X Unlimited

$\square$ For Official Distribution. Do Not Release to NTIS

X) Order From Sup. of Doc., U.S. Government Printing Office Wa shington, D.C. 20402 , SD Cat. No. C13.46:885

$\square$ Order From National Technical Information Service (NTIS) Springfield, Virginia 22151
19. SECURITY CLASS (THIS REPURT)

UNCL ASSIF IED

20. SECURITY CLASS (THIS PAGE)
21. NO. OF PAGES

85

22. Price

$\$ 1.45$

UNCLASSIFIED 



\section{gestand \\ 28 e $e^{8} \times$}

0 $e^{\circ}$

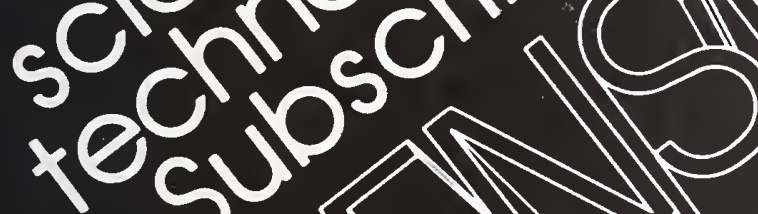
+esu
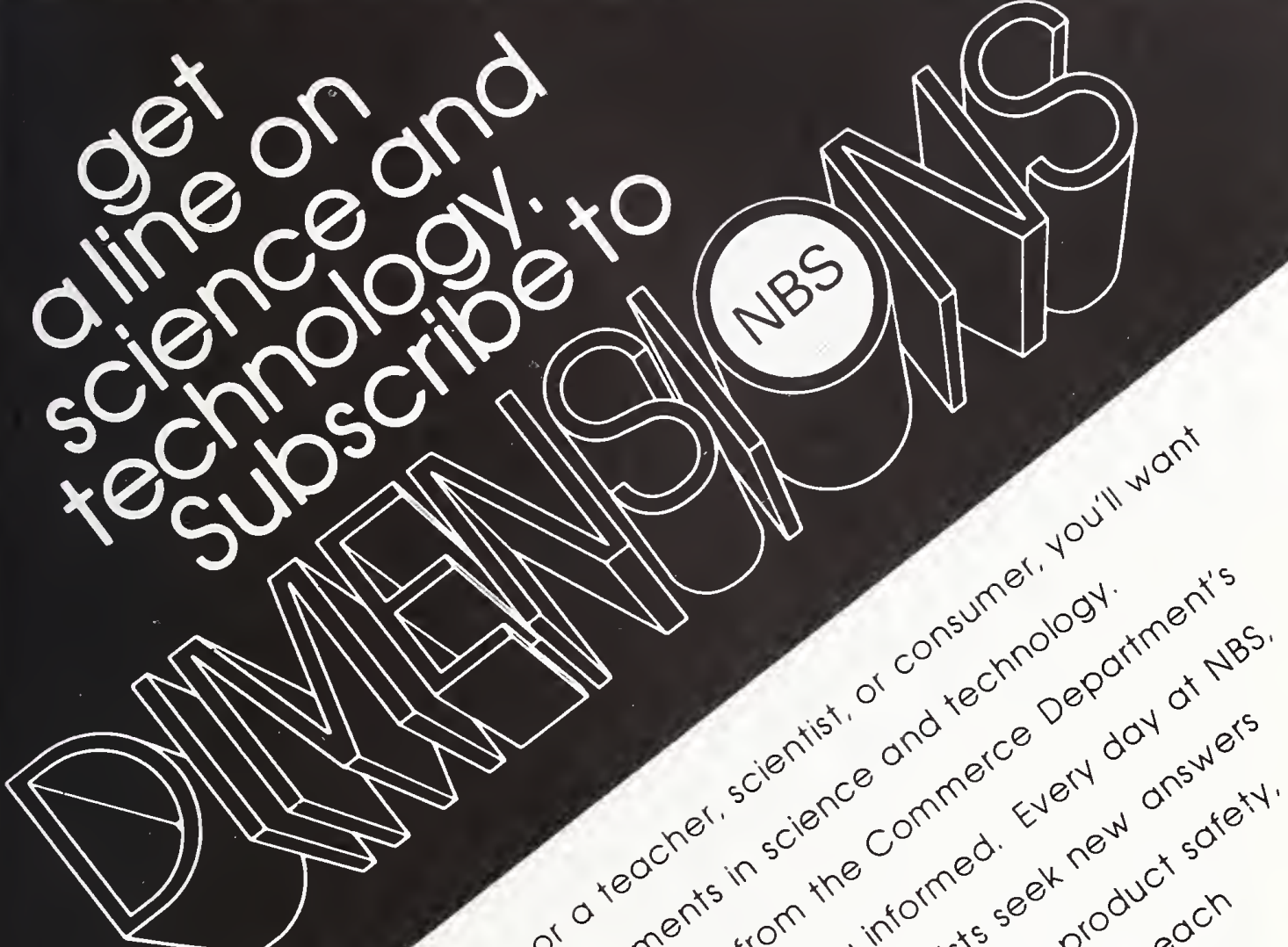

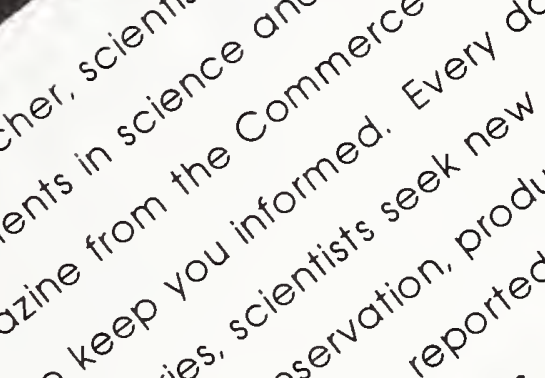

when

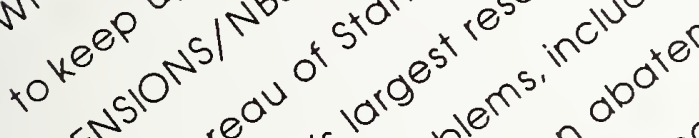

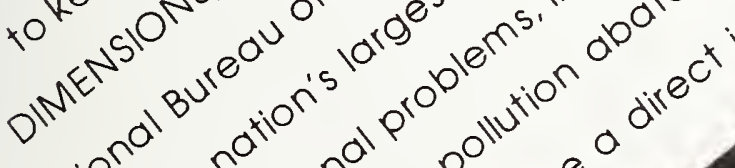

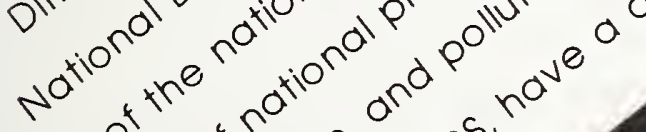

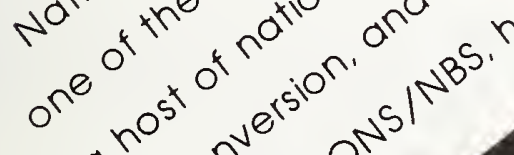

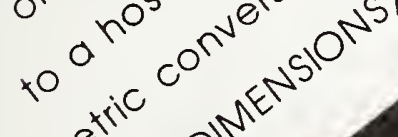

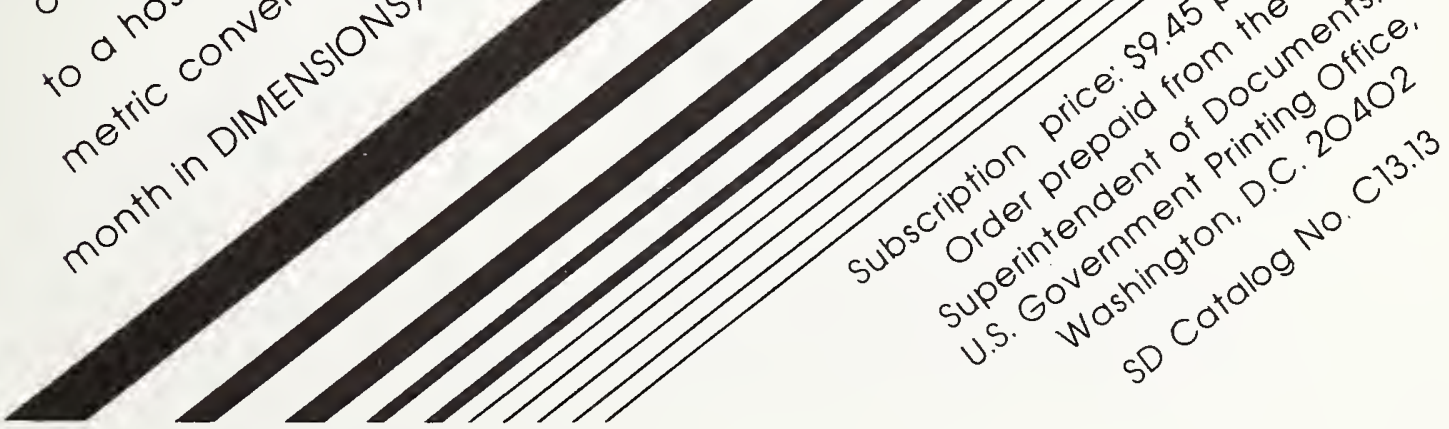





\section{NBS TECHNICAL PUBLICATIONS}

\section{PERIODICALS}

JOURNAL OF RESEARCH reports National Bureau of Standards research and development in physics, mathematics, and chemistry. It is published in two sections, available separately:

- Physics and Chemistry (Section A)

Papers of interest primarily to scientists working in these fields. This section covers a broad range of physical and chemical research, with major emphasis on standards of physical measurement, fundamental constants, and properties of matter. Issued six times a year. Annual subscription: Domestic, $\$ 17.00$; Foreign, $\$ 21.25$.

\section{- Mathematical Sciences (Section B)}

Studies and compilations designed mainly for the mathematician and theoretical physicist. Topics in mathematical statistics, theory of experiment design, numerical analysis, theoretical physics and chemistry, logical design and programming of computers and computer systems. Short numerical tables. Issued quarterly. Annual subscription: Domestic, $\$ 9.00$; Foreign, $\$ 11.25$

DIMENSIONS/NBS (formerly Technical News Bulletin)-This monthly magazine is published to inform scientists, engineers, businessmen, industry, teachers, students, and consumers of the latest advances in science and technology, with primary emphasis on the work at NBS. The magazine highlights and reviews such issues as energy research, fire protection, building technology, metric conversion, pollution abatement, health and safety, and consumer product performance. In addition, it reports the results of Bureau programs in measurement standards and techniques, properties of matter and materials, engineering standards and services, instrumentation, and automatic data processing.

Annual subscription: Domestic, $\$ 9.45$; Foreign, $\$ 11.85$.

\section{NONPERIODICALS}

Monographs-Major contributions to the technical literature on various subjects related to the Bureau's scientific and technical activities.

Handbooks-Recommended codes of engineering and industrial practice (including safety codes) developed in cooperation with interested industries, professional organizations, and regulatory bodies.

Special Publications-Include proceedings of conferences sponsored by NBS, NBS annual reports, and other special publications appropriate to this grouping such as wall charts, pocket cards, and bibliographies.

Applied Mathematics Series-Mathematical tables, manuals, and studies of special interest to physicists, engineers, chemists, biologists, mathematicians, computer programmers, and others engaged in scientific and technical work.

National Standard Reference Data Series-Provides quantitative data on the physical and chemical properties of materials, compiled from the world's literature and critically evaluated. Developed under a world-wide program coordinated by NBS. Program under authority of National Standard Data Act (Public Law 90-396).

NOTE: At present the principal publication outlet for these data is the Journal of Physical and Chemical Reference Data (JPCRD) published quarterly for NBS by the American Chemical Society (ACS) and the American Institute of Physics (AIP). Subscriptions, reprints, and supplements available from ACS, 1155 Sixteenth St. N. W., Wash. D. C. 20056.

Building Science Series-Disseminates technical information developed at the Bureau on building materials, components, systems, and whole structures. The series presents research results, test methods, and performance criteria related to the structural and environmental functions and the durability and safety characteristics of building elements and systems.

Technical Notes-Studies or reports which are complete in themselves but restrictive in their treatment of a subject. Analogous to monographs but not so compre. hensive in scope or definitive in treatment of the subject area. Often serve as a vehicle for final reports of work performed at NBS under the sponsorship of other government agencies.

Voluntary Product Standards-Developed under procedures published by the Department of Commerce in Part 10, Title 15, of the Code of Federal Regulations. The purpose of the standards is to establish nationally recognized requirements for products, and to provide all concerned interests with a basis for common understanding of the characteristics of the products. NBS administers this program as a supplement to the activities of the private sector standardizing organizations.

Federal Information Processing Standards Publications (FIPS PUBS)-Publications in this series collectively constitute the Federal Information Processing Standards Register. Register serves as the official source of information in the Federal Government regarding standards issued by NBS pursuant to the Federal Property and Administrative Services Act of 1949 as amended, Public Law 89-306 (79 Stat. 1127), and as implemented by Executive Order 11717 (38 FR 12315, dated May 11, 1973) and Part 6 of Title 15 CFR (Code of Federal Regulations).

Consumer Information Series-Practical information, based on NBS research and experience, covering areas of interest to the consumer. Easily understandable language and illustrations provide useful background knowledge for shopping in today's technological marketplace.

NBS Interagency Reports (NBSIR)-A special series of interim or final reports on work performed by NBS for outside sponsors (both government and non-government). In general, initial distribution is handled by the sponsor; public distribution is by the National Technical Information Service (Springfield, Va. 22161) in paper copy or microfiche form.

Order NBS publications (except NBSIR's and Bibliographic Subscription Services) from: Superintendent of Documents, Government Printing Office, Washington, D.C. 20402 .

\section{BIBLIOGRAPHIC SUBSCRIPTION SERVICES}

The following current-awareness and literature-survey bibliographies are issued periodically by the Bureau: Cryogenic Data Center Current Awareness Service

A literature survey issued biweekly. Annual subscription: Domestic, $\$ 20.00$; foreign, $\$ 25.00$.

Liquefied Natural Gas. A literature survey issued quarterly. Annual subscription: $\$ 20.00$.

Superconducting Devices and Materials. A literature survey issued quarterly. Annual subscription: $\$ 20.00$. Send subscription orders and remittances for the preceding bibliographic services to National Technical Information Service, Springfield, Va, 22161.

Electromagnetic Metrology Current Awareness Service Issued monthly. Annual subscription: $\$ 100.00$ (Special rates for multi-subscriptions). Send subscription order and remittance to Electromagnetics Division, National Bureau of Standards, Boulder, Colo. 80302 
U.S. DEPARTMENT OF COMMERCE

National Bureau of Standards

Washington, D.C. 20234

POSTAGE AND FEES PAIO

U.S. OEPARTMENT OF COMMERCE $C O M=215$

OFFICIAL BUSINESS

Penalty for Private Use, $\$ 300$
SPECIAL FOURTH-CLASS RATE BOOK 